DEPARTMENT OF THE INTERIOR

UNITED STATES GEOLOGICAL STRVEY

CHARLES D. WALCOTT, DIRECTOR

\title{
FIELD ASSAY OF WATER
}

BY

MARSHALL O. LEIGHTON

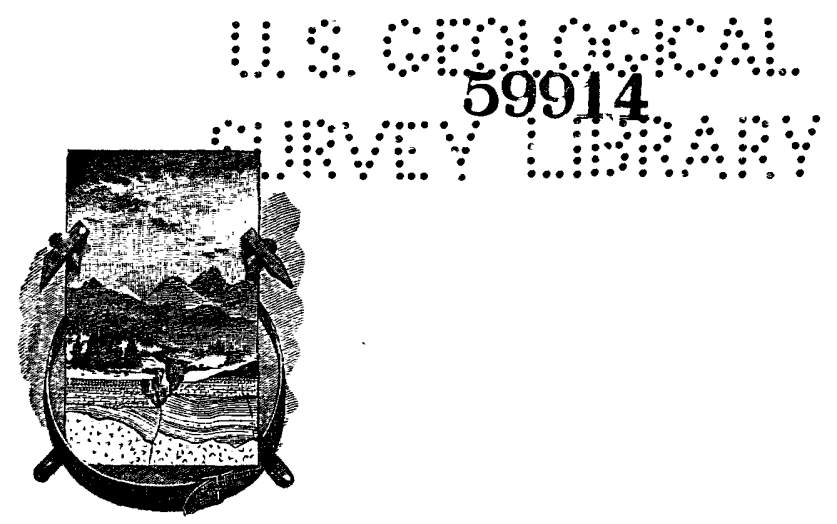

WA SHIN G TON

GOVERNMENTRINTING OFFIOE

1905 
Aromenten

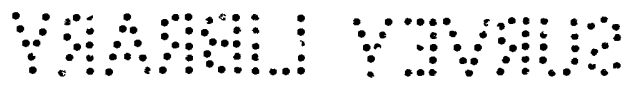




\section{O N T E N TS.}

cetter of transmittal

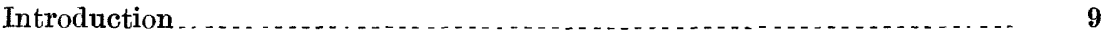

Sanitary analyses....

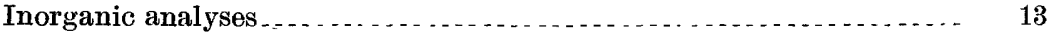

General observations ............ 15

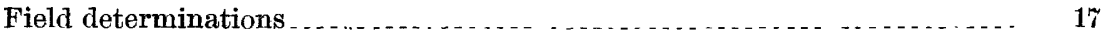

Suspended matter . . . . . . . .

Methods of determination $\ldots$

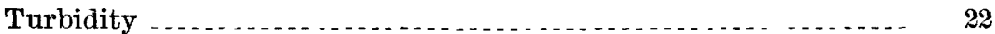

United States Geological Survey turbidity $\operatorname{rod} \ldots \ldots \ldots \ldots \ldots . . . . .233$

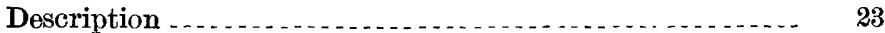

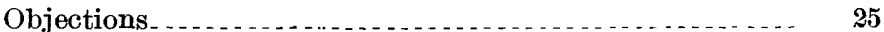

Jackson's turbidimeter. . . . . . . . . .

Description $\ldots \ldots \ldots \ldots . \ldots 26$

Tests ... . . .

Probable error $\ldots \ldots \ldots \ldots$

Color ....

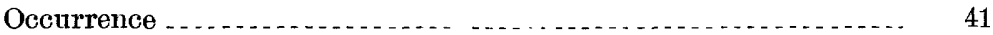

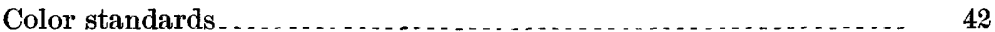

Geological Survey standard ... . . . . . . . . .

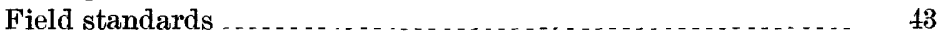

Description ...

Use $\ldots \ldots \ldots \ldots$

Iron $\ldots \ldots \ldots$

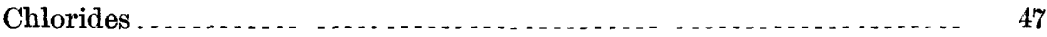

Laboratory determination

Field determination. ................... 50

Standard silver-nitrate tablets. . .

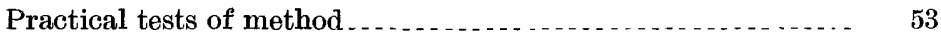

Estimation of chlorine ... $\ldots \ldots \ldots \ldots \ldots \ldots$

Hardness . . . . . . . . . . . . .

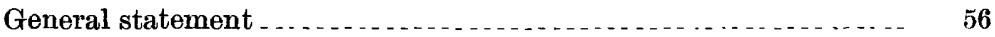

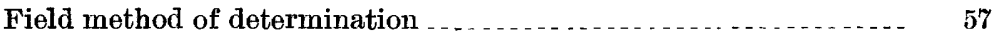

Use of sodium-oleate tablets. . . . .

Test of sodium-oleate tablets .......

Estimation of hardness . . . . 61

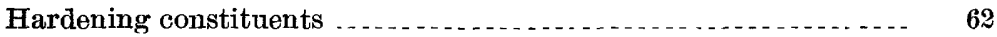

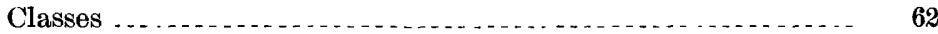

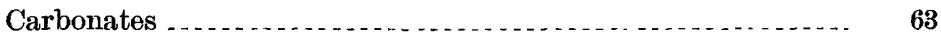

Tests of sodium acid-sulphate tablets.

Estimation of alkalinity .............. 66

Normal and acid carbonates.

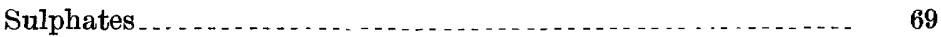

Determination by turbidimeter.

Precautions . . . . .

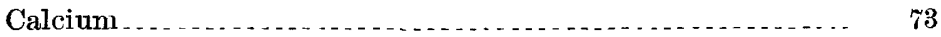

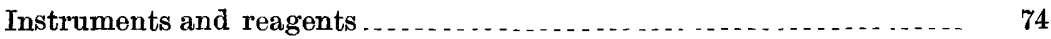

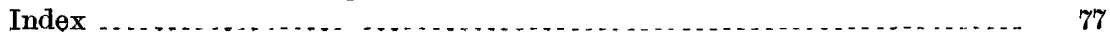





\section{L L U S T RAT I O NS.}

Page.

Plate I. Jackson's candle turbidimeter 26

II. Tubes and disks for determining color of water $\ldots \ldots \ldots$

III. United States Geological Survey tablet case _... . . . . . . . . . . . 50

IV. United States Geological Survey field case . . . . _ . . . . . . . . . 74

Fia. 1. Jackson's electric turbidimeter......................... 28

2. Logarithmic scale of turbidity $\ldots \ldots \ldots \ldots$

3. Turbidity curve $\ldots \ldots \ldots \ldots$ 



\title{
LETTER OF TRANSMITTAL.
}

\author{
Department of the INTERIOR, \\ United States Geological Survey, \\ Hydrographic Branch,
}

Washington, D. C., June 9, 1905.

SIR: I transmit herewith a manuscript entitled "Field Assay of Water," by Marshall O. Leighton, and request that it be published as one of the series of Water-Supply and Irrigation Papers.

In this manuscript are described and discussed the methods which have for some time been used with success in connection with the investigations into the quality of water in various parts of the United States carried on by the division of hydro-economics. As the methods have proved of value, it is believed that their publication in the form submitted will be of general interest.

Very respectfully,

F. H. NEwELL, Chief Engineer.

Hon. Charles D. Walcott,

Director United States Geological Survey. 



\section{FIELD ASSAY OF WATER}

By M. O. Leighton.

\section{INTRODUCTION.}

A chemist aims to secure exceeding refinement in analytical methods and results. He seldom considers whether or not a mothod is sufficiently exact for certain broad purposes. The fact that it is incomplete, approximate, or susceptible of refinement is to him sufficient reason for improving or rejecting it at the first opportunity.

The scrutiny to which chemical methods have been subjected in the endeavor to secure exact results has led in many cases to processes so complicated and expensive that in commercial work the advantages do not compensate for the increased cost and delay which the methods involve. The result has been that the chemical profession distinguishes between two classes of chemical methods which differ in degree of accuracy. The first includes the exact methods which afford results as nearly perfect as chemical procedure will permit. Such methods are used in all cases where minute differences in analysis would cause errors in interpretation or in subsequent chemical procedure. The second class consists of "commercial methods," so called because the results obtained by them, while departing from the actual truth, are sufficiently accurate to insure the profitable conduct of industrial chemical processes without appreciable error or waste. Methods of the first class are the product of chemistry, while those of the second are used in response to the demands of expediency - they are good enough for the purposes for which they are used.

In no branch of chemistry are approximate results more serviceable than in the analysis of water for hydro-economic surreys, or surveys made to determine the value of water and its applicability for use in domestic supply, boilers, industries, etc. Under the conditions which generally prevail it is necessary to resort to long, tedious, and expensive processes in order to secure a determination of the character and amount of foreign constituents in water. It is the practice in such cases to secure a sample of the water and transport 
it to a laboratory, where, after conventional delays it is passerl through the usual course of analysis.

There has in the past been surprisingly little discrimination used with reference to the selection of determinations for specific purposes, and as a general rule the same procedure has usually been followed without regard to the object of the particular investigation. If the purpose of the analysis is to determine the incrusting constituents, the course pursued has been to follow the entire analytical procedure. If, on the other hand, it is desired to determine the amo'int of organic pollution in a water and show its value for domestic use, the chemist forthwith begins the round of nitrogen determinations, and closes with a statement of the oxygen consumed and the number of bacteria per cubic centimeter. In only a few well-known laboratories has this rule been violated, and such is the conservatism in the chemical profession that it will probably be largely followed in future. Conservatism is the safeguard of science and one of the most commendable qualities of a chemist, but an excess is sometimes almost as bad as a deficiency.

\section{SANITARY ANALYSES.}

The requisites to be met by a water in almost every line of special development are broad and flexible. In the sanitary analysis certain results receive certain interpretations, which remain generally unchanged if the results are varied by $1,2,3$, or sometimes even 10 per cent. A strange feature in connection with sanitary analyses of water is that, in addition to insisting upon superrefinement, many chemists persist in making determinations that are admittedly to no purpose. It is a common thing to see an analyst's report of a water containing the results of determinations of albuminoid and free ammonia, nitrates, and nitrites, accompanied by a footnote stating that these results are unworthy of trust and mean ver:y little, except to verify conclusions made from inspection of the territory from which the water was taken. In case such conclusions do not agree with the analytical evidence, the latter is invariably discredited.

It is to be hoped that some day the great and growing swarm of water analysts will awaken to the fact that sanitary analyses, as generally applied and interpreted, are but a succession of unrelated absurdities. Water experts, who encounter real problems, who must use analytical data as'a basis for the design and construction of purification plants, and whose varied experience has tanght them that in the United States the waters are as diverse in character as the climates, have learned a few things not taught in text-books nor anticipated in the beautiful theory of the oxidation of organic matter.

The occasional isolated sanitary analysis of water is positively without value. There are throughout the country numerous State, munic- 
ipal, and private laboratories in which sanitary analyses are carried on. The water analyzed to-day may be from a well, to-morrow from a brook, and the next day from a pond. From the results of a single analysis wise and ponderous verdicts are sent broadcast, and the eager, waiting public is duly impressed. No one understands how singularly misleading a sanitary analysis of water can be until he has examined the results of such analyses of samples taken daily or hourly from the same source; then he sees that in general only a few single analyses in the group contain results which would admit of the interpretation that is finally placed upon the series.

If there is at hand a well-defined problem which involves the consideration of nitrogenous matter and the state in which it appaars in a water, certain daily nitrogen determinations are of undoubted value; not, however, by reason of the absolute amounts which are revealed in each determination, but by reason of the daily relations and variations which appear in the successive analyses, and upon which interpretations can be placed. This statement, it should be emphasized, refers almost entirely to water slightly or moderately polluted, and does not include sewage. The organic matter no"mally occurring in a natural water, or what may be more accurately described as a highly dilute sewage, is, after all, practically infinitesimal in amount. The difficulties attendant upon a determination of nitrogen in its various forms and the true interpretation of the results, grow less and less as the amount of organic matter is inc"eased. Yet, even with strong sewages some of the determinations, such as albuminoid ammonia and nitrites, are not usually productive of valuable information.

In an article entitled "The composition of sewage in relation to problems of disposal," ${ }^{a}$ Mr. George W. Fuller discusses in a characteristically clear manner an experiment which illustrates the apparent futility of the albuminoid-ammonia determination, as follows:

Illustrative of the varying relation of nitrogen in the form of albuminoid ammonia to the total organic nitrogen present in raw sewage, there are given below in a table the results of an experiment made in the Lawrence laboratory and published in the 1894 report of the Massachusetts State board of health, page 461. A bottle of fresh sewage was analyzed just after its collection and again at frequent intervals, allowing the natural decomposition processes to take place at room temperature. In this table it is seen that fresh sewage contains dissolved oxygen, coming, of course, from the water supply which forms the principal portion of the sewage. It also contains nitrogen in the form of nitrates, as well as other salts which are completely oxidized. Throrgh the agency of the bacteria and the oxygen dissolved in the water and yielded by the oxidized salts, the carbon of the organic matter is oxidized and the organic nitrogen uniting with the hydrogen forms free ammonia. 


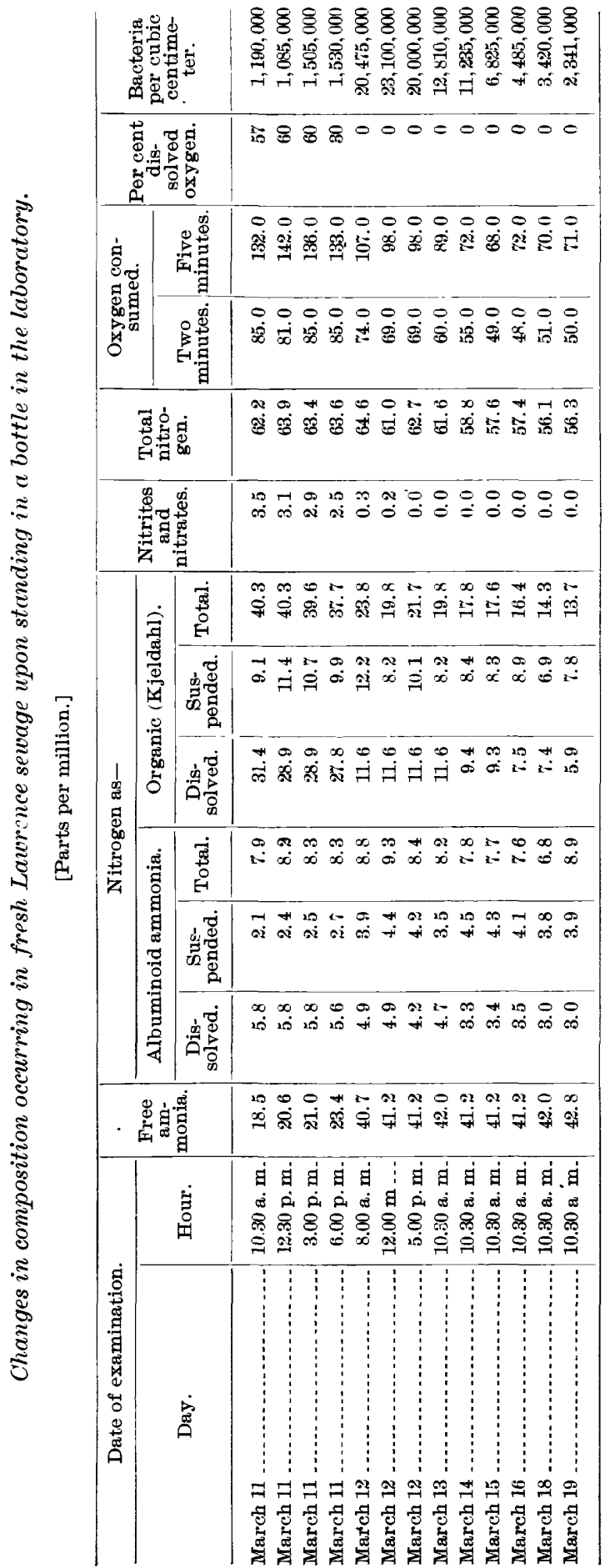


Thus it is seen from the results in the table, page [12], that the dissol "ed oxygen and the nitrates gradually disappear, the bacteria for a time increase, the oxygen consumed (carbonaceous matter) decreases, the nitrogen as fre? ammonia increases, and the organic nitrogen (Kjeldahl) decreases. The nitrogen as albuminoid ammonia, however, remains approximately constant, notwithstanding that more than 20 parts of organic nitrogen are changed to free ammonia, and some 5 or 6 parts of free nitrogen escape into the atmosphere.

The nitrite determination, which has been regarded by many as one of the most valuable pollution indicators, fluctuates in a stream or reservoir according to the amount of available oxygen rathor than the amount of organic matter undergoing oxidation. It will rise and fall in amount when there is a positive certainty that it can not be due to increase or decrease of organic pollution. Nevertheless, many an interpretation has been made largely on the evidence presented by this determination:

By far the greater number of sanitary water analyses reported include the determination of oxygen consumed, a test which is dependent upon so many features that as a whole the great mass of determinations which have been made are valueless for purposes of comparison. The following table, compiled by Mr. George W. Fuller, shows clearly the relative results of the determination: made according to different methods. In short, the only practical value of the "oxygen-consumed" determination is in its application to highly polluted waters of the same general character and origin, ard then only for purposes of comparison between the successive determinations made by absolutely the same method. In other word. it is essentially a sewage determination.

Approximate comparison of average amounts of oxygen consumed by sewage and sewage effuents as shown by different methods.

\begin{tabular}{|c|c|c|c|}
\hline Method. & $\begin{array}{l}\text { Temperature } \\
\text { of solution. }\end{array}$ & Period of contact. & $\begin{array}{l}\text { Relative } \\
\text { results. }\end{array}$ \\
\hline $\begin{array}{l}\text { Kübel, as practiced at Boston and gener- } \\
\text { ally in America. }\end{array}$ & Boiling & 5 minutes ..... & 1.00 \\
\hline Kübel, as practiced at Lawrence, Mass & $\ldots$....do & 2 minutes .... & .65 \\
\hline Kübel, as practiced in Germany ..... & $\ldots . . . d o \quad \ldots$. & 10 minutes $\ldots .$. & 1.25 \\
\hline English official tests & $\left\{\begin{array}{l}0 . \\
\ldots \text { do }\end{array}\right.$ & 4 hours & $\begin{array}{l}.20 \\
.35 \\
.60\end{array}$ \\
\hline "Absolute" oxygen consumed & Boiling ... & $\ldots$ do $\ldots . . . . .$. & 4.00 \\
\hline
\end{tabular}

\section{INORGANIC ANALYSES.}

In the determination of inorganic constituents in a water it would make no difference, in the decision to accept or reject that water for boiler use, for irrigation, or for manufacturing, if the harmf $\mathrm{l}$ constituents were contained, for example, in the proportion of 40,44 , or 48 grains per gallon. The lines dividing good and bad water for 
boiler purposes are very broad. If a water contains a certain amount of incrusting constituents and a method used is inaccurate to a limit of 5 , or even 10, per cent, it would not lead to the acceptance of a bad water or the rejection of a good one. The "good" and "bad" provinces are approached too gradually to admit of such consequences.

Another error arises from the conventional methods of expression of results. If the analyst finds that a water contains certain amounts of calcium, magnesium, sodium, and potassium, and certain equivalents of the carbonate, sulphate, and chloride radicals, he unites these substances according to methods which are apparently not uniform and entitled to little scientific justification. It is a well-known fact that if several chemists, each independent of every $o^{\text {ther, analyze a }}$ certain water, there will almost invariably be wide differences in the expression of results.

Dr. F. W. Clarke, chief chemist of the United States Geólogical Survey, in a recent communication has given an excellent illustration of the various hypothetical combinations which may be made of the results of a single analysis of water. The statements are set forth in the following table. Each series of combinations is based upon a generally accepted hypothesis, and each represents $s$ water that is tetally different from the others.

Analysis of water from artesian well at Macomb, Ill.a

[Grams per liter.]

\begin{tabular}{|c|c|c|c|c|c|c|}
\hline \multicolumn{2}{|c|}{ Statement in ionic form. } & \multicolumn{5}{|c|}{ Statement according to hypothetical combinations. } \\
\hline $\mathrm{SiO}_{2}$ & 0.0105 & KCl & & 0.0452 & 0.0181 & 0.0211 \\
\hline $\mathrm{Al}_{2} \mathrm{O}_{3}$ & .0013 & $\mathrm{NaCl}_{\ldots} \ldots$ & 0.8968 & .8384 & .7164 & .8172 \\
\hline $\mathrm{Fe}_{2} \mathrm{O}_{3}$ & .0023 & $\mathrm{CaCl}_{2}-$ & & (n...... & $.08 \% 7$ & .0292 \\
\hline $\mathrm{SO}_{4} \ldots$ & .9991 & $\mathrm{MgCl}_{2-}$ & 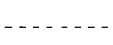 & .0154 & .0571 & .0242 \\
\hline $\mathrm{CO}_{3} \ldots$ & .3953 & $\mathrm{~K}_{2} \mathrm{SO}_{4-}$ & .0528 & ....... & .0211 & .0246 \\
\hline Cl _. - & .5418 & $\mathrm{Na}_{2} \mathrm{SO}_{4-.}$ & .4649 & 1.4781 & 1.2495 & 1.0642 \\
\hline $\mathrm{Na}$ & .8086 & $\mathrm{CaSO}_{4-\ldots}$ & .5450 & $\ldots \ldots$ & .1218 & .2223 \\
\hline $\mathbf{K}_{\ldots}$ & .0237 & $\mathrm{MgSO}_{4} \ldots$ & .3360 & & .0711 & .1357 \\
\hline $\mathrm{Ca} \ldots$ & .1581 & $\mathrm{~K}_{2} \mathrm{CO}_{3} \ldots$ & ...... & $\cdots$ & .0084 & .0028 \\
\hline \multirow[t]{7}{*}{ Mg ... } & .0672 & $\mathrm{Na}_{2} \mathrm{CO}_{3} \ldots$ & .6983 & $\ldots$ & .2793 & .3259 \\
\hline & & $\mathrm{CaCO}_{3}$ & ...... & .3952 & .2278 & $.20 \% 6$ \\
\hline & & $\mathrm{MgCO}_{3}$ & $\ldots \ldots$ & .2215 & .1355 & .1190 \\
\hline & & $\mathrm{Al}_{2} \mathrm{O}_{3} b$ & .0013 & .0013 & .0013 & .0013 \\
\hline & & $\mathrm{Fe}_{2} \mathrm{O}_{3}{ }^{b}$ & .0020 & .0020 & .0020 & .0020 \\
\hline & & $\mathrm{SiO}_{2} b \ldots \ldots$ & .0105 & .0105 & .0105 & .0105 \\
\hline & & & 3.0076 & 3.0076 & 3.0076 & 3.0076 \\
\hline
\end{tabular}

$a$ By George Steiger, laboratory of United States Geological \& rurvey.

$b \mathrm{Al}_{2} \mathrm{O}_{3}, \mathrm{Fe}_{2} \mathrm{O}_{3}, \mathrm{SiO}_{2}$, conventionally regarded as colloidal. 
The inorganic constituents of a water should invariably be expressed as positive and negative ions, and if so expressed th a result determined according to approximate methods is as valuablo as the expression of precisely determined constituents united according to the individual ideas of the analyst.

\section{GENERAL OBSERVATIONS.}

A practical disadvantage in chemical water surveys arising from the insistence on refined methods of analysis and lack of discrimination in the choice of specific determinations is the delay which arises in securing valuable information with reference to wide areas. Months and even years have been spent upon water surveys covering only a comparatively small portion of the country. Two examples are here cited.

The most important chemical survey in the United States has been carried on since 1888 by the Commonwealth of Massachusetts. This survey work may safely be taken as the standard in this or any other country. During this period of sixteen years the appropriations for the work have been on an average about $\$ 30,000$ a year, making a total cost of not far from $\$ \$ 80,000$. A large part of this sum has been used to pay expenses of experimentation and can not be charged to water survey. The work was confined to Massachusetts.

In the year 1898 the Ohio State board of health commenced an examination of the principal streams of the State, making monthly analyses of samples of water taken from numerous points along the various streams. This work was continued five years before the State was covered, and there resulted merely a large number of periodical analyses in sets of twelve, showing the character of the stream water and its variation according to local conditions.

These two cases are typical. No one would claim that all the results could have been reached by the use of field methods. Undoubtedly a large part of them could have been obtained far more cheaply and quickly, and there would have been no loss to th 9 cause of pure water, nor to science generally, had some of the determinations been omitted.

Among water analysts there seems to be a general tendency to attack every water problem as though the object were to prove its fitness or unfitness for drinking purposes. In many investigations it is well known at the outset that the water can not be used for domestic purposes and the problem is of quite another character. The conventional grind of nitrogen determinations has been made to do service in almost every conceivable water problem. It has been used frequently in investigating pollution problems in which organic matter had absolutely no part. A study of the results obtained in many 
laboratories will show that in the routine work a nurber of determinations could be omitted without detriment. These facts are mentioned in order to emphasize the point that if care and discrimination were used in the selection of tests the work necessary in carrying on chemical surveys might be decreased and the money available for such work might be distributed over a wider field; results of more immediate use might be secured and the completion of a chemical survey would not be postponed for the benefit of future generations. "Commercial methods" serve useful pur'oses in manufacturing; the success of enormous industrial plants is dependent upon them, and in water surveys they would at least be businesslike.

It was these considerations, in connection with the knowledge of the vast areas covered by the United States, which led the United States Geological Survey, through its hydro-economic division, to investigate the practicability of employing field methods for the determination of important characteristics of water. It was realized that if there could be provided a few simple tests, the apparatus for which could be taken into the field and used on the spot, large areas might be covered in a short time, and if it were necessary for any reason to make periodical determinations the cost of tl a work would still be small and the total would not run up into the large sums which have been spent in such investigations. In genoral, the testimony of a large number of approximate results is for more representative of actual conditions than that of one or two refined analyses.

The idea of testing waters in the field is by no means new. Very successful field tests have been carried on by numero'us authorities. Probably one of the most successful systems now in use is that of the Bureau of Soils, Department of Agriculture. Another excellent field outfit for sanitary analysis has been devised and used with satisfaction by Mrs. Ellen H. Richards. Several others are noteworthy. They all involve the use of considerable apparatus and the carrying of standard solutions. Specially equipped wagons are necessary in some cases. In others the variety of determinations is limited or the equipment can not be used in an extensive circuit without renewal of reagents. The difficulty of carrying solutions and complex apparatus into the field is obvious. The ideal equipment is one which can be carried on journeys afoot or on horseback without much fatigue. 'The sources of useful or desirable water supply are not distributed with reference to the railroad or wagon routes and the field man must often climb mountains or trace obscure trails to accomplish his purpose. The outfit should contain a sufficient supply of reagents to serve for a large number of determinations without renewal. The processes should be rapid and the results fairly accurate and comprehensive. Finally, the equipment should be provided with material for so various a series of deterninations that with proper discrim- 
ination the essential characteristics of a water may be shown, whether the purposes be domestic or industrial water supply, irrigation, or any other special line of utilization. Volumetric methods rexuiring the use of burettes are objectionable; gravimetric methods are impossible. Therefore, in the Survey's study of field methods the whole matter developed into a question of choosing the most useful determinations and so modifying the volumetric methods that their use would be practicable, while at the same time they would give a degree of accuracy sufficiently close for all practical purposes.

To the methods hereinafter proposed the term "assay" readily lends itself. There is no attempt at water analysis. The plan contemplates the determination of ingredients which give to water certain well-known characteristics. The methods and the suggestions with reference to their application are only tentative and will be modified as experience may dictate. As they stand they are the revult of extended experimentation, and the tests to which they have been put show that they are practicable. They have been found to b? more nearly accurate than was at first anticipated, though this fact, it is believed, has not greatly increased their usefulness for the purposes in view. By their use, combined with a fair amount of common sense, the essential characteristies of waters can be ascertained at small expense. In almost every situation in which such determinations are significant they will afford sufficiently satisfactor ${ }^{\top}$ data. In the case of finely balanced considerations of a purely pl ysical, chemical, or geologic nature, however, they are practically useless. They are intended for practical purposes and have no place in pure science.

\section{FIELD DETERMINATIONS.}

The following determinations are described on subsequent pages:

1. Turbidity.

2. Color.

3. Iron.

4. Chlorine or total chlorides.

5. Total hardness.

6. Alkalinity.

7. Normal carbonates.

8. Bicarbonates.

9. Total sulphates.

10. Calcium.

It should be stated at the outset that the successful operation of these methods depends, as in all chemical procedure, upon the manner in which they are applied. A failure to insist upon strict compliance with the rules laid down may result in total failure.

IRR $151-05-2$ 


\section{SUSPENDED MATTER.}

The turbidity of water is that property which is imparted to it by substance carried in suspension. In many parts of the United States waters are often extremely muddy, and when this concition is maintained during long periods it becomes one of the most, serious difficulties with which the water-supply engineer has to deal. Turbid water is objectionable for domestic use. In industrial operations, especially in those in which water enters into manufacturing processes, turbidity is a factor which, if not removed, may exert a harmful influence upon the manufactured products. It is \& lso important in connection with irrigation works. One of the serious troubles in Western reservoirs is loss of storage capacity due to silt deposits. In the construction of irrigation canals the amount of turbidity usually carried by the water often determines the grade of the canal. Such canals must have grade sufficient to cause the flowing water to carry along suspended matter and not allow it to settle. If th is is not taken into consideration, the maintenance of the irrigation system becomes extremely expensive, and cases have occurred where tle canals have been practically filled by the deposits of suspended matter.

The suspended substances causing turbidity are of various characters. They are found often in a flocculent condition, settling readily when the water which carries them becomes quiescent. On the other hand, the turbid matter is often made up of minute particles of clay, so fine that they pass through certain filtering media. In some cases the problem of removing turbidity from the water is so difficult that the process which may be successful is so radical that it will remove also dissolved organic material and ever a large number of the bacteria.

\section{METHODS OF DETERMINATION.}

There are several methods of estimating the proportion of suspended matter in a water, all but one of which have their particular fields of usefulness. The first is merely a statement of the observer's opinion of the degree of turbidity, such as "very slight," "slight," "distinct," or " decided." Although this method of estimation has no real value, it is used by many water chemists.

The second method is also based upon the appearance of the water, but differs from the first in that a definite and fairly vell-fixed basis of comparison is provided. A water containing no susnended matter is practically transparent, but matter in suspension intercepts the rays of transmitted light. An observer can see objocts distinctly through a body of clear water, but as the water becomes more and more muddy the objects can be seen less and less dịstinctly until 
they are quite lost to view. Now, it has been found by expariment that there is a fairly definite relation between the proportion of light rays intercepted and the amount of matter in suspension. This relation varies somewhat with the character of the suspended matter and with the size of the particles, but for the purpose to which this method of measurement is applicable the variations do not often seriously affect the interpretations placed upon the results. The details of the method will be explained on later pages under the caption "Turbidity." For the present it will be sufficient to state that it has found its greatest usefulness in connection with the adaptation and operation of water-filtration plants and sewagedisposal works.

The third method of measuring the amount of suspended matter in water consists in separating it from a weighed portion of the fluid by filtration, weighing the filtered water, and stating the difference between the two weights as suspended matter. The form of statement commonly used is parts of suspended matter per million of water, milligrams per liter, or some other comprehensive proportion. This is undoubtedly the best method of determination, as it is relatively accurate and can be used in the study of all water problems. Its practical disadvantage is that the determination requires a large amount of time and can not be economically performed in serial investigations without considerable equipment and tedious labor. It is also true that the processes for which a knowledge of suspended matter is necessary will generally in practical work be as well served by an approximate determination as by a precise one; therefore the cruder methods, based upon photometry, are more often used.

There is, however, no necessarily constant relation between the weight of suspended matter in a given volume of water and the turbidity produced. A certain weight of suspended substince of one kind does not usually produce the same degree of turbidity as a similar weight of another substance. In other words, the turbidity determination takes no account of the character, weight, or volume of the suspended matter. This has been clearly demonstrated by Mr. Robert Spurr Weston in the report on Water-Purification Investigation and on Plans Proposed for Sewerage and Waterworks Systems made to the sewerage and water board of New Orieans, La., pages 27 and 28 . To overcome the errors above cited, Mr. Weston has proposed the use of a "turbidity coefficient," as follows:

All optical methods for the determination of turbidity are naturally compared with the gravimetric determination of the suspended matter which produces the turbidity. Equal weights of suspended matter do not necessarily produce the same turbidity. For example, waters which contain suspended silt or sand exhibit less turbidity per unit of suspended matter by weight than do waters containing finely divided clay. Therefore the ratio between silica turbidity, 
determined optically, and suspended matter, determined gravimetrically, is most important, as it is an index of the character of the suspended matter producing the turbidity. To express this relation most converiently, the term "turbidity coefficient" has been adopted.

$$
\text { Turbidity coefficient equals } \frac{\text { Suspended matter. }}{\text { Silica turbidity. }}
$$

Naturally this coefficient varies with different waters, generally increasing with the size of the particles composing the suspended matter. Thus the samples of unsettled river water have the highest turbidity coefficient, while samples from the effluents of the three-day subsiding basins have the lowest, as the following table will show:

Table of average turbidity coefficients.

Turbidity coefficient.

Mississippi River water-_._.

Mississippi River water, after 6 hours' subsidence

Mississippi River water, after 12 hours' subsidence

Mississippi River water, after 18 hours' subsidence $\ldots \ldots \ldots \ldots \ldots \ldots \ldots \ldots$

Mississippi River water, after 24 hours' subsidence

Mississippi River water, after 48 hours' subsidence

Mississippi River water, after 24 hours' subsidence and coagulation_-_-_-_ . 60

This table is very easy to understand, since the coarser particles of low turbidity-producing power and somewhat higher specific gravity gradually separate out according to their hydraulic values, the finer particles of high turbidity-producing power and somewhat lower specific gravity remaining longest in suspension.

The idea of Mr. Weston above set forth is an admirable one and should be utilized in connection with all water investigations.

The fourth method of determining suspended matter consists in measuring the cubical contents thereof after sedimentation. This method takes no account of the weight of the substance nor of the turbidity produced by it, and its particular value is cenfined to those highly turbid waters which it is proposed to conserve in storage reservoirs or to conduct in canals. In the preparation of reservoirs for irrigation and domestic uses in the arid and semiarid regions, one of the most troublesome features is the loss of storage capacity in the reservoir by reason of its filling up with matter deposited from sus. pension, and indeed it is necessary in the construction of these reservoirs to provide means whereby the silt can be removed at proper intervals. The problem is, therefore, one of cubical contents and the observations are usually made by filling a 100 c. c. graduate with the turbid water, allowing the suspended matter to settla, and reading the depth of the sediment and expressing it in percentoge terms.

The results of such observations do not bear any mor 3 constant relation to the turbidity produced by the suspended matter than do the determinations of actual weight. An interesting series of observations upon this point has recently been compiled by the Geological. 
Survey, the water being taken from Gila River at San Carlos, Ariz. This river is probably the muddiest in the United States, and the observations represent extreme conditions. Turbidity measurements consume so small an amount of time in comparison with that nocessary in the observation of per cent volume of total solids that an endeavor was made to determine whether or not turbidity measurements possess any constant relation to amount of matter. If such were found to be the case the work necessary in preparing plans for storage reservoirs would be considerably shortened.

Parallel determinations were therefore made of turbidity and per cent volume of sediment upon daily samples taken from Gila River from July 21 to October 24,1904 , the results of which are set forth in the following table. It will be noted in this table that the conversion factor, which should be constant if the hypothesis were correct, varies so widely as to indicate unmistakably the entire absence of any constant relation between the two sets of observations:

Parallel observations of per cent volume of sediment and of turbidity, in terms of parts per million, of silica in water from Gila River at San Carlos: Ariz.

\begin{tabular}{|c|c|c|c|c|c|c|c|}
\hline Date. & $\begin{array}{l}\text { Per cent } \\
\text { sediment } \\
\text { volume. }\end{array}$ & $\begin{array}{c}\text { Turbidity } \\
\text { (silica parts } \\
\text { per million). }\end{array}$ & $\begin{array}{c}\text { Conversion } \\
\text { factor. }\end{array}$ & Date. & $\begin{array}{l}\text { Per cent } \\
\text { sediment } \\
\text { volume. }\end{array}$ & $\begin{array}{c}\text { Turbidity } \\
\text { (silica parts } \\
\text { per million). }\end{array}$ & $\begin{array}{l}\text { Conversion } \\
\text { factor. }\end{array}$ \\
\hline July 21 . & 12 & 27,300 & 2,280 & Aug. 12. & 15 & 63,936 & 4,260 \\
\hline 22 & 16.5 & 37.800 & 2,290 & 13 & 10 & 57,600 & 5,760 \\
\hline $23 \ldots$ & 19 & 43,200 & 2,280 & $14 \ldots$ & 11 & 33,550 & 3,050 \\
\hline $24 \ldots$ & 18.5 & 43,200 & 2,340 & $15 \ldots$ & 17 & 48,000 & 2,820 \\
\hline 25. & 21 & 44,784 & 2,140 & 16. & 18.5 & 54,000 & 2,920 \\
\hline 26 . & 18 & 41,568 & 2,310 & $17 \ldots$ & 15 & 42,000 & 2,800 \\
\hline 27. & 16 & 40,572 & 2,540 & 18 & 13 & 39,000 & $3, \dot{0} 00$ \\
\hline 28 & 9 & 40,800 & 4,530 & 19 & 9 & 33,000 & 3,670 \\
\hline $29 \ldots$ & 21 & 53,000 & 2,520 & 20 & 12 & 39,000 & 3,250 \\
\hline $30 \ldots$ & 19 & 64,000 & 3,370 & 21. & 15.5 & 36,000 & 2,320 \\
\hline 31 & 12 & 64,000 & 5,330 & 22 & 13 & 36,000 & 2,770 \\
\hline Aug. 1 - & 13 & 53,312 & 4,110 & $23 \ldots$ & 10 & 27,000 & 2,700 \\
\hline 2 & 22 & 78,536 & 3,340 & $24 \ldots$ & 13 & 39,000 & 3,000 \\
\hline 3. & 20 & 67,200 & 3,350 & $25 \ldots$ & 8 & 30,000 & 3,750 \\
\hline 4. & 19 & 70,368 & 3,680 & $26 \ldots$ & 9 & 30,000 & 3,340 \\
\hline $5:-$ & 15 & 63,936 & 4,260 & $27 \ldots$ & 8 & $2 \pi, 000$ & 3,380 \\
\hline 6. & 15 & 62,400 & 4,160 & 28 & 8 & 24,000 & 3,000 \\
\hline $7 \ldots$ & 14 & 62,400 & 4,460 & 29 & 8 & 27,000 & 3,380 \\
\hline 8 & 15 & 67,200 & 4,480 & $30 \ldots$ & 8 & 27,000 & 3,380 \\
\hline 9. & 14 & 63,936 & 4,560 & 31. & 8 & 21,000 & 2,630 \\
\hline 10. & 14 & 60,768 & 4,340 & Sept. 1.- & 8.5 & 28,500 & 3,360 \\
\hline $11 \ldots$ & 13 & 62,400 & 4,800 & $2 \ldots$ & 8.5 & 30,000 & 3,520 \\
\hline
\end{tabular}


Parallel observations of per cent volume of sediment and of turbidity, in terms of parts per million, of silica in water from Gila River, etc.-Continued.

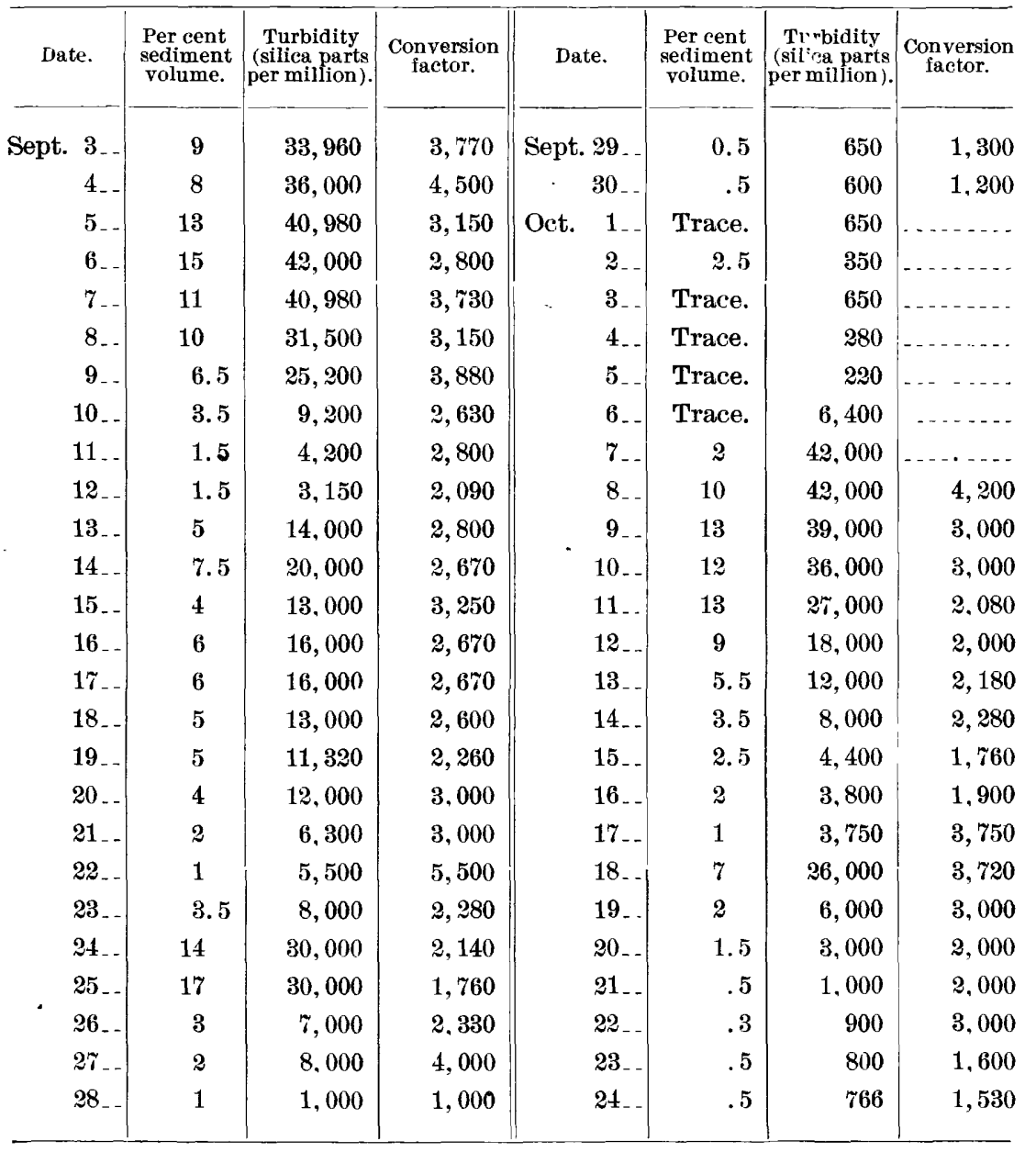

TURBIDITY.

As all the usual methods for the determination of turbidity are fairly faniliar, having been repeatedly described in numerous scientific journals, no further statements are necessary here. It is customary at the present time to adopt as a basis for the scale of each an absolute turbidity produced by a definite amount of finely divided silica in a certain volume of water. The scale has been described by its originators, Messrs. George C. Whipple and Daniel D. Jackson, in Technology Quarterly, Vol. XII, No. 4, December, 1899, pages 283-287. 


\section{UNITED STATES GEOLOGICAL SURVEY TURBIDITY ROD.}

DESCRIPTION.

This rod, devised by Messrs. Allen Hazen and George C. Thipple, is a modification of the original Hazen rod, and is described in the following extract from circular No. 9 of the division of hydrography, United States Geological Survey:

Proposed turbidity standard.-The standard of turbidity shall be a water which contains 100 parts of silica per million in such a state of fineness that a bright platinum wire 1 millimeter in diameter can just be seen when the center of the wire is $\mathbf{1 0 0}$ millimeters below the surface of the water and the eye of the observer is 1.2 meters above the wire, the observation being made in the middle of the day, in the open air, but not in sunlight, and in a vessel so large that the sides do not shut out the light so as to influence the results. The tr rbidity of such water shall be 100 .

The turbidity of waters more turbid than the standard shall be computed as follows: The ratio of the turbidity of the water to 100 shall be as the extended volume is to the original rolume when the water is diluted with a clear water until the mixture is of standard turbidity.

The turbidities of waters lower than the standard should be computed as follows: The ratio of the turbidity of the water to 100 shall be as the ratio of the original volume of water of stanclard turhidity is to the extended vol tme when such water is diluted with clear water until its turbidity is equal to that of the water under exanination.

This standard can be used in both field and laboratory. In the field the wire method will be employed as at present, except for a new graduation, while in the laboratory the methods of dilution and comparison now in use for the silica standard will be employed.

Method of application to the platinum-urire process.-A rod with a platinum wire inserted in it at a fixed point and projecting from it a right angle will be used, as at present. The graduation shall be as follows: The graduation mark of 100 shall be placed on the head of the rod at a distance of 100 millimeters from the center of the wire. Other graduations will be made, based on the best obtainable data, in such a way that when a water is diluted the readings will decrease in the same proportion as the percentage of the original water in the mixture. Such a rod, having the graduation shown in the table below, shall be known as the United States Geological Survey turbidity rod of 1902. When this rod is immersed in water, the visibility of the projecting platinum wire at the depth from the surface shown in the second column will determine the degree of turbidity, as indicated in the first column. 
Graduation of turbidity rod of 1902.

\begin{tabular}{|c|c|c|c|c|c|}
\hline Turbidity. & $\begin{array}{c}\text { Depth of } \\
\text { wire. }\end{array}$ & $\begin{array}{l}\text { Corre- } \\
\text { sponding } \\
\text { value on } \\
\text { reciprocal } \\
\text { scale. }\end{array}$ & Turbidity. & $\begin{array}{c}\text { Depth of } \\
\text { wire. }\end{array}$ & $\begin{array}{l}\text { Corre- } \\
\text { sronding } \\
\text { ralue on } \\
\text { reciprocal } \\
\text { scale. }\end{array}$ \\
\hline & $m m$. & & & $m m$. & \\
\hline 7 & 1,095 & 0.023 & 70 & 138 & 0.184 \\
\hline 8 & 971 & .026 & 75 & 130 & .196 \\
\hline 9 & 873 & .029 & 80 & 122 & .208 \\
\hline 10 & 794 & .032 & 85 & 116 & .219 \\
\hline 11 & 729 & .035 & 90 & 110 & .230 \\
\hline 12 & 674 & .038 & 95 & 105 & .242 \\
\hline 13 & 627 & .041 & 100 & 100 & .254 \\
\hline 14 & 587 & .043 & 110 & -93 & .273 \\
\hline 15 & 551 & .046 & 120 & 86 & .295 \\
\hline 16 & 520 & .049 & 130 & 81 & .314 \\
\hline 17 & 493 & .052 & 140 & 76 & .334 \\
\hline 18 & 468 & .054 & 150 & 72 & .35 \\
\hline 19 & 446 & .057 & 160. & 68.7 & .37 \\
\hline 20 & 426 & .060 & 180 & 62.4 & .41 \\
\hline 22 & 391 & .065 & 200 & 57.4 & .44 \\
\hline 24 & 361 & .070 & 250 & 49.1 & .52 \\
\hline 26 & 336 & .076 & 300 & 43.2 & .59 \\
\hline 28 & 314 & .081 & 350 & 38.8 & .65 \\
\hline 30 & 296 & .086 & 400 & 35.4 & .72 \\
\hline 35 & 257 & .099 & 500 & 30.9 & .82 \\
\hline 40 & 228 & .111 & 600 & 27.7 & .92 \\
\hline 45 & 205 & .124 & 800 & 23.4 & 1.09 \\
\hline 50 & 187 & .136 & 1,000 & 20.9 & 1.21 \\
\hline 55 & 171 & .148 & 1,500 & 17.1 & 1.49 \\
\hline 60 & 158 & .160 & 2,000 & 14.8 & 1.72 \\
\hline 65 & .147 & .172 & 3,000 & 12.1 & 2.10 \\
\hline
\end{tabular}

This table is compiled from observations made at Cincinnati. St. Louis, New Orleans, Pittsburg, Brooklyn, Philadelphia, and Boston, for records of which we are indebted to several observers. The values of the turbidities by the reciprocal scale are included in the table for conrenience, but they do not form a part of the standard.

This graduation is subject to revision whenever additional data shall make it necessary and revised rods shall be designated by the same name, but with the year of revision substituted for 1902 . The revisions shall have as their basis the 100 mark, 100 millimeters from the wire.

Near the end of the rod, at a distance of 1.2 meters from the platinum wire, a wire ring shall be placed directly above the wire, through which the observer will look, the object of the ring being to control the distance from the wire to the eye. 
When the turbidity is greater than 500 the water should be diluted before the observation is made. When the turbidity is below 7 this method can not be used, and comparison should be made with the silica standard proper'y diluted in bottles or tubes, as described by Whipple and Jackson in Technoligy Quarterly, Vol. XII, No. 4, December, 1899.

The number obtained by dividing the weight of suspended matter in parts per million by the turbidity as obtained above shall be called the coefficient of fineness. If greater than unity it indicates that the matter in suspens ion in the water is coarser than the standard; if less than unity, that it is fine: than the standard.

This standard is proposed with the idea of combining the best features of the platinum-wire and silica methods of measuring turbidities as commonly used, and of avoiding, as far as possible, the objections to each.

OBJECTIONS TO ROD METHOD.

The method of turbidity determination above outlined answers all purposes demanded in ordinary use. In field determinations it has many objections which are not easily overcome. It was readily observed in practice that the method is largely a test of the individual and that the point at which the wire disappears from view varies according to the eyesight of the observer. Under ordinary conditions this variation is not sufficient to influence the interpretations placed upon the results, but there are some conditions under which the variation would be large enough to cause considerable error.

Again, the method was found to be inaccurate and unsafe ị determining turbidity above 100 . It is also difficult to select the conditions prescribed in the directions above set forth. A person in the field is governed absolutely by the conditions which he meets, and it is exceptional when he is able to be at a desired point at a giren time. Therefore the observation, which must be made " in the midcle of the day, in the open air, but not in sunlight, and in a vessel so large that the sides do not shut out the light," is in most cases an undertaking of extreme difficulty. Another observation is more importent; it is necessary for the field man to take observations in the running stream. Obviously it would be impracticable to carry about a container large enough to meet these prescribed conditions, and in the majority of cases a turbidity reading must be taken at long distances from points at which such containers can be borrowed. It is well known that in many cases the suspended matter in running streams occurs' in clouds. In a certain section of the stream the turbidity at one moment may be high and at the next moment much reduced, or vice versa. Often the observer, after fixing the point at which the platinum wire disappears, finds that before he is able to read the scale the wire is either plainly in sight or has become submerged below the point of correct turbidity reading. 
All these objections make the use of the turbidity rod undesirable in general field work. While its value at selected stations is acknowledged, it has been found to be impracticable under less favorable circumstances; consequently a new method was sought.

\section{JACKSON'S TURBIDIMETER.}

DESCRIPTION.

The needs of the Survey were found to be met in a satisfactory manner by the use of a turbidimeter devised by Mr. Daniel D. Jackson, chemist in charge of the Mount Prospect laboratory, department - of water supply, gas, and electricity, city of New York. The following is a report by Mr. Jackson with reference to this instrument:

The suspended matter or turbidity in natural waters is the most important physical characteristic in many sections of the country. In such sections the selection of new water supplies, as well as the improvement of existing supplies, rests, to a very great extent, upon a consideration of this particular feature. These milky or muddy waters are often quite variable in the amount and nature of their suspended matter, and, in case they are to be purified. require considerable study to deternine the proper treatment.

When the maximum and the average turbidity in a water are known, questions may be solved relating to the nature, size, and construction of settling basins. filter plants, and clear-water reservoirs, and, finally, in determining the effi. ciency of the removal of suspended matter in such filter plants we must know the turbidity of the water before and after filtration.

The hydrographic branch of the United States Geological Survey is particularly interested in developing accurate and rapid methods for the determination of turbidity, both for data relating to water supplies as well as relating to the erosion and the carrying power of suspended matter by rivers and streams. It is necessary that the field methods should be comparable with those of the laboratory, that the work should be rapidly accomolished, and that the results should express, as nearly as possible, the actual weight of the suspended matter present.

If we determine the total solids in a water before and after filtration through a Berkfeld filter, the difference in the results obtained will gire the weight of the suspended matter present, but this metlod is tedious in the laboratory and impossible in the field. It is evident that some photometric standard of comparison must be used, and extensive studies have shown that whatever the instrument employed for this purpose it should be graduated by a standard turbid water. The standard now employed is known as the "silica standard," and is made from diatomaceous earth. $a$

This standard is preferable to all. others that have been uved in that it is absolutely insoluble, has a very uniform size of particle, and, unlike clas, does not cake together on standing. The diatomaceous earth (inf rsorial earth) is found in natural deposits in many parts of the country. To prepare the standard this material is first washed and ignited to free it from organic matter. It is then ground to an impalpable powder in an agate mortar, put through a 200 mesh sieve to break up the lumps produced in grinding, treated with dilute hydrochloric acid, and the finest portion decanted. This fine portion is then dried at $100^{\circ} \mathrm{C}$., cooled in a desiccator, and kept in a tightly stcppered bottle.

a Whipple, G. C., and Jackson. D. D., Silica standards for the determination of the túrbidity in water: Techn. Quart., vol. 12, No. 4, Dec., 1899. 


$$
\text { id }
$$


One gram of this material is weighed out and put into 1 liter of distilled water. The mixture represents a standard of 1,000 parts per million of silica turbidity, and dilutions may be made from this for comparison with natural waters. Readings made with this standard compare very well with the actual weight of the suspended matter in water, but it has been found that the standard as prepared varies slightly when made by different analysts. The author now proposes to make the standard absolute by making readings on the candle turbidimeter and so adjusting the mixture that the standard of 1,000 parts per million will always read 2.3 centimeters on the instrument.

THE CANDLE TURBIDIMETER.

The original form of this instrument was first described by the writer in the Journal of the American Chemical Society, November, 1901, but since th't time it has been considerably improved upon. The accompanying illustration gives a good idea of the present form of the instrument and its use. [See PI. I.] The apparatus consists of a glass tube, closed at the bottom and graduated in centimeters and millimeters depth. This is surrounded by a brass holder, open at the bottom and supported by a stand, in the center of which is a standard English candle, so adjusted by means of a spring below that its top rim is always just 3 inches below the bottom of the glass tube.

The water to be determined for turbidity is poured into the glass tube until the image of the lighted candle below just disappears. $a$ The depth of the water in the tube is then read (using the bottom of the meniscus), and this depth is corpared with a table which gives the turbidity of the water in parts per million of silica. The tube itself may be graduated in turbidity as well as in millimeters depth, thus dispensing with the use of the table. Between 5,000 and 100 parts per million of silica a tube $\mathbf{2 5}$ centimeters in length is necessary, or a comnarison with silica standards in tubes or bottles may be substituted. The candle instrument is very convenient in the laboratory, and as its source of light is the standard candle it is ready for use at all times. The candle must always be properly trimmed, and the determination must be made rapidly, so as not to haat the liquid to any extent. The most accurate work is obtained in a dark room, and the candle should be so placed as not to be subjected to a draft of air. The latter necessity renders the instrument absolutely impossible for use in the field.

Several forms of field apparatus in which the candle was employed as a source of light were attempted, but were entirely unsuccessful, and it was found necessary to resort to the electric light for field use.

THE GLECTRIC TURBIDIMETER.

This instrument was designed by the author for the use of the hydrorraphic branch of the United States Geological Survey, and is intended for fiold use only. Its construction is so regulated as to be exactly comparable with the candle turbidimeter, and the measuring tubes for each have been made interchangeable.

The electric turbidimeter as shown in fig. 1 consists of the same greduated glass tube as described for the candle turbidimeter, inclosed in a similar manner

a It has been found in actual field work that the end point in the electric turbidimeter, viz, the disappearance of the cross of light, is generally sharper and less subject to personal errors than the end point above designated. This is especially true when the two instruments are used by the same person, $i$. e., a common end point is more satisfactory. The Geological Survey has therefore placed the glass plate and cross disk in tha candle turbidimeter. 
by a brass holder $(A)$ open at the bottom. This holder is attached to the end of a brass cylinder $(m)$ containing a 2.5-volt dry battery $(C)$ and a 2.5-volt electric light $(d)$. Above the electric-light bulb, at a distance of 1 centimeter, is a disi of glass $(e)$ which is ground on the under side. Immediately above this is a brass disk ( $b$ ) 1 millimeter thick, through the center of which a cross is cut $(B)$. The lines in this cross are 0.5 millimeter wide. From the top of the brass plate to the bottom of the graduated glass tube the distance is just 1 centimeter.

To make a determination with the electric turbidimeter, first pour/ the turbid water to be tested back and forth from the glass tube to arother vessel until it is thoroughly mixed, and then turn on the light by adjusting the serew $(f)$ at the bottom of the instrument. Place the graduated glass tube in the holder, which has been screwed into place above the light, and pour the turbid water

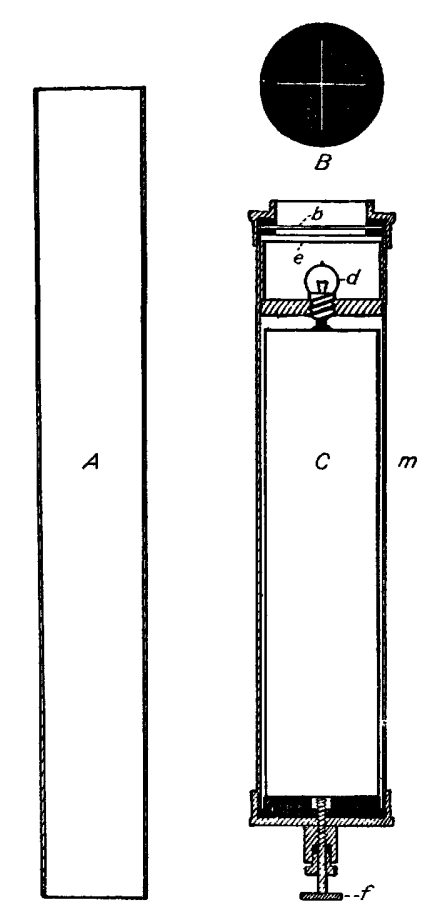

FIG. 1.-Jackson's electric turbidimeter.

into the tube until the cross of light just disappears. If the tube is not graduated directly in parts per million of silica, read the depth in millimeters of the water in the tube and refer to the table given later. In reading use the bottom of the meniscus as the reading point. In the lower part of the tube read past the disappearance of the sharp cross of light to the disappearance of the hazy cross of light. In this way the end point is the same as in the candle turbidimeter. Higher up in the tube there is only the sharp cross of light for an end point.

If the turbidity is above 100 parts per million use the short tub? $(25$ centimeters long). If the turbidity is between 100 parts and 25 parts per million the long tube $\mathbf{7 5}$ centimeters) may be emp'syed, but at any point below 100 the glass tube and the holder may be removed and the instrument lowered directly into the turbid water by means of a steel millimeter tape. Any degree of turbidity may be read in this manner provided the water is sufficiently deep.

If the water is shallow and below 25 turbidity, close estimations may be made by holding a bottle of the water toward the light and comparing it with the remembered appearance of standards of $5,10,15$, and 20 parts per million in bottles of the same size.

In the determination of turbidity with Jackson's turbidimeter many of the objections to the use of the United States Geological Survey turbidity rod are avoided. As the standard illumination is a part of the apparatus itself rather than the sun, none of the limitations which apply to the use of the rod, such as time of day, shade, etc., are necessary considerations. The instrument may be used at night if desired. As the sample to be tested is collected from the body of water under observation, inaccuracies due to moving water and yariations in turbidity caused thereby are avoided, and it is not

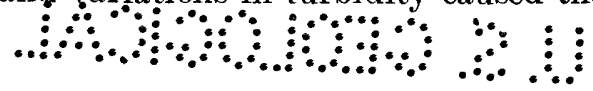


necessary to consider the depth of water in the river or lake under observation. In the use of the rod this is often a very troublesome feature, because, in case of low turbidity, there may not be water of sufficient depth to allow the rod to be submerged to the point of disappearance of the platinum wire. Another advantage is that tro end point in Jackson's turbidimeter is approached more sharply and the use of the instrument is not practically a test of the observer's eyesight, for the measurement of turbidity depends upon the obliteration of a beam of light, and not upon the definition of a certain object.

TESTS OF ELECTRIC TURBIDIMETER.

The Jackson electric turbidimeter is made up of several parts which it was necessary to test in order to determine their effect upon the accuracy of the instrument. These tests, made by Mr. R. B. Dole, assistant engineer, United States Geological Survey, under the direction of Mr. Daniel D. Jackson, are classified as follows:

1. Tests of the battery for current, electromotive force, and durability.

2. Tests of the electric bulb for intensity of light.

3 . Test of the ground-glass plate for opacity.

4. Calibration of the tube with silica standard.

5. Determination of the probable error.

6. Calibration of the tube with a sulphate standard. This vill be treated under the heading "Sulphates," on page 69.

Battery test.-The "Reliable" 2-cell battery, 6 inches long, was selected and tested, first for constant current and then for rec peration, by running it for one minute, alternating with a rest of five minutes. These tests, applied to three cartridges selected at random, resulted as follows:

Results of tests of 6-inch Q-cell "Reliable" battery.

BATTERY NO. 1.

\begin{tabular}{|c|c|c|c|c|}
\hline At end of-- & Current. & Loss. & E. M. F. & Light. \\
\hline 0 minute & $\begin{array}{l}\text { Ampere. } \\
0.250\end{array}$ & Ampere. & $\begin{array}{l}\text { Volts. } \\
2.66\end{array}$ & Bright. \\
\hline 1 minute & .245 & 0.005 & N. & \\
\hline 2 minutes $\ldots \ldots \ldots$ & .243 & .002 & & \\
\hline 3 minutes............... & .242 & .001 & & \\
\hline 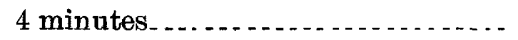 & .240 & .002 & & \\
\hline 5 minutes. & .240 & .000 & & \\
\hline 6 minutes. $\ldots \ldots \ldots$ & .238 & .002 & & \\
\hline 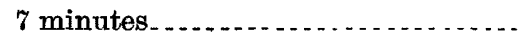 & .236 & .002 & & \\
\hline 8 minutes. & .235 & .001 & & \\
\hline 9 minutes. & .235 & .000 & & \\
\hline \multirow[t]{2}{*}{10 minutes. } & \multirow[t]{2}{*}{.235} & .000 & \multirow[t]{2}{*}{2.50} & \multirow[t]{2}{*}{ Bright. } \\
\hline & & .015 & & \\
\hline
\end{tabular}


Results of tests of 6-inch 2-cell "Reliable" battery-Continued. BATTERY NO. 1 AFTER A REST OF 90 MINUTES.

\begin{tabular}{|c|c|c|c|c|}
\hline At end of- & Current. & Loss. & E. M. F. & Light. \\
\hline 0 minute $\ldots . .$. & $\begin{array}{l}\text { Ampere. } \\
0.250\end{array}$ & Ampere. & $\begin{array}{l}\text { Volts. } \\
\quad 2.66\end{array}$ & Bright. \\
\hline 1 minute... & .245 & 0.005 & & \\
\hline 2 minutes.... & .243 & .002 & & \\
\hline 3 minutes . . . . . . . . & .241 & .002 & & \\
\hline 4 minutes... & .239 & .002 & & \\
\hline 5 minutes.. & .237 & .002 & & \\
\hline 6 minutes. . . & .236 & .001 & & \\
\hline 7 minutes.... & .235 & .001 & & - \\
\hline 8 minutes $\ldots . .$. & .235 & .000 & & \\
\hline 9 minutes $\ldots$ & .234 & .001 & & \\
\hline \multirow[t]{2}{*}{10 minutes } & .234 & .000 & \multirow[t]{2}{*}{2.50} & \multirow[t]{2}{*}{ Bright. } \\
\hline & & .016 & & \\
\hline
\end{tabular}

BATTERY NO. 2

\begin{tabular}{|c|c|c|c|c|}
\hline 0 minute $\ldots \ldots$ & 0.272 & & 2.80 & Bright. \\
\hline 1 minute $\ldots \ldots \ldots$ & .268 & 0.004 & & \\
\hline 2 minutes... & .265 & .003 & $\ldots$ & \\
\hline 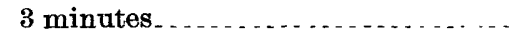 & .263 & .002 & & \\
\hline 4 minutes. $\ldots$ & .261 & .002 & & \\
\hline 5 minutes...... & .258 & .003 & & \\
\hline 6 minutes... & .255 & .003 & & \\
\hline 7 minutes. ... & .253 & .002 & & \\
\hline 8 minutes. . . . . . & .251 & .002 & & \\
\hline 9 minutes & .250 & .001 & & \\
\hline \multirow[t]{2}{*}{10 minutes } & \multirow[t]{2}{*}{.249} & .001 & \multirow[t]{2}{*}{2.63} & \multirow[t]{2}{*}{ Bright. } \\
\hline & & .023 & & \\
\hline
\end{tabular}

BATTERY NO. 2 AFTER A REST OF 90 MINUT

\begin{tabular}{|c|c|c|c|c|}
\hline 0 minute $\ldots \ldots \ldots$ & 0.263 & & 2.70 & Bright. \\
\hline 1 minute ............ & .258 & 0.005 & & \\
\hline 2 minutes. . . & .253 & .005 & & \\
\hline 3 minutes. . . . . . . & .252 & .001 & & \\
\hline 4 minutes $\ldots$ & .250 & .002 & & \\
\hline 5 minutes...... & .248 & .002 & & \\
\hline 6 minutes. & .246 & .002 & ... - & \\
\hline$\tau$ minutes $\ldots \ldots \ldots \ldots \ldots$ & .245 & .001 & & \\
\hline 8 minutes....... & .244 & .001 & & \\
\hline 9 minutes $\ldots$ & .243 & .001 & & \\
\hline \multirow[t]{2}{*}{ 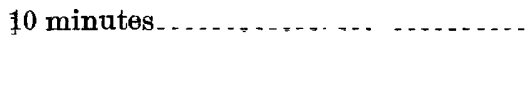 } & \multirow[t]{2}{*}{.243} & .000 & \multirow[t]{2}{*}{2.52} & \multirow[t]{2}{*}{ Bright. } \\
\hline & & .020 & & \\
\hline
\end{tabular}


Results of tests of 6-inch 2-cell "Reliable" battery-Continued.

BATTERY NO. 3.

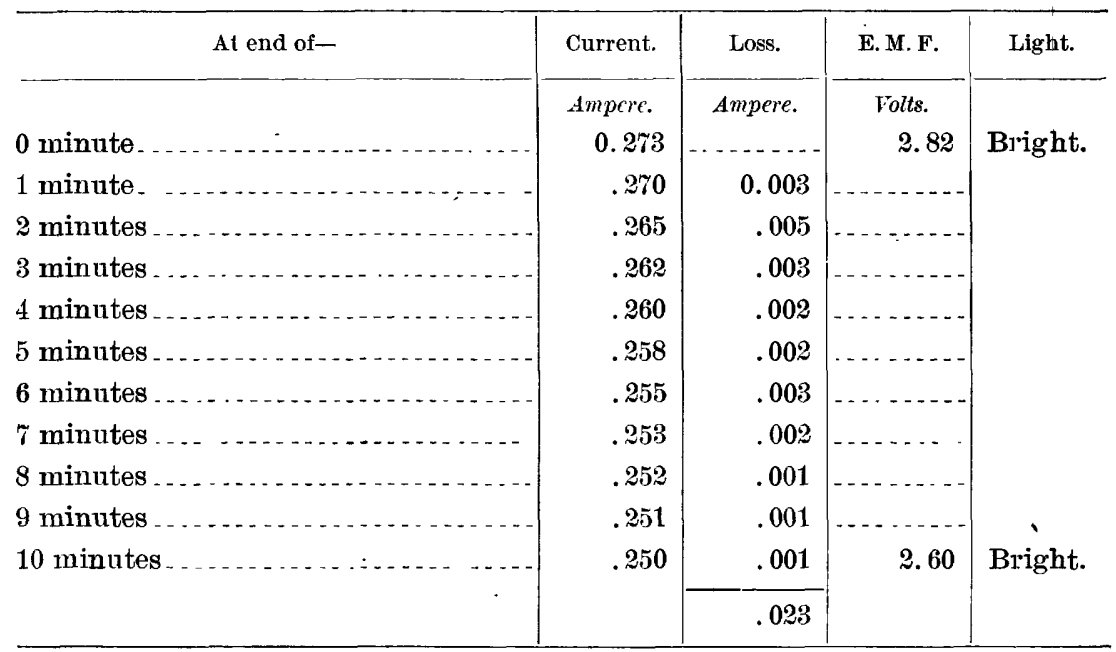

BATTERY NO. 3 AFTER REST OF 90 MINUTES.

\begin{tabular}{|c|c|c|c|c|}
\hline 0 minute. ....... & 0.256 & - & 2.70 & Bright. \\
\hline 1 minute. . . . . . & .252 & 0.004 & & \\
\hline 2 minutes $\ldots \ldots \ldots$ & .249 & .003 & & \\
\hline 3 minutes $\ldots \ldots$ & .246 & .003 & $\ldots$ & \\
\hline 4 minutes & .244 & .002 & & \\
\hline 5 minutes . . . . . & .243 & .001 & & \\
\hline 6 minutes. . . . . & .242 & .001 & - & \\
\hline 7 minutes $\ldots . . . . . .$. & .241 & .001 & & \\
\hline 8 minutes . . . . . . & .240 & .001 & & \\
\hline 9 minutes & .239 & .001 & & \\
\hline \multirow[t]{2}{*}{10 minutes } & .238 & .001 & 2.50 & Bright. \\
\hline & & .018 & & \\
\hline
\end{tabular}

The batteries were next tested for recuperation by alternatir $\mathrm{g}$ one minute of use with five minutes of rest, as follows:

BATTERY NO. 1.

\begin{tabular}{|c|c|c|c|c|c|c|}
\hline Period. & $\begin{array}{c}\text { Initial } \\
\text { current. }\end{array}$ & $\begin{array}{c}\text { Final } \\
\text { current. }\end{array}$ & $\begin{array}{l}\text { Drop in } \\
\text { current. }\end{array}$ & $\begin{array}{c}\text { Initial } \\
\text { voltage. }\end{array}$ & $\begin{array}{c}\text { Final } \\
\text { voltage. }\end{array}$ & $\begin{array}{l}\text { Drop in } \\
\text { roltage. }\end{array}$ \\
\hline First minute & $\begin{array}{c}\text { Ampere. } \\
0.243\end{array}$ & $\begin{array}{c}\text { Ampere. } \\
0.238\end{array}$ & $\begin{array}{c}\text { Ampere. } \\
0.005\end{array}$ & 2.60 & 2.54 & 0.06 \\
\hline Second minute.... & .242 & .237 & .005 & 2.56 & 2.51 & .05 \\
\hline Third minute.... & .241 & .237 & .004 & 2.56 & 2.50 & .06 \\
\hline Fourth minute $\ldots .$. & .240 & .238 & .002 & 2.56 & 2.50 & .06 \\
\hline Fifth minute $\ldots \ldots \ldots$ & .240 & .236 & .004 & 2.57 & 2.50 & .07 \\
\hline
\end{tabular}


BATTERY NO. 2.

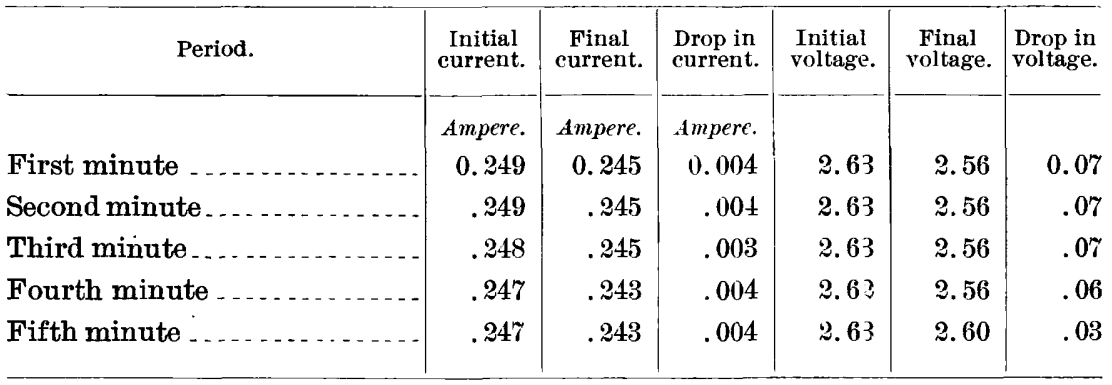

BATTERY NO. 3.

\begin{tabular}{l|r|r|r|r|r|r}
\hline First minute $\ldots \ldots$ & 0.260 & 0.255 & 0.005 & 2.73 & 2.66 & 0.10 \\
Second minute $\ldots \ldots$ & .257 & .253 & .004 & 2.72 & 2.66 & .06 \\
Third minute $\ldots \ldots$ & .255 & .251 & .004 & 2.79 & 2.63 & .07 \\
Fourth minute & .254 & .250 & .004 & 2.79 & 2.63 & .07 \\
Fifth minute $\ldots . . .253$ & .249 & .004 & 2.63 & 2.60 & .06 \\
\hline
\end{tabular}

Highest voltage observed

Lowest voltage observed._._.

Extreme variation

Reckoned on an average voltage of 2.66 volts, this is a variation of 12 per cent.

Highest amperage observed

Lowest amperage observed_._._. 234

Maximum variation

Reckoned on an average amperage of 0.248 ampere this is a variation of 16 per cent in current. The drop in current averages 0.002 ampere per minute, or about 0.8 per cent.

It will be seen from these results that the battery is quick in recovery and that while in use the reduction in electromotive force is comparatively small. The change in current observed in the batteries tested does not cause any error in a turbidity estimation. Readings were made at different times with a standard of turbidity corresponding to 250 parts per million of silica, and in every case the variation in depth of liquid read in the graduated tube came within the probable deviation occurring in reading. The ordinary varia'tion of current in the battery does not affect the accuracy of the instrument to a measurable degree.

This battery will remain effective under ordinary conditions from fifty to sixty days, at the end of which time it is advisable to change: the cartridge, 
Electric-bulb test.-Several lights were tested to see if there were a noticeable deviation in the intensity of light produced. The test of four sample lights is here given:

\begin{tabular}{|c|c|c|c|c|}
\hline Battery. & $\begin{array}{l}\text { Lamp } \\
\text { No.1. }\end{array}$ & $\begin{array}{l}\text { Lamp } \\
\text { No.2. }\end{array}$ & $\begin{array}{l}\text { Lamp } \\
\text { No. } 3 .\end{array}$ & $\begin{array}{l}\text { Lamp } \\
\text { No. } 4 .\end{array}$ \\
\hline No. $1 \ldots$ & 8.7 & 8.5 & 8.4 & $\tau . \tau$ \\
\hline No. $2 \ldots$ & 8.6 & 8.6 & 8.2 & 8.0 \\
\hline No. 3. & 8.9 & 8.5 & 8.3 & 7.9 \\
\hline
\end{tabular}

The numbers given are the depths in centimeters produced by using a standard turbidity of 250 with different batteries and lights. The mean of these observations is 8.4 , while the average deviation from the mean is 0.3 , which brings three of the lamps within the limit allowed on individual readings under constant conditions; the fourth light, however, falls without the limit of error. The lamps were chosen at random from a stock of 2.5 -volt lights. It is evident that here is a variation which must be overcome. It may be done by buying a large stock of lamps and selecting only such as come within the standard conditions, or by buying lamps of guaranteed candle power. In conclusion it may be said that it is well to test a new lamp with silica standard before using it in the field.

Glass-plate test.-The glass diaphragm placed over the lamp is ground on one side in order to tone and diffuse the rays from the electric light. It also makes possible the use of a much shorter glass tube than would otherwise be necessary, and it reduces variation in candlepower in the effect thereof on turbidity determinations. It appears to be possible to procure glasses which are ground to the same opacity. Different glasses were tried in the instrument without any apparent effect on the depth of turbid liquid required to shut off the light. It may be said in connection with the ground glass that the cross slit of brass above it should be constant in width of aperture. As this offers no mechanical difficulties, no experiments were made to determine the effect of variation in the width of the slit.

Calibration for turbidity.-When work was begun on the calibration of the instrument it was necessary to prepare a standard silica solution. The standard heretofore used has been very difficult to match on account of the difficulty of grinding the silica fine enough to reach the required turbidity. The standard is such that it gives a reading of 500 parts per million at a depth of 4.5 centimeters, while the standard prepared by ordinary grinding gives a reading of 500 parts per million at a depth of about 5.7 centimeters. Several

IRR $151-05-3$ 
careful grindings failed to give the decired reading of 4.5 centimeters. It was therefore decided to make some very careful grindings and to select as a standard the one giving the lowest reading in depth with the turbidimeter. It was found that the particles of silica need to be rubbed apart with the finger after being ground, in order to secure the maximum turbidity. It is of interest to note the various readings with the four standard solutions prevared.

Variations in turbidity readings with different degrees of fineness of silica.

DEPTH, IN CENTIMETERS, PRODUCED WITH 500 STANDARD.

\begin{tabular}{|r|r|r|r|}
\hline $\begin{array}{c}\text { Standard } \\
\text { No. 1. }\end{array}$ & $\begin{array}{c}\text { Standard } \\
\text { No. 2. }\end{array}$ & $\begin{array}{c}\text { Standard } \\
\text { No. 3. }\end{array}$ & $\begin{array}{c}\text { Standard } \\
\text { No. 4. }\end{array}$ \\
\hline 5.7 & 5.3 & 4.4 & 6.1 \\
5.6 & 5.4 & 4.6 & 6.0 \\
5.6 & 5.3 & 4.5 & 6.1 \\
5.7 & 5.2 & 4.4 & 6.1 \\
\hline$a 5.6$ & $a 5.3$ & $a 4.5$ & $a 6.1$ \\
\hline
\end{tabular}

DEPTH, IN CENTIMETERS, PRODUCED WITH 250 STANDARD.

\begin{tabular}{|r|r|r|r|}
\hline 10.2 & 10.2 & 8.6 & 11.0 \\
10.2 & 9.7 & 8.5 & 11.1 \\
10.1 & 9.9 & 8.6 & 11.0 \\
10.2 & 10.0 & 8.7 & 11.0 \\
\hline$a 10.2$ & $a 10.0$ & $a 8.6$ & $a 11.0$ \\
\hline
\end{tabular}

DEPTH, IN CENTIMETERS, PRODUCED WITH 125 STANDARD.

\begin{tabular}{|r|r|r|r|}
\hline 20.0 & 19.8 & 16.7 & 21.7 \\
20.3 & 19.6 & 16.9 & 21.5 \\
20.5 & 19.9 & 17.0 & 22.0 \\
20.5 & 20.1 & 17.1 & $21 . \varepsilon$ \\
\hline$a 20.3$ & $a 19.8$ & $a 16.9$ & $a 21 . \varepsilon$ \\
\hline
\end{tabular}

a Average.

According to these readings it was found that solution No. 3 practically coincides with the old standard and was therefore used as standard. It is believed that this choice will result in less confusion in the future when a new standard solution is desired, because this chosen turbidity represents the limit in grinding.

The work of calibration consisted in taking reading with different dilutions of the silica standard. After thoroughly shaking the stand- 
ard it was poured into the graduated tube until the depth was reached at which the cross of light disappeared. Precautions were taken to secure uniform conditions of light, and the battery was tested for current at frequent intervals. In the following tables the actual readings of the tube are given, after which the average and average deviation are stated. Observations deviating by more than the average deviation are then discarded and the average of the remairder is taken to determine the resultant point on the curve which represents the turbidity scale.

Calibration of turbidimeter for standard of 250 parts per million turbidity.

[Centimeters. Excess of average deviation indicated by italic figures.]

\begin{tabular}{|r|r||r|r|}
\hline Reading. & Deviation. & Reading. & Deviation. \\
\cline { 1 - 4 } 9.2 & 0.5 & 8.6 & 0.1 \\
8.4 & .3 & 8.4 & .3 \\
8.7 & .0 & 8.8 & .1 \\
8.9 & .2 & 8.4 & .3 \\
8.5 & .2 & 8.4 & .3 \\
9.2 & .5 & 9.2 & .5 \\
8.4 & .3 & 8.4 & .3 \\
8.7 & .0 & 8.7 & .0 \\
8.9 & .2 & 8.9 & .2 \\
8.5 & .2 & 8.5 & .2 \\
8.6 & .1 & 8.8 & .1 \\
8.8 & .1 & 8.9 & .2 \\
8.9 & .2 & 8.7 & .0 \\
9.0 & .3 & 8.5 & .2 \\
8.7 & .0 & 269.9 & 6.2 \\
8.8 & .1 & & \\
8.5 & .2 & & \\
\hline
\end{tabular}

Mean $=269.9 \div 31=8.7$. Average deviation $=6.2 \div 31=0.2$.

It will be noted that 10 of 31 readings differ from the mean by an amount greater than the average deviation $(0.2)$. Only 3 readings have a deviation greater than 0.3. It is therefore assumed that under ordinary conditions a variation of 0.3 centimeter at 250 standard should be allowed. 
Calibration of turbidimeter for standard of 200 parts per million turbidity.

[Centimeters. Excess of average deviation indicated by italic figures.]

\begin{tabular}{|r|r||r|r|}
\hline Reading. & Deviation. & Reading. & Deviation. \\
\hline 11.3 & 0.3 & 10.6 & 0.4 \\
11.1 & .1 & 11.3 & .3 \\
11.1 & .1 & 11.1 & .1 \\
11.0 & .0 & 11.1 & .1 \\
11.0 & .0 & 11.0 & .0 \\
10.9 & .1 & 11.0 & .0 \\
11.5 & .5 & 10.9 & .1 \\
10.6 & .4 & 187.3 & 2.9 \\
11.1 & .1 & & \\
10.7 & .3 & & \\
\hline
\end{tabular}

Mean $=187.3 \div 17=11.0$. Average deviation $=2.9 \div 17=0.2$.

The deviation of 6 of the 17 observations exceeds 0.2 centimeter, the average deviation. Only 3 observations exceed 0.3 centimeter in deviation. Under ordinary circumstances we may consider 0.3 centimeter as the average deviation.

Calibration of turbidimeter for standard of 100 parts per million turbidity.

[Centimeters. Excess of average deviation indicated by italic figures.]

\begin{tabular}{|r|r||r|r|}
\hline Reading. & Deviation. & Reading. & Deviation. \\
\hline 21.9 & 0.2 & 21.9 & 0.2 \\
21.5 & .2 & 22.2 & .5 \\
21.6 & .1 & 21.0 & .7 \\
21.1 & .6 & 21.9 & .2 \\
22.2 & .5 & 21.5 & .2 \\
21.0 & .7 & 21.9 & .2 \\
21.9 & .2 & 303.1 & 4.7 \\
21.5 & .2 & & \\
\hline
\end{tabular}

Mean $=303.1 \div 14=21.7$. Average deviation $=4.7 \div 14=0.3$.

The deviation of 5 of the 14 observations exceeds 0.3 centimeter, the average deviation. Probably 0.4 centimeter would be the ordinary deviation. If we reckon 0.4 as the average deviation, mean $=$ 21.8. Probably 21.7 is correct. 
Calibration of turbidimeter for standard of 125 parts per million turbidity.

[Centimeters. Excess of average deviation indicated by italic figures.]

\begin{tabular}{|r|r||r|r|}
\hline Reading. & Deviation. & Reading. & Deviation. \\
\hline 17.3 & 0.0 & 17.2 & .1 \\
16.7 & .6 & 17.5 & .2 \\
17.2 & .1 & 17.4 & .1 \\
17.4 & .1 & 155.6 & 1.5 \\
17.3 & .0 & & \\
17.6 & .3 & & \\
Mean $=\mathbf{1 5 5 . 6} \div 9=17.3$. & Average deviation $=1.5 \div 9$
\end{tabular}$=0.2$.

The average deviation from 9 readings is 0.2 centimeter and is exceeded by only 2 readings. Probably more readings would give greater deviations and the average deviation would be increas?d.

Calibration of turbidimeter for standard of 500 parts per million turbidity.

[Centimeters. Excess of average deviation indicated by italic figures.]

\begin{tabular}{|r|r||r|r|}
\hline Reading. & Deviation. & Reading. & Deviation. \\
\hline 4.4 & 0.1 & 4.6 & .1 \\
4.6 & .1 & 4.5 & .0 \\
4.5 & .0 & 31.4 & .5 \\
4.4 & .1 & & \\
4.4 & .1 & & \\
\hline
\end{tabular}

Though only 7 readings are here given, many more were taken without getting anomalous results. The probable deviation is 0.1 centimeter and will not be exceeded. Mean $=4.5$ centimeters.

Turbidity of 1,000 parts per million.-From many observations at different times, 2.3 centimeters is the reading for 1,000 standard.

Average deviation $=0.1$ centimeter.

Mean $\quad=2.3$ centimeters.

We have, then, determined by actual experiment the depth corresponding to 6 turbidities;

$\begin{array}{lrrrrrr}\text { Turbidity - } & 100 & 125 & 200 & 250 & 500 & 1,0 \Upsilon 2 \\ \text { Depth (centimeters) -- } & 21.7 & 17.3 & 11.0 & 8.7 & 4.5 & 2.3\end{array}$


These points are then plotted on logarithmic cross-section paper (fig. 2) and intermediate points determined by measurement on the plot.

Below 100, depths have been determined at 50 and at 25 by using a longer tube, with which the effect will be the same as lowering the light into the standard by means of a tape. The observations made

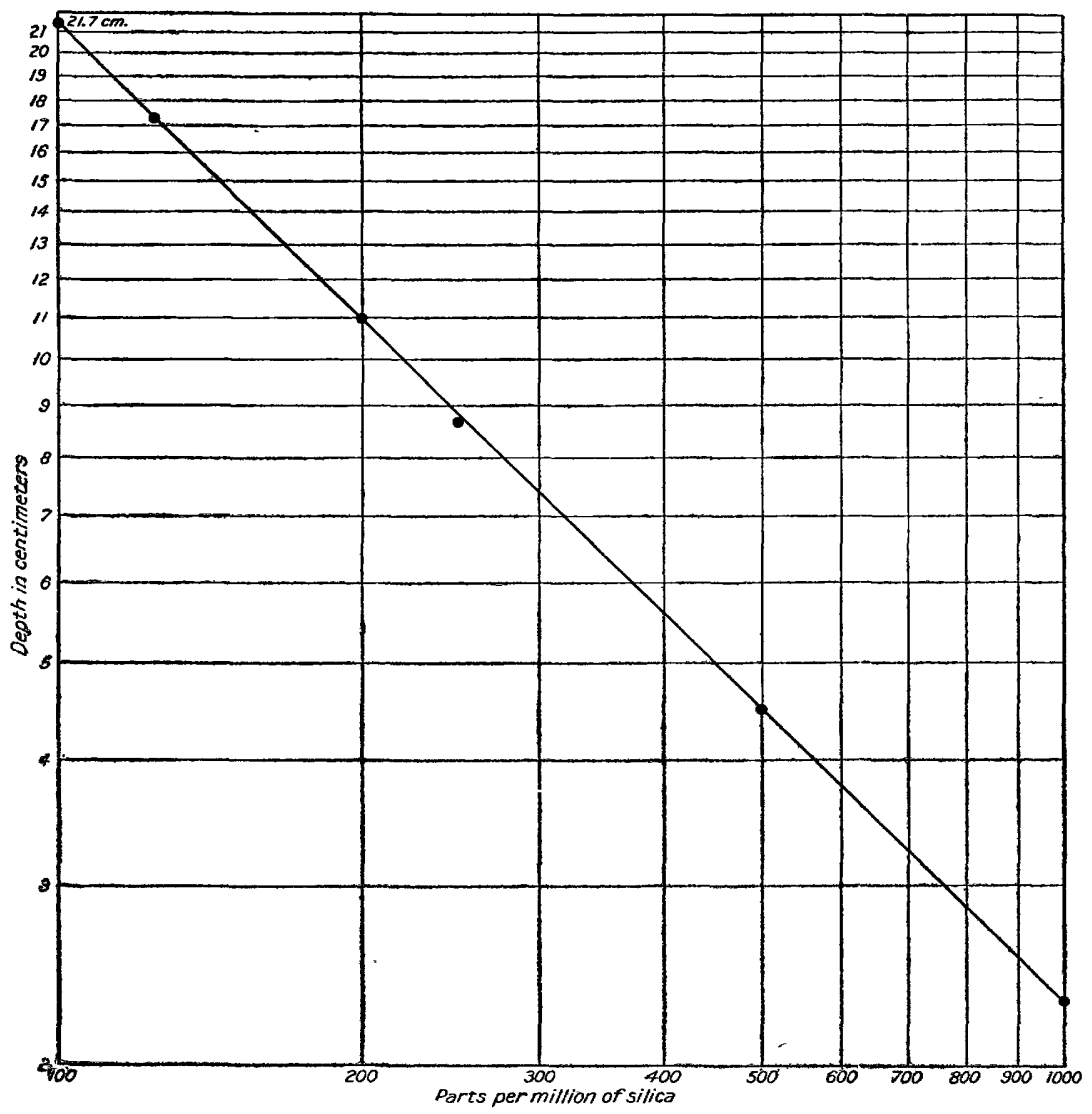

FIG. 2.-Logarithmic scale of turbidity.

at 50 and 25 seem to indicate that the curve begins to swing away from its course at 100 . This change may be due to the fact that the distance between light and eye is increased. From 1,000 to 100 the light is 25 centimeters from the eye; at 50 it is 40 centimeters away, while at 25 the distance is 65 centimeters. The readings are as follows: 
LEIGHTON.]

SUSPENDED MATTER.

Calibration of turbidimeter for standard of 50 and 25 parts per million turbidity.

[Centimeters.]

\begin{tabular}{|c|}
\hline 50 parts. \\
\hline 36.1 \\
34.0 \\
34.5 \\
34.4 \\
35.3 \\
35.0 \\
34.3 \\
34.1 \\
33.9 \\
35.2 \\
\hline 346.8 \\
\hline
\end{tabular}

[Centimeters.]

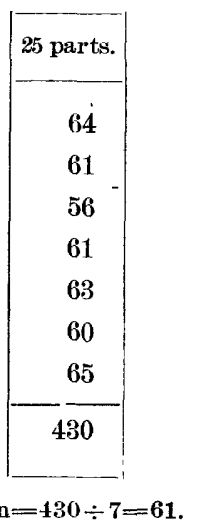

Mean $=346.8 \div 10=34.7$.

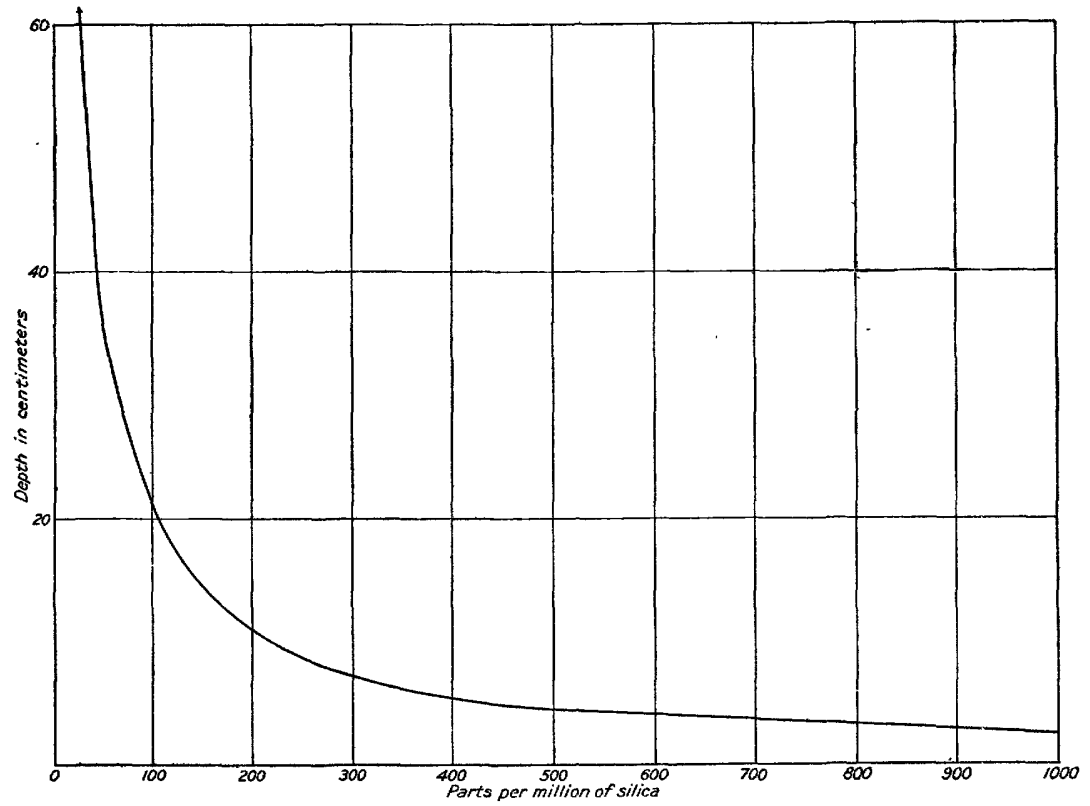

FIG. 3.-Turbidity curve. 
These readings may not be accurate. Further experiments may show that they are too low. At most, however, they are within 10 parts per million of silica in their relation to the real values (fig. 3). The limit of accuracy between 100 and 1,000 is well defined from the points determined.

From the values heretofore determined the depths of liquid in the turbidimeter corresponding to a silica standard of turbidity are set forth in the following table:

Turbidity determinations.

\begin{tabular}{|c|c|c|c|}
\hline Depth. & Silica. & Depth. & Silica. \\
\hline $\mathrm{C} m$. & $\begin{array}{l}\text { Parts per } \\
\text { million. }\end{array}$ & $C m$ & $\begin{array}{l}\text { Parts per } \\
\text { million. }\end{array}$ \\
\hline 2.3 & 1,000 & 10.5 & 210 \\
\hline 2.6 & 900 & 11.0 & 200 \\
\hline 2.9 & 800 & 11.5 & 190 \\
\hline 3.2 & 700 & 12.1 & 180 \\
\hline 3.5 & 650 & 12.8 & 170 \\
\hline 3.8 & 600 & 13.6 & 160 \\
\hline 4.1 & 550 & 14.4 & 150 \\
\hline 4.5 & 500 & 15.4 & 140 \\
\hline 4.9 & 450 & 16.6 & 130 \\
\hline 5.6 & 400 & 18.0 & 120 \\
\hline 6.3 & 350 & 19.6 & 110 \\
\hline 7.3 & 300 & 21.7 & 100 \\
\hline 7.6 & 290 & 23.0 & 90 \\
\hline 7.8 & 280 & 25.0 & 80 \\
\hline 8.1 & 270 & 28.0 & 70 \\
\hline 8.5 & 260 & 31.0 & 60 \\
\hline 8.7 & 250 & 35.0 & 50 \\
\hline 9.1 & 240 & 42.0 & 40 \\
\hline 9.5 & 230 & 52.0 & 30 \\
\hline 10.0 & 220 & 70.0 & 20 \\
\hline
\end{tabular}

DETERMINATION OF THE PROBABLE ERROR.

Readings on the same standard solution with the same battery and light by the same person will vary within narrow limits. These limits have been determined for several points and calculated as average deviation. 
Limits of accuracy on duplicate readings.

\begin{tabular}{|c|c|c|}
\hline Standard. & $\begin{array}{l}\text { Average devi- } \\
\text { ationin centi- } \\
\text { meters. }\end{array}$ & Limit of accuracy in parts per million. \\
\hline 1,000 & 0.1 & Reading correct within 35 parts. \\
\hline 500 & .1 & Reading correct within 15 parts. \\
\hline 250 & .3 & Reading correct within 10 parts. \\
\hline 200 & .3 & Reading correct within 8 parts. \\
\hline 100 & .4 & Reading correct within 5 parts. \\
\hline 50 & & Reading correct within 5 parts. \\
\hline 30 & & Reading correct within 5 parts. \\
\hline
\end{tabular}

In other words, a turbidity between 500 and 1,000 parts can be measured accurately within 35 parts. Between 200 and 50') parts measurement can be made within 10 to 15 parts, and between 50 and 200 within 5 to 8 parts per million.

The limit of accuracy is not changed by change of observers. Since the thing seen is a ray of light, it appears to be visible to any eye and appears to be shut off at the same depth for different observers.

The limit is greater than that change in depth caused by normal variations in the current. Therefore the limit of accuracy is not increased by variations in the battery within ordinary limits.

Changes in the electric bulb can introduce a constant error greater than the probable error in determination. Therefore onl r such Iamps should be used as have been tested with a standard silica solution.

In the general field work of the hydrographic branch the field assistants and those cooperating are instructed to use the Jackson turbidimeter in connection with all waters having a turbidity of more than 100 , while the turbidity rod could be used in waters having a lower turbidity. The objections mentioned in connection with the use of this rod are not so serious in the determination of low turbidities.

\section{COLOR.}

\section{OCCURRENCE.}

The term "color" as used in water chemistry should not be confounded with the term as ordinarily used. The streams of the Mississippi Valley, and indeed the great river itself, appear highly colored. One will find rivers which are habitually red, yellow, brown, or black in appearance. This color is not due to the water itself, but to the character of the matter which is carried in suspension. It is 8 factor of the turbidity, and reveals the nature of the geologic formations eroded by the flowing water. On the other hand, waters may have a 
color due to dissolved substances, and this is the feature referred to by the term as used in water analysis.

In those parts of the United States where the undorlying rock is resistant-that is, where it does not readily break up and disintegrate under the forces of erosion-we usually find colored water. At first sight it seems paradoxical that the clear waters of New England, many of which drain from granitic formations and hills of gravel, are colored, while those of the Central West, which carry large amounts of suspended matter eroded from the surface, are, when freed from turbidity, nearly colorless. In many cases this is due to the fact that the substances in suspension are of such nature th at they absorb any color which might have been dissolved. On the other hand, in New England streams the color due to the decay of regetable matter, such as peat or muck, remains in solution, and while tl e water is generally very clear the color itself is apparent in varying degrees.

The importance of the color determination arises from the fact that in public supplies consumers demand a clear, colorloss liquid, and are reluctant to accept any other. In manufacturing processes a colored water often works harm. In certain classes of waters the dissolved color is a fair index of the amount of organic matter contained. These facts pertain primarily to unpolluted water, for it is apparent that a water contaminated by wastes may have colors arising from sources such as dyes, sediments, etc. On the whole, the color of a natural water which can be applied to domestic and manufacturing purposes affects its value along economic lines. The periodical determination of dissolved color is necessary, as its intensity varies. with the seasons and is influenced by sunlight, precipitation, and various other natural phenomena.

COLOR STANDARDS.

\section{GEOLOGICAL SURVEY STANDARD.}

The standard of color determinations adopted by the United States Geological Survey is known as the platinum-cobalt method, devised by Mr. Allen Hazen, from whom so many practical and extremely valuable ideas with reference to the determination of quality of water have come.

The method is as follows:

A standard solution which has a color of 500 is made by dissolving 1.246 grams potassium-platinic chloride ${ }^{a}\left(\mathrm{PtCl}_{4}, 2 \mathrm{KCl}\right)$, containing 0.5 gram platinum, and 1 gram of crystallized cobalt chloride $\left(\mathrm{CoCl}_{2}, 6 \mathrm{H}_{2} \mathrm{O}\right)$, containing 0.25 gram of cobalt in water, with

a Potassium-platinous chloride is a salt that is often substituted by dealers in place of the potassium-platinic chloride. It is sometimes incorrectly labeled. The platinous salt has a reddish color, while the platinic salt has a yellow color. 
100 cubic centimeters concentrated hydrochloric acid, and mal-ing up to 1 liter with distilled water. By diluting this solution, stendards are prepared having values of $0,5,10,15,20,25,30,35,40,50,60$, and 70 . The numbers correspond to the metallic platinum in the solutions in parts per million. These are kept in 100 c. c. Nessler jars of such diameter that the liquid shall have a depth between 20 and 25 centimeters and shall be protected from dust. The color of a sample is observed by filling a similar tube with water and compering it with the standards. The observation is made by looking vertically downward through the tubes upon a white surface placed at such an angle that light is reflected upward through the column of liquid. The reading is recorded to the nearest unit. Waters that. have a color darker than 70 are diluted before making the comparison, in order that no difficulties may be encountered in matching the hues. Water containing matter in suspension is filtered until no visible turbidity remains. If the suspended matter is coarse, filter paper may be used for this purpose; if the suspended matter is fine, the use of the Berkfeld filter is recommended. The use of a Pasteur filter is to be avoided, as it exerts a decolorizing action.

It is impracticable to carry the standard tubes above described into the field for observations, and yet field observations are of great convenience and value to the sanitary engineer, and in general to the investigations of the United States Geological Survey.

FIELD STANDARDS.

DESCRIPTION.

Disks of colored glass have been prepared by Mr. Allen Hazen, in cooperation with the Survey, as standards for measuring color of water in the field. ${ }^{a}$ These disks have been rated by Mr. George C. Whipple to correspond with the platinum-cobalt standard. The color is measured by balancing the color of the water in a metallic tube with glass ends against the colors of glass disks of known value. The number on each disk represents the corresponding color of a water. This is not a new standard, but a new application of an old standard. The glass disks are rated to correspond with the platinum-cobalt color standard. The process bears the same relation to the usual laboratory process that an aneroid barometer bears to a mercurial barometer. The metallic tubes and glass standards are more portable and better adapted to field use than the Nessler tubes and color solutions heretofore used. The standards are disks of amber-colored glass, mounted with aluminum. Each disk carries two numbers. One sumber is over 100, and is a serial number for the purpose of ide itif cation.

- Pressey, H. A., Observations on flow of rivers in vicinity of New York City : WaterSup. and Irr. Paper No. 76, U. S. Geol. Survey, 1903, PI. X. 
The other number is less than 100, and shows the colnr value of the disk; that is to say, the color of each disk is equal to the color of a solution of the designated number of parts per million of platinum with the required amount of cobalt to match the hue when seen in a depth of 200 millimeters. When a water comes between two disks its value can be estimated between them by judgment. Two or more disks can be used, one behind the other, in which case their combined value is the sum of the individual values. By combining the disks of a series in different ways a considerable number of values can be produced, allowing the closer matching of many waters.

USE OF FIELD STANDARDS.

Filling the tubes.-The tube, having an aluminum stopper, is to be filled with water, the color of which is to be determined. Rinse the tube once or twice by filling and emptying it. The serond tube, having the clips to hold the glass disks, is made much like the one holding the water, to facilitate comparison. Theoretically tl is tube should be filled with distilled water. Practically it makes very little difference whether it is filled with distilled water or empty. Use distilled water when it is convenient to do so, and when distilled water of unquestionable quality is at hand; otherwise wipe the inside of the tube dry to prevent fogging of the glass ends, and proceed with the tube empty.

Holding the tubes.-Hold the tubes at such a distanse from the eye that the sides of the tubes just can not be seen. This occurs when the near end of the tube is 8 or 9 inches from the eye. Hold the tubes at such an angle that both can be seen at once with one eye. Good results can not be obtained in any other way. Intercl nnge the tubes once or twice, as sometimes the light on the right and left is not quite equal.

Background.-There should be a clear white background with a strong illumination. The best results can not be obtained with either too little or too much light. In a gray day look at tl. sky near the horizon away from the sun. In a bright day look at a piece of white paper or tile upon which a strong light falls. The white surface may be vertical and the tubes held horizontally, or the tubes may be held at an angle directed downward toward a hor zontal surface, as may be most convenient. Good results can not be obtained by artificial light.

Turbid water.-The colors of very turbid waters can not be measured in this way. Slight turbidities do not interfere seriously with the results. Waters too turbid for direct observations should be filtered through thick filter paper before being tested; and in case the suspended matter causing the turbidity is fine in grain and large 
in amount, even this method may fail. The turbidity of water should be taten as far as possible in connection with color observations, except in cases where it is obvious from inspection that there is practically no turbidity.

Highly colored waters.-Some waters will be found having a higher color than can be matched by the standards. In general, waters with colors above 100 should not be matched in 200-millimeter tubes, and the results with waters having colors below 80 will be considerably more accurate than with more highly colored ones. Two procedures are possible with waters having higher colors; namely, to dilute with distilled water before measuring the color, or to use shorter tubes. The latter procedure is the more conveniont, but both are equally accurate. To measure the color with short tubes, put the highly colored water in a tube of one-half the usual length and match as usual. It is not necessary to have a short 'standard holder. The 200-millimeter tube can be used. After the water is matched the result is multiplied by 2 . In case the color is too high to be read in a 100-millimeter tube it can be put in a 50 -millimeter tube, and the result multiplied by 4 . When dilution is used the highly colored water is mixed with one or more volumes of distilled water, the color matched, and the result multiplied by a corresponding factor. The tube itself can be used for measuring the colored water and the distilled water, and the mixing can be done in a tumbler or any convenient clean vessel.

Cleaning the tubes.-Always keep the tubes clean. Take particular care of the glass ends. All the ends are removable for the purpose of cleaning, and should not be screwed on too tightly. They should be water-tight when screwed up only loosely, for if screwed on hard they may stick so as to come off with difficulty.

\section{IRON.}

One of the important determinations which it is neces ary to include in many special investigations is that of iron. Water containing an appreciable amount of this metal can not be used in many manufacturing processes. It is objectionable in domestic uses by reason of its taste and the discoloration of linen. Certain solutions of iron in boiler feed waters are particularly destructive. Iron in ground waters stimulates the growth of Crenothrix, which frequently clogs water pipes. On the other hand, iron has a certain medicinal value, and when it is in the form of sulphate has valuable coagulating properties. The last-named effect is well demonstrated in streams draining coal regions. ${ }^{a}$

a Leighton, M. O., Quality of water in Susquehanna River drainage basin : V'ater-Sup. and Irr. Paper No. 108, U. S. Geol. Survey, 1904, p. 36. 
Colorimetric methods are believed to be the simplest and best for the determination of iron in natural waters, and they readily lend themselves to modification for field purposes. That which involves the use of potassium ferrocyanide, described on page 226 of Sutton's Volumetric Analysis, ninth edition, was selected as best adapted for the purposes in view. The process involves the addition of acid and KCNS to the water under investigation or to the resicual solution of that water, thereby producing a characteristic blood-red color. The depth of this color is absolutely fixed by the amount of iron in the water. It is then necessary to add to a sinilar mixture, made up with distilled water, such a quantity of standard iron solution as will produce in this solution exactly the same shade of red as is shown in the water under investigation. Then from the amount of standard iron solution used to produce that shade of red the amount of iron in the water under investigation may easily be determined.

The modification of this method for field purposes consists of the use of fixed color standards, each having been previously rated to correspond with some known equivalent of iron. The apparatus used in the work is that already described for the determination of natural color. (Pl. II.) The color standards are red glass disks, rated and used in precisely the same way as the natural color standards. The colored light is transmitted directly through the disk tube, and the disks may be changed or combined until the color of the sample under examination is matched. Then from the rating of the disks the amount of iron may be stated.

A sample of the clear water to be tested is poured into a 50- or 100c. c. graduate to the 45 c. c. mark, 2 cubic centimeters of concentrated nitric acid added, and the contents thoroughly mixed in order to convert all ferrous iron present into ferric iron. The fluid should then be allowed to stand about minutes.

The mixing and oxidation is preferably accomplished by pouring the solution from the graduate into another vessel, such as the glass turbidimeter tube, and vice versa, at least eight or ten times. To the acidified solution in the graduate is then added 3 cubic centimeters of a solution of potassium sulphocyanide containing 20 grams. KCNS per liter, and the liquids are thoroughy. mixed and yangapen mon The solution is now transferred to the aluminum colorimeter tube, which has a capacity of about 45 cubic centimeters and is about 8 inches long.

Nitric acid is used in the above method instead cf hydrochloric acid, commonly employed, in the first place to avoid any corrosion of the aluminum tube, the desirability of the use of which will be explained later. With the employment of nitric acid instead of hydrochloric acid, moreover, it was discovered that the color produced in 


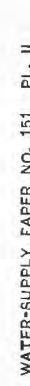
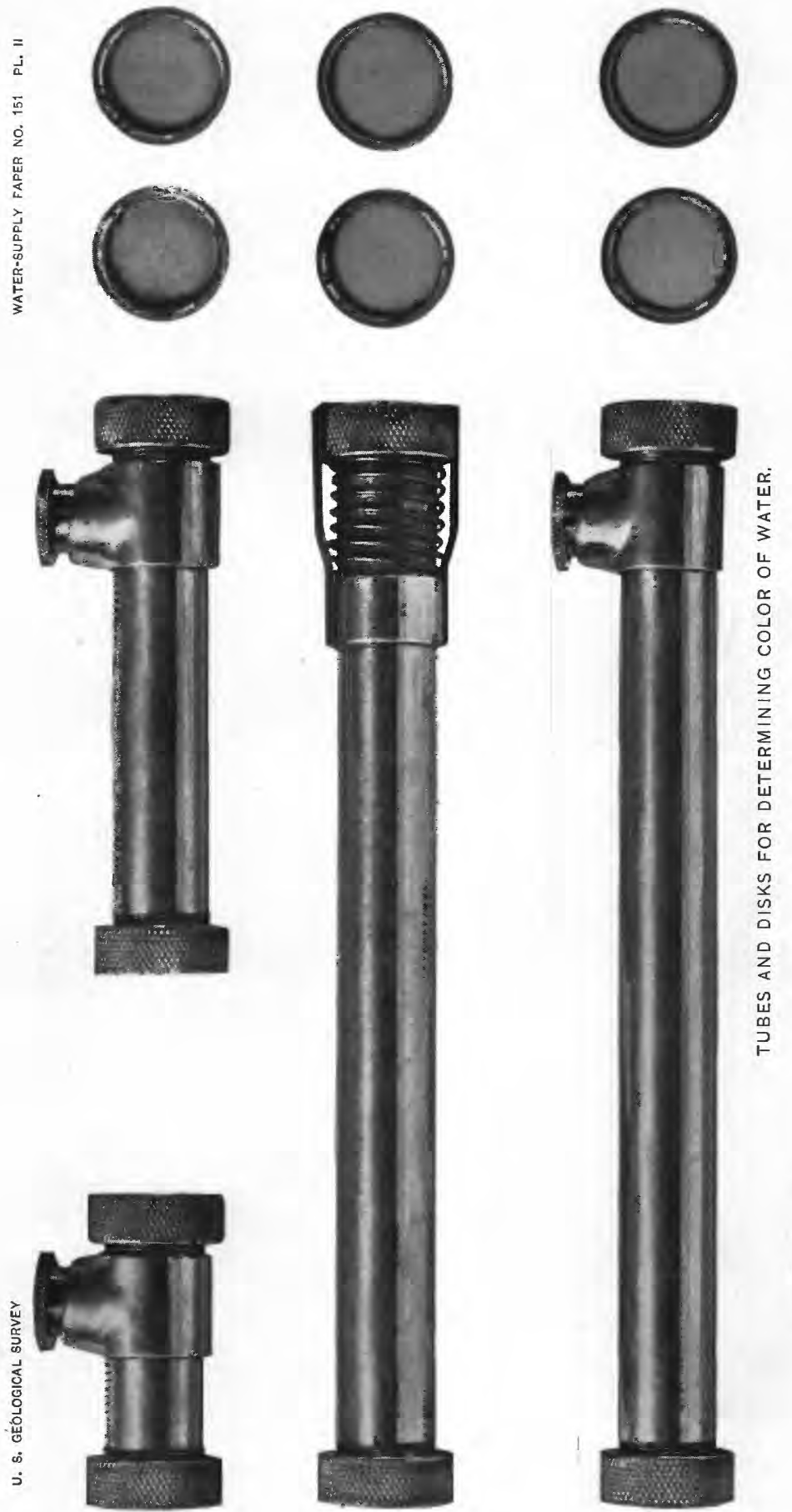
iron solutions by the addition of sulphocyanide is somewhat deeper and does not fade nearly so rapidly. Finally, the addition of nitric acid not only effects the required acidity of the solution essential to the test, but obviates the need of employing potassium permanganate in order to convert any ferrous iron present to the ferric state.

The aluminum tube is employed in the assay for iron in natural waters, because (1) it is light, (2) it can not be easily broken in transportation, like the glass tubes used in the water laboratories, (3) it is provided with a suitable spring for supporting the colored-glass disks, (4) it provides a suitable depth of column of the water for the iron determination, and (5) it is generally used by the hydrographic division in determining the natural colors of waters. The aluminum colorimeter tube thus serves a double purpose, and obviates the necessity of carrying special tubes in the field for the iron assay.

The results reached by this method of determination should be as accurate for practical purposes as those attained by the laboratory method.

\section{CHLORIDES.}

The determination of chlorides in water is significant in twc general lines of investigation. In connection with sanitary analyses, it is in certain parts of the country a valuable index of sewage pollution. In analyses of water for boiler and industrial purposes it is also important, as the chlorides of calcium and magnesium corrode boiler plates.

\section{LABORATORY DETERMINATION.}

With reference to the determination of chlorides from a sanitary -standpoint, the following article by Mr. Daniel D. Jackson, chemist in charge of the Mount Prospect laboratory, department of water supply, gas, and electricity, of New York City, is presented:

Chlorine, a constituent of common salt, is present in nearly all natural raters. Its original sources are mineral salt deposits and finely divided salt spray from the sea. This latter is carried with dust particles by the wind and precipitated with the rain. All salt found in waters not coming from these original snurces comes from domestic drainage, and indicates that the water is at the present time polluted, or was polluted and has since been lurified. By a comparison of the salt contents of any water under examination with the normal chlorine figure for that region, the extent of past or present pollution may be determined.

PHYSIOLOGICAL FUNCTIONS OF COMMON SALT.

Salt always occurs in drainage from animal sources because in all animal economy a certain fairly definite amount of common salt is eaten with the food daily and later expelled from the body in practically the same condition in which it was absorbed. That it plays an important rôle in the blood is indicated by the fact than on an average it constitutes about one-half of the total 
[No. 151.

blood ash. It is also found that normal gastric juice can not be formed without the presence of salt. and that in niany cther secretions of the body its presence is probably a necessity.

\section{SALT AS AN INDICATION OF POLLUTION,}

The amount of salt in a water is a valuable indication of pollution because of the following facts: The animal body expels the same amount of salt that it absorbs; this salt is unchangeable in the soil and is very soluble in water; it must eventually form a part of the drainage and become nixed with the general run-off of the region in which it is expelled. The average arount of salt entering the drainage of any particular district is so constant for each inhabitant that it has been claimed that the number of people living on a drainage area may be determined with a fair degree of accuracy from the average run-off and the excess of chlorine over the normal.a Stearns estimates the chlorine in the run-off of any drainage area not receiving factory waste to be increased about one-tenth of a part per million by every 20 inhabitants per square mile.

\section{SALT IN THE WATERS OF INLAND STATES.}

All salt in natural unpolluted waters farther inland than ohio comes from mineral deposits. The salt winds from the sea have no effect beyond this State, but, unfortunately, west of this state a large proportion of the natural waters are more or less affected by the salt deposits. The underground salt seems to spread over a broad area, and exerts not only a vide but a variable influence over most of the waters. In these inland states, while the "normal chlorine" would be practically zero, the value of the determination of chlorine is in most cases ritiated by the rariable quantity of salt frcm mineral sources. Determinations of chlorine in samples of water taken above and below a city which runs its drainage into the stream examined may give the extent of pollution due to the rity sewage, but the waters so far analyzed in the inland states give indications that the question of normal chlorine does not to any great extent enter into sanitary problems.

\section{SALT IN COAST STATE WATERS.}

On the other hand, the coast State waters are practically unaffected by this mineral salt, and while very extensive deposits exist, especially in the State of New York, they are in narrow pockets and exert an influence over a very limited area. Except in these pockets the mineral salt has apparently been washed into the sea.

It is found that in the coast States the salt in the natural waters which comes from original sources is practically all brought in by the sea winds, and that a certain normal amount is present in the waters of each locality.

The difference in the normal amount in different localitios is due to variations in distance from the seacoast, in the amount of rainfall, in the rate of evaporation, in the amount of protection from ocean winds, and in the direction of the prevailing winds. In spite of the great variety of causes which affect the normal chlorine in natural waters, the normal for any particular region is surprisingly constant.

The chlorine decreases as waters farther and farther inland are tested, so that by connecting with lines on the map localities having the same normal we find that these lines of equal chlorine (isochlors) follow in a general way the

${ }^{a}$ Bept. Massachusetts State Board of Health, 1890, pt. 1, p. 680. 
coast lines, and as they extend inland are still more or less parallel to the coast. The distance of these lines from the coast depends chiefly upon the general direction of the wind and the protecting influences of mountains on the coast or of islands near the mainland.

\section{COLLECTION OW SAMPLES.}

In order to obtain the normal chlorine lines for any State it is first necessary to collect a large number of analyses for chlorine in waters taken at different seasons over the entire area to be covered. It is evident that near the seacoast. where the variations in chlorine within a limited area are greatest, the largest amount of data must be collected. A large number of samples of water taken from surface and ground sources must be obtained. The pond waters usually give the best results, and careful inspection of the drainage area of sucl sources gives a good idea of whether or not the water is sulject to pollution. Samples for analysis should be chosen as far from human habitation as possible.

\section{SOLUTIONS REQUIRED IN THE ANALYSIS OF WATER FOR CHLORINE.}

The following solutions are employed in the analysis of water for chlorine:

Salt solution.--A solution of chemically pure fused salt, containing 1 milligram of chlorine in each cubic centimeter, is made by dissolving 1.648 grams of the fused sodium chloride in 1 liter of distilled water free from chlorine.

Silver-nitrate solution.-Two and one-half grams of crystallized silver nitrate are dissolved in 1 liter of distilled water free from ehlorine. To this solution water or strong silver nitrate is added until by actual titration 10 cubic centimeters of it are equal to 5 cubic centimeters of the standard salt solution. One cubic centimeter of this solution is then equal to 0.5 milligram of chlorine.

Potassium-rhromate solution.- An indicator solution is made by adding 50 grams of potassium chromate to 1 liter of distilled water and then adding sufficient silver-nitrate solution to precipitate all the chlorine present and turn the precipitate slightly reddish. This is allowed to stand, and by filtering or decanting the clear solution is then obtained.

Emulsion of alumina.-This is made by dissolving 125 grams of potassium or ammonium alum in 1 liter of water and precipitating the alumina from boiling solution by ammonia. After precipitation the alumina must be washed free from chlorine, sulphate, and ammonia by successive treatments, settlings, and decantations with cold distilled water.

\section{METHOD OF PROCEDURE IN THE ANALYSIS OF WATER FOR CHLORINE.}

Pour 25 cubic centimeters of the water to be tested into a white porcelain dish. Add about one-half a cubic centimeter of chromate solution and run in standard silver-nitrate solution from a burette until the first faint reddish tint appears. This is more easily noted if for comparison a dish containing the same amount of water and chromate is kept beside the dish in which tho test is made.

If 1 or more cubic centimeters of silver nitrate are necessary to reacl an end point, the test may be made without evaporation, but if less is requirad then evaporate 250 cubic centimeters to 25 cubic centimeters volume before making the test. It may at times be necessary to evaporate more than this if the chlorine present is very close to zero in amount.

It is best to always titrate with 25 cubic centimeters of the water. In this case 0.1 cubic centimeter is subtracted from the results as an indicatcr error.

IRR $151-05-4$ 
If more than this amount is used in titration, subtract 0.1 cubic centimeter for each 25 cubic centimeters of the volume of water titrated.

If $\mathbf{2 5 0}$ cubic centimeters of water are taken, the number of cubic centimeters of silver-nitrate solution used to obtain an end point minus 0.1 cubic centimeter multiplied by 2 , gives the chlorine in parts per million.

Example : 250 cubic centimeters are evaporated to a volume of 25 cubic centimeters and chromate solution added. In the titration 3.5 cuhic centimeters of silver nitrate are used. Then $(3.5-0.1) \times 2=6.8$. The water, then, contains 6.8 parts per million of chlorine.

If the sample is highly colored and very turbid it may be necessary to clarify it by treating it with an emulsion of alumina. This is best accomplished by bringing the water just to the boiling point, and then adding alumina and shaking the emulsion. In a few minutes the clarified water may be decanted. This is allowed to cool and the required amount is measured out for titration.

OBSERVATIONS ON THE USE OF THE NORMAL CHLORINE MAP.

Having drawn a map of this character for any coast State, we are then able to estimate the pollution in any natural water by the amount of chlorine present over the normal. In some instances it is first. necessary to ascertain that the chlorine is not from mineral sources.

It will be seen that the normal chlorine lines are of great practical value, both to the chemist and to the engineer, as they give an inder from which may be estimated the sanitary quality of most waters analyzed within the coast States. The chlorine also furnishes information as to the source of deepseated springs or artesian wells.

While this chlorine in the general run off is in direct propo"tion to the population on a drainage area, provided none of the sewage is carried outside of that area, yet waters in this region may have been pu:ified before reaching the source from which they are collected. The chlorine would still be present and it is necessary to find from other tests whether the pollution is present or past.

It will be noted in Mr. Jackson's discussion that the determination of chlorine for the location of isochlors should be made by very precise laboratory methods. In fact, such precision should be used in all cases in which it is necessary to decide whether or not a water in a country where normal chlorine is significant contains chlorides in an amount which corresponds to or approximates a normal for the country from which the water comes. In general water surveys, however, it is necessary to make such nice distinctions only in rare cases. In the determination of chlorides in a water which is to be used for boiler or industrial purposes this refinement is not necessary, and field methods will generally.suffice.

\section{FIELD DETERMINATION.}

STANDARD SILVER-NITRATE TABLETS.

The Geological Survey proposes to use a method for the rapid determination of chlorides which, from numerous exprriments, seems to meet the conditions in a satisfactory manner. In place of the 


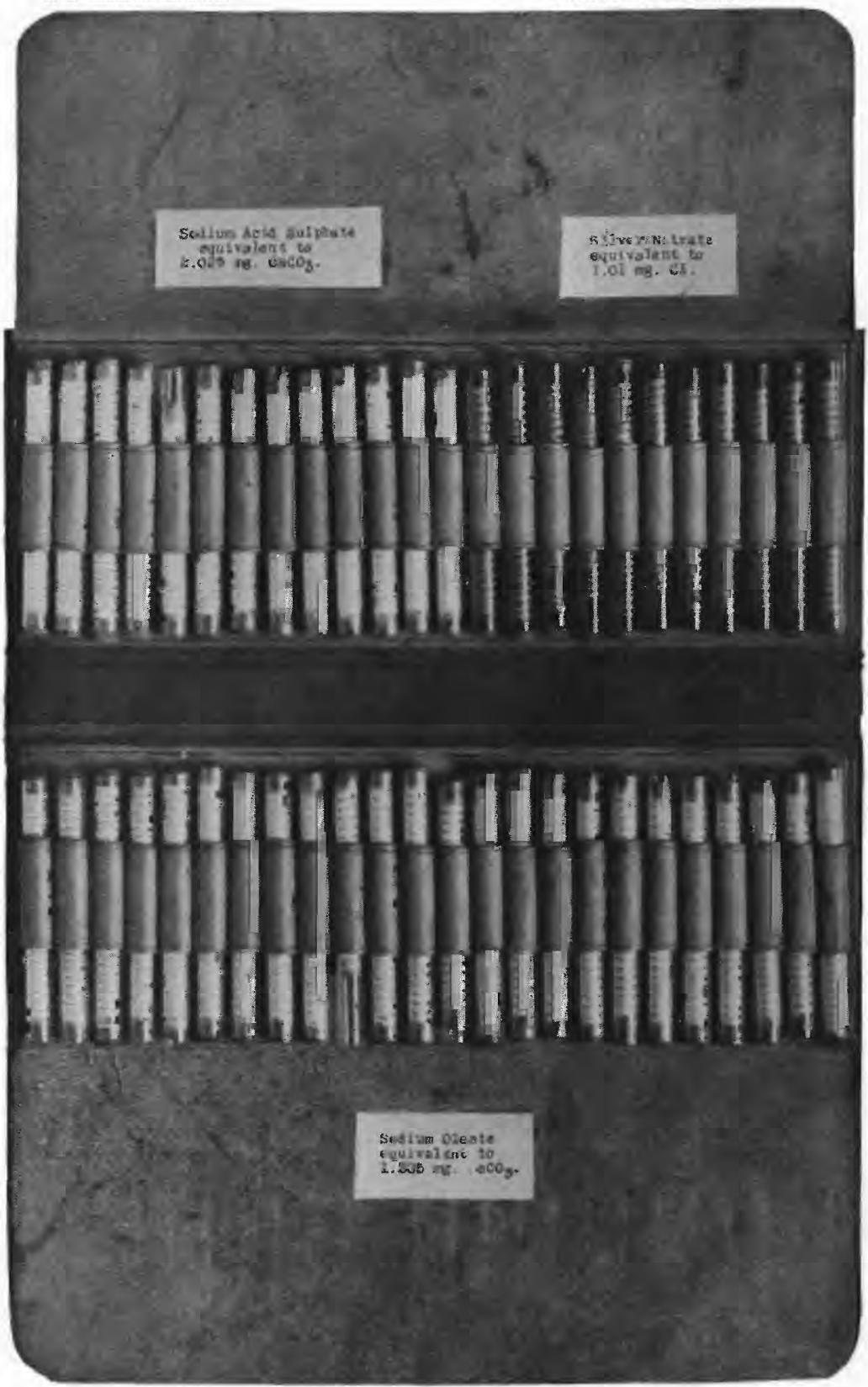

UNITED STATES GEOLOGICAL SURVEY TABLET CASE. 
standard solution of silver nitrate, which must be measured in a burette when applied to a water under examination, there are used tablets of silver nitrate containing a known equivalent of this re'gent. These tablets are packed in tubes and carried in a leather case, the details of which are shown in Pl. III. This method of packing is well designed to avoid mechanical agitation of the tablets, which would result in their loss of active equivalent. The tablets are held securely in place by the stoppers, which are sufficiently small to be pushed through the lumen of the tube as fast as the tablets are used. This maintains a constant pressure against the tablets and prevents their agitation.

The manufacture of stable silver-nitrate tablets proved to be somewhat difficult. A number of pharmaceutical experts who were engaged at various times to prepare them failed to prodice a tablet which was reasonably stable. Those which are now supplied to the Survey are made by the Kremers-Urban Company, of Milwaukee, Wis., and are of superior quality.

In connection with the determination of chlorides it is necassary to carry into the field only a small bottle of potassium-chromate crystals or solution and a heavy glazed porcelain mortar, together with a pestle of approved design. The tablets are dissolved in a mes,sured quantity of water, a small amount of potassium chromate having first been placed in the solution. The end point is indicated by the change in color in the usual way and the number of tablets of known eauivalent indicates the amount of chloride in the water.

This method may be objected to by some chemists because it is generally believed that the results of a chlorine determination made on a water without first evaporating the same are too high. This is apparently true with waters like those of New England, which contain only minute quantities of chlorine, but in the waters of the greater part of the country the chlorides are so high in amount that the error which arises from direct titration is not large enough to be of significance in industrial work.

While the tablets may be manufactured to contain almost. any reasonable amount of silver nitrate, it has been found that the most convenient equivalents for general field use are those of approximately 1 and 10 milligrams of chlorine. In all special cases the strength of tablets should be adjusted to suit conditions. As it is practically impossible to manufacture tablets of the exact equivalent desired, it is necessary to determine the strength of each new supply and to make calculations of all field results accordingly.

The following statement includes various tests of a supply of tablets. Each tablet was made up to contain an equivalent of as near 1 milligram of chlorine as possible. The purposes of the tests were 
to determine the variation in equivalent of single tablets and the combined equivalent of tablets in sets of 5 and 10 , the actual values in milligrams of chlorine being determined by volumetric methods.

Tests to determine variation in silver-nitrate taklets.

[Milligrams.]

\begin{tabular}{|c|c|c|c|c|c|c|c|}
\hline \multicolumn{2}{|c|}{ Single tablets. } & \multicolumn{3}{|c|}{5 tablets. } & \multicolumn{3}{|c|}{10 tablets. } \\
\hline $\begin{array}{l}\text { Equiva- } \\
\text { lent of } \\
1 \text { tablet. }\end{array}$ & $\begin{array}{c}\text { Deviation } \\
\text { from } \\
\text { mean. }\end{array}$ & $\begin{array}{l}\text { Equiva- } \\
\text { lent of } \\
5 \text { tablets. }\end{array}$ & $\begin{array}{l}\text { Mean } \\
\text { equiva- } \\
\text { lent of } 1 \\
\text { tablet. }\end{array}$ & $\begin{array}{c}\text { Deviation } \\
\text { of } 1 \text { tab- } \\
\text { let from } \\
\text { mean. }\end{array}$ & $\begin{array}{l}\text { Equiva- } \\
\text { lent of } 10 \\
\text { tablets. }\end{array}$ & $\mid \begin{array}{c}\text { Meen } \\
\text { equira- } \\
\text { lent of } 1 \\
\text { tabl t. }\end{array}$ & $\begin{array}{l}\text { Deviation } \\
\text { of } 1 \text { tab- } \\
\text { let from } \\
\text { mean. }\end{array}$ \\
\hline 0.96 & -0.045 & 5.060 & 1.012 & -0.015 & 10.24 & 1.024 & +0.0055 \\
\hline .95 & -.055 & 5. 230 & 1.046 & +.019 & 10.15 & 1.015 & -.0035 \\
\hline 1.049 & +.044 & 5.210 & 1.042 & +.015 & 10.17 & 1.017 & -.0015 \\
\hline \multirow[t]{5}{*}{1.062} & +.057 & 5.110 & 1.022 & -.005 & 10.18 & 1.018 & -.0005 \\
\hline & & 5.090 & 1.018 & -.009 & & & \\
\hline & & 5.200 & 1.040 & +.013 & & & \\
\hline & & 5.080 & 1.016 & -.011 & & & \\
\hline & & 5.110 & 1.022 & -.005 & & & \\
\hline Mean. & $\begin{array}{l}\text { Maximum } \\
\text { deviation. }\end{array}$ & \multicolumn{2}{|c|}{ Mean. } & $\begin{array}{l}\text { Maximum } \\
\text { deviation. }\end{array}$ & \multicolumn{2}{|c|}{ Mean. } & $\begin{array}{l}\text { Maximum } \\
\text { deviation }\end{array}$ \\
\hline 1.005 & +0.057 & 5. 211 & 1.027 & +0.019 & 10.185 & 1.018 & +0.0055 \\
\hline
\end{tabular}

It will be seen from the above results that the maximum variation in the equivalent of single tablets is 0.057 milligram of chlorine for each tablet. Therefore, considering the maximum variation shown in the single tablets and allowing, for purposes of illustration, that the maximum error may always be present in a determination, it would be necessary to use 18 tablets in a determination in order to reach an error equivalent to 1 milligram of chlorine. The mean value, however, of the single tablet is thoroughly representative of all the tablets tested, the variations lying above and below the mean value equally. It will be seen, further, that when the tablets are used in larger quantities and the combined equivalents of such quantities are compared, the deviations from the mean are.considergbly less and the maximum deviation is practically negligible. This is shown especially well in the statement of the comparison of the ten tablets. It is therefore apparent that the tablets do not vary by an appreciable amount, and that having established their equivalent by taking the mean of several determinations, such mean can be used in connection with the field determinations of chlorine in natural waters. 


\section{PRACTICAL TESTS WITH TABLET METHOD.}

Three chloride solutions were made up at random, whick, when tested by precise methods, were found to contain $4,280,12,940$, and 1,372 parts of chlorine per million, respectively. These solutions were titrated with tablets, and the end points reached in tha same manner as that used in the field. The results are set forth in the following table:

Tests of silver-nitrate tablets, with solutions of known equivalent.

SOLUTION NO. 1.-CHLORINE, 4,280 PARTS PER MILLION.

\begin{tabular}{|c|c|c|c|c|c|}
\hline $\begin{array}{l}\text { Volume of } \\
\text { solution. }\end{array}$ & $\begin{array}{c}\text { Number of } \\
\text { tablets. }\end{array}$ & $\begin{array}{l}\text { Value of } \\
\text { tablets. }\end{array}$ & $\begin{array}{l}\text { Parts chlo- } \\
\text { rine, tablet } \\
\text { method. }\end{array}$ & $\begin{array}{l}\text { Deviation } \\
\text { from actual } \\
\text { value. }\end{array}$ & $\begin{array}{c}\text { Per cent } \\
\text { deviation. }\end{array}$ \\
\hline c. $c$. & & & & & \\
\hline 22 & 133.0 & 1.052 & 6,350 & $+2,070$ & 48.4 \\
\hline 5 & 21.0 & 1.052 & 4,410 & +130 & 3.04 \\
\hline 5 & 21.0 & 1.052 & 4,410 & +130 & 3.04 \\
\hline 25 & 10.4 & 10.1 & 4,200 & - & 1.87 \\
\hline 95 & 10.0 & 10.1 & 4160 & 120 & 980 \\
\hline & 3.0 & 1.052 & 4,160 & -120 & 2.80 \\
\hline 50 & 20.8 & 10.1 & 4,200 & - & 1.87 \\
\hline \multirow{4}{*}{50} & 20.0 & 10.1 & & & \\
\hline & 5.0 & 1.052 & 4,154 & -126 & 2.44 \\
\hline & 1.0 & .481 & & & \\
\hline & & & & & 15.06 \\
\hline
\end{tabular}

Mean deviation (six results) $=15.06 \div 6=2.51$ per cent.

SOLUTION NO. 2.-CHLORINE 12,940 PARTS PER MILLION.

\begin{tabular}{|c|c|c|c|c|c|}
\hline 26 & 32.25 & 10.1 & 12,510 & -430 & 3.32 \\
\hline 26 & 32.0 & 10.1 & 12,430 & -510 & 3.94 \\
\hline 15 & $\begin{array}{r}19.5 \\
1.0\end{array}$ & $\begin{array}{l}10.1 \\
1.052\end{array}$ & 13,200 & +260 & 2.01 \\
\hline 15 & $\begin{array}{r}18.5 \\
8.0\end{array}$ & $\begin{array}{l}10.1 \\
1.052\end{array}$ & 13,020 & +80 & .62 \\
\hline 5 & 64.0 & 1.052 & 13,470 & +530 & 4.09 \\
\hline & & & & & 13.98 \\
\hline
\end{tabular}

Mean deviation $=13.98 \div 5=2.80$ per cent. 
T'ests of silver-nitrate tablets, with solutions of known equivalent-Continued.

SOLUTION NO. 3.-CHLORINE 1,372 PARTS PER MILLION.

\begin{tabular}{|c|c|c|c|c|c|}
\hline $\begin{array}{l}\text { Volume of } \\
\text { solution. }\end{array}$ & $\begin{array}{l}\text { Number of } \\
\text { tablets. }\end{array}$ & $\begin{array}{l}\text { Value of } \\
\text { tablets. }\end{array}$ & $\begin{array}{l}\text { Parts chlo- } \\
\text { rine, tablet } \\
\text { method. }\end{array}$ & $\begin{array}{l}\text { Deviation } \\
\text { from actual } \\
\text { value. }\end{array}$ & $\begin{array}{r}\text { Per cent } \\
\text { deviation. }\end{array}$ \\
\hline c. $c$. & & & & & \\
\hline 50 & 6.7 & 10.1 & 1,353 & -19 & 1.38 \\
\hline \multirow[t]{3}{*}{50} & 6.0 & 10.1 & \multirow[t]{3}{*}{1,358} & \multirow{3}{*}{-14} & \multirow{3}{*}{1.02} \\
\hline & 7.0 & 1.052 & & & \\
\hline & 6.0 & 10.1 & & & \\
\hline \multirow[t]{2}{*}{50} & 6.0 & 1.052 & \multirow[t]{2}{*}{1,358} & \multirow[t]{2}{*}{-14} & \multirow[t]{2}{*}{1.02} \\
\hline & 2.0 & .481 & & & \\
\hline \multirow{3}{*}{20} & 26.0 & 1.052 & \multirow{3}{*}{1,392} & \multirow{3}{*}{+20} & \multirow{3}{*}{1.46} \\
\hline & 1.0 & .481 & & & \\
\hline & 6.0 & 1.052 & & & \\
\hline \multirow[t]{3}{*}{5} & 1.0 & .481 & \multirow[t]{3}{*}{1,480} & \multirow[t]{3}{*}{+108} & 7.80 \\
\hline & 2.4 & .253 & & & \\
\hline & & & & & 12.27 \\
\hline
\end{tabular}

Mean deviation $=12.27 \div 5=2.45$ per cent.

The first result in the table above set forth is so radically wrong that it is inserted to illustrate a condition which must always be a voided when this method is employed, viz, the use of a large number of tablets. It will be noted that a considerable amount of strong chloride solution was used with tablets of low equivalent, i. e., 1.052 milligrams of chlorine. This made it necessary to use 133 tablets to reach the end point, with a result that is absurd. But 25 and 50 cubic centimeters of the same solution are titrated with the tablets with only a-small error when the tablets of larger equivalent, 10.1 milligrams of chlorine, are used. On the whole, the results shown in the above table are very satisfactory, the error involved in the determinations averaging about 2.5 to 3 per cent, which is well within the limits of field work. Indeed, when the method was designed it was believed that an error of 5 per cent would be as small as could be expected.

A very simple way of testing for small amounts of chlorine is afforded by cutting tablets into quarters with a jackknife. Only ordinary care need be used and the quarters may then be taken for analysis without extreme regard to the selection of large or small pieces. The following account of some experiments performed is submitted :

No. 1. Twenty tablets were cut into quarters. Each quarter should precipitate 0.25 milligram of $\mathrm{Cl}$. To 100 cubic centimeters of water (blank $=0.13$ cubic centimeter) 1 cubic centimeter of $\mathrm{NaCl}$ was 
added, making the actual value of the water $=1.13$ milligrams $\mathrm{Cl}$. Irour quarters gave no end reaction, but five quarters did. This experiment was done fifteen times with the same results. $C$ ne and one-fourth tablets are equivalent to 1.25 milligrams $\mathrm{Cl}$.

No. 2. Twenty more tablets were cut up and added as above, except that 1.1 cubic centimeters of $\mathrm{NaCl}$ were used, making the value of water $=1.23$ milligrams $\mathrm{Cl}$ (blank +0.13 cubic centimeter). Five quarters used in eight out of twelve titrations. This shows a variation in quartering of possibly an equivalent of 0.02 milligram $\mathrm{Cl}$, or 0.2 part per million, an insignificant amount.

No. 3 . Next 1 cubic centimeter of $\mathrm{NaCl}$ was used $(=1.13$ milligrams $\mathrm{Cl}$ ). One whole tablet gave no end reaction, but one, whole tablet+one quarter tablet gave a reaction in every case.

No. 4 . The same was done with 0.9 cubic centimeter $\mathrm{NaCl} \quad(=1.03$ milligrams $\mathrm{Cl}$ ). One tablet, no end reaction; $1 \frac{1}{4}$ tablets, end raction.

No. 5. The same, using 1.2 cubic centimeters $\mathrm{NaCl}\left(=1.3^{\circ}\right.$ milligrams $\mathrm{Cl}$ ). One tablet, no end reaction, $=1$ milligram $\mathrm{Cl} ; 1 \frac{1}{1}$ tablets, no end reaction, $=1.25$ milligrams $\mathrm{Cl} ; 1 \frac{1}{2}$ tablets gave erd reaction, $=1.50$ milligrams $\mathrm{Cl}$.

Nos. 3,4 , and 5 were each done ten times.

The value of these results and their accuracy are shown below:

\begin{tabular}{|r|r|r|}
\hline \multirow{2}{*}{ No. } & \multicolumn{2}{|c|}{ Milligrams chlorine. } \\
\cline { 2 - 3 } & $\begin{array}{c}\text { Actual con- } \\
\text { tent. }\end{array}$ & Found by titration. \\
\hline 1 & 1.13 & 1.25 \\
2 & 1.23 & 8 show 1.25 \\
3 & 1.13 & 4 show 1.50 \\
4 & 1.03 & 1.25 \\
5 & 1.33 & 1.25 \\
& & 1.50 \\
\hline
\end{tabular}

This method comes within 0.25 milligram of the amount of chlorine present, or within 2.5 parts per million of chlorine. This procedure is recommended. If only ordinary care be used in cutting tablets, their value will be within 1 part in a million.

\section{ESTIMATION OF GHLORINE.}

A known amount (about 50 c. c.) of the water to be tested is measured into a glazed porcelain mortar (4 inches diameter) and 5 drops of potassium chromate ( 5 per cent solution) added.

One silver-nitrate tablet is then cut into quarters, using ordinary care to get the quarters equal. Whole tablets are added to the water 


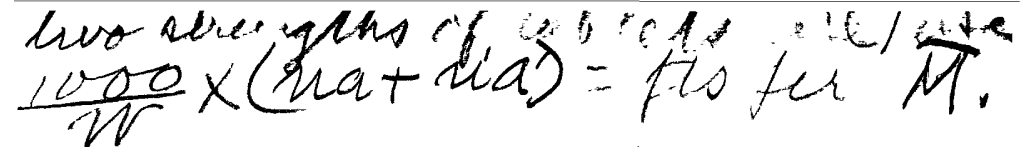

FIELD ASSAY OF WATER:

[No. 151.

till near the end point, when quarter tablets are used. The end point is the appearance of the red color of silver chromate.

$\frac{1,000 \mathrm{nA}}{W}=$ milligrams per liter of chlorine, when $\mathrm{W}=$ cubic centimeters of water used, $\mathbf{n}=$ number of tablets used, and $\mathrm{A}=$ value of one tablet in milligrams of chlorine. Proper allovance should be finally made for the amount of silver nitrate consumed in the end reaction.

Each tube of $\mathrm{AgNO}_{3}$ tablets is marked with its equivalent of chlorine.

NotE.-Silver-nitrate tablets should not be handled witr the fingers nor exposed to sunlight. Keep all tubes well stoppered.

HARDNESS.

GENERAL STATEMENT.

A hard water is popularly recognized as a water vith which it is difficult to obtain a soap lather. Strictly defined, it is that property imparted to water by the carbonates, sulphates, chlorides, and nitrates of calcium and magnesium. Chemical methods for the determination of hardness are not yet well defined; in fact, the whole subject is somewhat chaotic. A method which may be satisfactory for the waters of one part of the United States may be of little value for those of another. Consequently there has developed a rude geographic distribution of methods, each being adapted to the peculiarities of the waters in the regions in which they are used. The result is that comparisons between hardness determinations made in different regions are somewhat uncertain and nearly always unsatisfactory.

The effect of hard water upon the lathering properties of sodium soap-that is, the soap used for laundry and toilet purposes-has been made use of in determining hardness. Indeed, the soap test was the earliest and is still the conmonest of all those employed for this purpose. A standard solution of a pure soap, usually a highgrade castile, is standardized against a solution of celcium chloride, the equivalent of which has been determined in terms of calcium carbonate. The details of this process are too familiar to warrant fur. ther description. Practically, the principal weakness of the test is the determination of the end point, which is not sharply defined. The sodium salts of oleic, palmitic, and stearic acids which compose a pure soap are definite chemical compounds, and their transformation into calcium and magnesium soaps should follow the usual course of chemical change, and therefore the soap test is not merely a test of the soap-consuming power of water, as maintained by some chemists.

In practice the soap test is limited in its usefulness. and its results are modified by many conditions. A few authorities who have made minute studies of the soap method are impressed with its pos- 
sibilities, but the modifications which they suggest are somewhat cumbersome, involve superrefinements, and in the end require so much time that the importance of the results is not commensurate. In those parts of the country where soft waters abound and where it is known that magnesium salts are not abundant the test has great value. Its usefulness is limited in the waters of the Mississippi basin, and it fails entirely when applied to western waters.

\section{FIELD METHOD.}

\section{USE OF SODIUM-OLEATE TABLETS.}

The soap test has been modified for field use by the substitution of tablets of pure sodium oleate for the soap solution. Sodiurn oleate can be obtained in pure form and readily divided in tablets, erch containing a known amount of the reagent. The tablets used by the Geological Survey in field work are made by the Kremers-Urban Company, of Milwaukee, Wis. They are of three grades, "full," "half," and "quarter," or, as they are usually denoted, "F," " $\mathrm{H}$," and "Q," according to their content of 10,5 , or 2.5 milligrams of sodium oleate, respectively.

In using these tablets, 100 cubic centimeters of the water to be tested are placed in a specially designed bottle (Emil Greiner) having a heavy semispherical bottom. Tablets are then added one at a time and dissolved in the water. - This process is greatly hastened by trituration of the tablets in the bottle with a blunt glass rod. After each tablet is dissolved the bottle should be shaken and laid upon its side, and the determination conducted in precisely the same manner as that prescribed in the case of the soap solution. From the number of tablets used and their equivalent the hardness may be determined.

The facility with which this determination may be carried on is largely determined by practice. When first attempted it seems awkward, but after a few trials the operator finds that it can be readily performed. The proper way is to start with the $\mathrm{F}$ tablets until near the end point, then apply the $\mathrm{H}$, and finally the $\mathrm{Q}$ tablets. This-of course may become a method of "trial and error," but the skilled field man will seldom add tablets beyond the end point. The aprearance of the lather at various stages is characteristic and affords a g vide for the operator. In order to show certain characteristic features in the tablet method for the hardness determination the following results of a test made of a supply of tablets are set forth:

TEST OF SODIOM-OLEATE TABLETS.

For a standard of hardness, 0.2 gram of Iceland spar was dissolved in $\mathrm{HCl}$, evaporated to dryness three times in $\mathrm{HCl}$ and twice with water. Finally the residue was dissolved and diluted to one liter 
with redistilled water. Five cubic centimeters of this solution of $\mathrm{CaCl}_{2}$ is equivalent to 1 milligram $\mathrm{CaCO}_{3}$.

The tablets used in the work are of three equivalents, and are designated as follows:

One $\mathbf{F}$ tablet contains an approximate equivalent of 0.0014 gram calcium carbonate.

One $\mathbf{H}$ tablet contains an approximate equivalent of 0.0007 gram calcium carbonate.

One $Q$ tablet contains an approximate equivalent of 0.0073 gram calcium carbonate.

The first test was to determine the amount of sodium-oleate tablet reacted with 100 cubic centimeters distilled water. In the following tabulated statement the sign + denotes a permanent foam or satisfactory end point, while - denotes no end point.

Standardization of sodium-oleate tablets against 100 cubic centimeters distilled water.

\begin{tabular}{|c|c|c|c|c|c|}
\hline $\mathbf{F .}$ & $\mathbf{H .}$ & $\mathbf{Q .}$ & $\mathbf{2 Q .}$ & $\frac{3 \mathbf{Q}}{2}$ & $\mathbf{H +} \mathbf{Q}$ \\
\hline+ & + & - & + & - & + \\
+ & + & - & + & - & + \\
+ & + & - & + & - & + \\
+ & + & - & + & - & + \\
& + & - & + & - & + \\
& + & & & - & \\
\hline
\end{tabular}

Results in the above series of experiments indicate that 100 cubic centimeters distilled water requires about 0.005 grems of sodium oleate.

To reduce this to terms of calcium carbonate experiments were made with 100 cubic centimeters distilled water containing varying amounts of calcium chloride. It was found by repeated trial that where two $\mathrm{H}$ tablets were used it required 3.2 cubic centimeters of the $\mathrm{CaCl}_{2}$ solution in 100 cubic centimeters of distilled water to react exactly. Consequently, as the 100 cubic centimeters distilled water required one $\mathbf{H}$ tablet, the remaining $\mathbf{H}$ tablet was ec uivalent to the $\mathrm{CaCl}_{2}$. Therefore the distilled water is equivalent in th a soap reaction to 3.2 cubic centimeters of $\mathrm{CaCl}_{2}$, or 0.64 milligram $\mathrm{CaCO}_{3}$.

The first experiments in standardizing the tablets vere made with the standard $\mathrm{CaCl}_{2}$ solution diluted with 100 cubic centimeters distilled water against one $F$ tablet, with results as follows: 
Standardization of sodium-oleate tablet $F$.

\begin{tabular}{|c|l|}
\hline $\begin{array}{c}\mathrm{CaCl}_{2} \text { against } \\
1 \mathrm{~F}_{\text {tablet. }}\end{array}$ & \multicolumn{1}{|c|}{ Result. } \\
\hline $\begin{array}{c}\text { c.e. } \\
3.0 \ldots \ldots\end{array}$ & \\
$3.5 \ldots \ldots \ldots$ & Foam. \\
$3.6 \ldots \ldots \ldots$ & Foam. \\
$3.7 \ldots \ldots \ldots$ & Foam. \\
$3.7 \ldots \ldots$ & Foam. \\
$3.7 \ldots \ldots \ldots$ & Foam. \\
$3.7 \ldots \ldots$ & Foam. \\
$3.8 \ldots \ldots$ & Foam. \\
$3.8 \ldots \ldots$ & No foam. \\
$4.0 \ldots \ldots$ & No foam. \\
\hline
\end{tabular}

From the above it appears that one $\mathrm{F}$ tablet is equivalert to 3.7 cubic centimeters $\mathrm{CaCl}_{2}$ solution with 100 cubic centimeters distilled water, or actually equivalent to 6.9 cubic centimeters $(3.7+\overbrace{}^{\complement} .2$ cubic centimeters), which expressed in terms of $\mathrm{CaCO}_{3}$ is equal to 1.38 milligrams.

Using seren $F$ tablets in 100 cubic centimeters distilled water against different amounts of the $\mathrm{CaCl}_{2}$ solution the following results were reported :

\begin{tabular}{|c|l|}
\hline $\begin{array}{c}\mathrm{CaCl}_{2} \text { against } \\
7 \mathrm{~F} \text { tablets. }\end{array}$ & \multicolumn{1}{|c|}{ Result. } \\
\cline { 1 - 2 } c. $c$. & \\
41.7 & Foam. \\
41.5 & Foam. \\
42.5 & Foam. \\
44.9 & Foam. \\
45.0 & Foam. \\
45.9 & No foam. \\
46.0 & No foam. \\
\hline
\end{tabular}

From the above results it appears that the end point is practically reached with 45 cubic centimeters $\mathrm{CaCl}_{2}$ solution. With the amount for 100 cubic centimeters distilled water added, seven taklets are therefore equivalent to 48.2 cubic centimeters $\mathrm{CaCl}_{2}$, or 9.64 milligrams $\mathrm{CaCO}_{3}$. This allows for one tablet an equivalent of 1.37 milligrams $\mathrm{CaCO}_{3}$, which agrees with the previous determinations within the limit of experimental error. 
Experiments were made with various combinations of tablets as follows:

\begin{tabular}{|c|c|l|}
\hline $\mathrm{CaCl}_{2 .}$ & $\begin{array}{c}\text { Tablets (number } \\
\text { and value). }\end{array}$ & \multicolumn{1}{|c|}{ Result. } \\
\cline { 1 - 3 } c.. & & No foam. \\
3.2 & $4 \mathrm{Q}$ & Foam. \\
3.2 & $5 \mathrm{Q}$ & Foam. \\
3.0 & $5 \mathrm{Q}$ & Foam. \\
3.0 & $5 \mathrm{Q}$ & Foam. \\
2.8 & $4 \mathrm{Q}$ & Foam. \\
2.9 & $4 \mathrm{Q}$ & Foam. \\
45.0 & $7 \mathrm{~F}$ & No foam. \\
45.9 & $7 \mathrm{~F}$ & Foam. \\
45.9 & $7 \mathrm{~F}+1 \mathrm{Q}$ & No foam. \\
45.0 & $14 \mathrm{H}$ & Foam. \\
45.0 & $15 \mathrm{H}$ & Foam. \\
45.0 & $6 \mathrm{~F}+2 \mathrm{H}$ & Foam. \\
45.0 & $6 \mathrm{~F}+2 \mathrm{H}$ & \\
\hline
\end{tabular}

Analyzing the results above given we have:

1.

\begin{tabular}{|c|c|l|}
\hline $\begin{array}{c}\text { CaOl } \\
\text { distilled c. c. } \\
\text { water. }\end{array}$ & $\begin{array}{c}\text { Tablets } \\
\text { (number and } \\
\text { value). }\end{array}$ & Result. \\
\hline c.c. & & \\
3.2 & $4 \mathrm{Q}$ & No foam. \\
3.2 & $5 \mathrm{Q}$ & Foam. \\
3.0 & $5 \mathrm{Q}$ & Foam. \\
2.8 & $4 \mathrm{Q}$ & Foam. \\
2.9 & $4 \mathrm{Q}$ & Foam. \\
\hline
\end{tabular}

Therefore four $\mathrm{Q}$ tablets are equivalent to an amo"nt of $\mathrm{CaCO}_{3}$ lying between 1.28 milligrams and 1.22 milligrams, or one $\mathrm{Q}$ tablet to an amount lying between 0.32 and 0.30 . Using either as the value, the error will not be significant. 0.31 milligram is probably the most accurate factor.

2.

\begin{tabular}{|c|c|l|}
\hline $\begin{array}{c}\text { CaCl }+100 \text { c. c. } \\
\text { distilled } \\
\text { water. }\end{array}$ & $\begin{array}{c}\text { Tablets } \\
\text { (number and } \\
\text { value). }\end{array}$ & \multicolumn{1}{|c|}{ Result. } \\
\hline c.c. & & \\
45.0 & $7 \mathrm{~F}$ & Foam. \\
45.9 & $7 \mathrm{~F}$ & No foam. \\
45.9 & $7 \mathrm{~F}+1 \mathrm{Q}$ & Foam. \\
\hline
\end{tabular}


Therefore seven $\mathrm{F}$ tablets are equivalent to an amount of $\mathrm{CaCO}_{3}$ lying between 9.82 and 9.64 milligrams, or one tablet to an gmount lying between 1.40 and 1.38 milligrams. The error introduced if either 1.40 or 1.38 is used as a factor will be less than $\frac{Q}{7}$ and therefore insignificant.

3.

\begin{tabular}{|c|c|l|}
\hline $\begin{array}{c}\mathrm{CaCl}_{2}+100 \mathrm{c.} \mathrm{c} \\
\text { distilled } \\
\text { water. }\end{array}$ & $\begin{array}{c}\text { Tablets } \\
\text { (number and } \\
\text { value). }\end{array}$ & \multicolumn{1}{|c|}{ Result. } \\
\hline c. $e$. & & \\
45 & $14 \mathrm{H}$ & No foam. \\
45 & $15 \mathrm{H}$ & Foam. \\
45 & $6 \mathrm{~F}+2 \mathrm{H}$ & Foam. \\
\hline
\end{tabular}

Therefore the equivalent of 9.64 milligrams $\mathrm{CaCO}_{3}$ lies between the value of 14 and $15 \mathrm{H}$ tablets, or one tablet is equivalent to an amount of $\mathrm{CaCO}_{3}$ between 0.69 and 0.64 milligram. But from the third experiment it is seen that two $\mathrm{H}$ tablets are equivalent to 1.36 milligrams $(9.64-[6 \times 1.38])$, or one tablet to 0.68 milligram.

\section{ESTIMATION OF HARDNESS.}

The directions for using these tablets should be followed absolutely. The end-point foam should be permanent for at least five minutes, the bottle lying upon its side. The smallest number of tablet: possible should be used; for example, if the hardness of a water is 120 parts per million on direct titration without correction, the best procedure assuming the given value of the tablets used would be as follows:

Milligran's $\mathrm{CaCO}_{3}$.

1 tablets equivalent to

$1 \mathrm{H}$ tablet equivalent to

$1 \mathrm{Q}$ taplet equivalent to - 31

Total _- 12.03

Subtracting 0.64 milligram $\mathrm{CaCO}_{2}$ for distilled water-_._._. 64

Hardness expressed by tablets____

Or in parts per million

In this case the error would be equivalent to 0.03 milligrams $\mathrm{CaCO}_{3}$, an amount unimportant in practical work.

The end point can be approached in the manner above described after the operator has had a short experience with the method. The comparative permanence of the preliminary foam pellicles which do not remain unbroken for the entire five minutes is a guide.

*If the total hardness of the rater rxoeeds 150 parts per mililon, this method has the same inaccuracies as the ordinary laboratory method in which a solution of soap is used. 


\section{HARDENING CONSTITUENTS.}

CLASSES.

It is customary to distinguish between temporary and permanent hardness. Temporary hardness is due to the carbonates (and bicarbonates) of calcium and magnesium. Calcium and nagnesium carbonates are not readily soluble in water unless accompanied by carbon dioxide. Under such circumstances it is supposed that the carbonates become bicarbonates, although the bicarbonates of these two elements have never been isolated. When waters containing calcium and magnesium bicarbonates are boiled the carbon dioxide is driven off and the normal carbonates of calcium and magnesium ar? precipitated. Therefore, the properties which they impart to the water are designated temporary hardness. Permanent hardness, on the other hand, is that property which is imparted to waters by the sulphates, chlorides, and nitrates of the alkali earths. They are not precipitated by ordinary boiling, and therefore their effects are regarded as permanent. The usual method of determining temporary and permanent hardness by the soap test consists in making the test on a sample of water before boiling, and another on a similar sample after boiling; the difference in the two results representing the temporary hardness.

Temporary and permanent hardness are often expressed as alkalinity and incrusting constituents, respectively, and it is common to see, even in analytical reports of well-informed chemists, the expression "alkalinity or temporary hardness." This expression is misleading. It is approximately correct when the waters of New England and certain other portions of the country ore referred to, but as a general statement concerning the majority of waters nothing could be more inaccurate. There are abundant instances in which waters are alkaline to an extraordinary degree, and yet are widely known as soft waters, giving little or no reaction with the soap test. The alkalinity in such cases is due to the carbonates of sodium and potassium, which, while they impart a truly alkaline reaction, have no hardening effect. The majority of the waters of the United States contain alkali carbonates, and therefore any interpretation of alkalinity as being equivalent to temporary hardness with such waters is erroneous.

If the alkalinity found in a water is the result of the carbonates of the alkali-earth elements, its industrial significance is considerably different from that of the carbonates of the alkalies. For example, calcium carbonate forms soft scale when $u^{\text {sed }}$ in boilers, while sodium carbonate forms no scale, but presents a much less important difficulty, that of foaming. If, however, a water containing calcium carbonate were used for irrigation purposes, it 
would not damage crops unless it were present in extremely high proportions-higher, in fact, than it is almost ever found in nature. On the other hand, a small amount of sodium carbonate is destructive to crops. It is as desirable to know whether the sulphates and chlorides which are found in the water are of the alkali earths or the alkalies, for they present variations in usefulness with reference to industries similar to those above described in the case of tra carbonates.

It has been the endeavor of the Geological Survey to so modify the methods by which the various determinations of the hardening constituents of water may be made that they can be used in the field. These methods are set forth in subsequent pages. They do not include all of the determinations desirable for some classes of work, but sufficient to allow of a very comprehensive interpretation concerning the quality of any water under investigation.

\section{CARBONaTES.}

The determination of alkalinity or carbonates is a simple volumetric process. It requires only a standard solution of ar acid, preferably a mineral acid, with accurate means for measuring the same, and a proper indicator solution. On account of the carbon dioxide set free by the determination, methyl orange is the indicator in commonest use. The objections already cited to carrying stendard solutions and burettes in the field led to an attempt to adopt an acid which could be preserved in tablet form. Many organic acids were tried, but is was found that they were either too weak to afford a definite end point or were of so deliquescent a character that they could not be made to form stable tablets. It was finally decided to adopt the use of sodium acid sulphate. Tablets made from this reagent are easily regulated in equivalent and are of an extremely stable nature. The results which can be procured tr rough their use are very satisfactory.

TESTS OF SODIUM ACID-SULPHATE TABLETS.

For use in titrating against sodium acid-sulphate tablets a fiftieth normal solution of sodium carbonate was made, in which each cubic centimeter equals 1.06 milligram $\mathrm{NaCO}_{3}$. Six sets of five sodium acidsulphate tablets each were then dissolved in 50 cubic centimeters of distilled water and each solution was titrated with the strndard sodium carbonate. The results of these titrations are shown in the following table: 
Standardization of sodium acid-sulphate tablets.

\begin{tabular}{|c|c|c|}
\hline $\mathrm{NaHSO}_{4}$ & $\mathrm{Na}_{2} \mathrm{CO}_{3}$. & Value of 1 tablet. \\
\cline { 1 - 2 }$c . c$. & $c . c$. & $\mathrm{MgCaCO}_{3}$. \\
10.60 & 2.15 & 2.03 \\
10.15 & 2.05 & 2.02 \\
10.85 & 2.20 & 2.03 \\
10.30 & 2.10 & 2.04 \\
10.10 & 2.05 & 2.03 \\
10.10 & 2.05 & 2.03 \\
\hline
\end{tabular}

Assuming these final reactions,

$$
\begin{gathered}
\mathrm{Na}_{2} \mathrm{CO}_{3}+2 \mathrm{NaHSO}_{4}=2 \mathrm{Na}_{2} \mathrm{SO}_{4}+\mathrm{H}_{2} \mathrm{O}+\mathrm{CO}_{2}, \\
\text { and } \mathrm{CaCO}_{3}+2 \mathrm{NaHSO}_{4}=\mathrm{CaSO}_{4}+\mathrm{H}_{2} \mathrm{O}+\mathrm{CO}_{2}+\mathrm{Na}_{2} \mathrm{SO}_{4} \text {, }
\end{gathered}
$$

then for the expression of the value of our tablet in milligrams of $\mathrm{CaCO}_{3}$ we have the following proportion:

$$
\frac{\mathrm{Na}_{2} \mathrm{CO}_{3}}{\mathrm{CaCO}_{3}}=\frac{106}{100} .
$$

The experiments above described were made with solutions of the acid-sulphate tablets, and the results show the constancy of the reaction between the normal carbonate and the sulphate. They do not show, however, the variations which would occur in the practical use of the tablets applied directly to the alkaline solutiod, as would be done in the field. Therefore the following tests are submitted to show the deviations which may arise in successive tablets or successive sets of tablets. The tablets used were marked "Lot 715, sodium acid-sulphate equivalent to 1.995 milligrams calcium carbonate." These tablets had been in stock for several months, had ro eeived some rough handling, and were in poor condition. In fact, they represented the most unfavorable conditions that might be supposed to cccur in connection with the field use of tablets, and the variations which are shown may be accepted as the extreme veriations which are likely to occur in common use.

In testing and standardizing the sodium acid-sulphate tablets normal solutions of sulphuric acid and sodium carbonate were used. Tests were made as follows:

Solutions of unknown strength of sodium carbonate were made up and the alkalinity was determined volumetrically with standard sulphuric acid solution. Following this, determinatiors of the same unknown solutions were made with the tablets. Varying amounts of the solution were used, with a corresponding variation in the number of tablets. 
Comparative determinations of alkalinity in carbonate solutions with stchdard sulphuric-acid and sodium acid-sulphiate tablets.

CARbONATE SOLUtion No. 1.-ALKalinity, 5,764 PARTS PER MILlion IN TERMS OF CALCIUM CARBONATE.

\begin{tabular}{|c|c|c|c|c|}
\hline $\begin{array}{l}\text { Amount of } \\
\text { solution. }\end{array}$ & $\begin{array}{c}\text { Number of } \\
\text { tablets. }\end{array}$ & $\begin{array}{c}\text { Parts per } \\
\text { million. }\end{array}$ & $\begin{array}{l}\text { Deviation } \\
\text { in parts per } \\
\text { million. }\end{array}$ & $\begin{array}{l}\text { Per cent de } \\
\text { viation. }\end{array}$ \\
\hline c.c. & & & & \\
\hline 1.9 & 5 & 5,225 & -539 & 9.3 \\
\hline 3.5 & 10 & 5,674 & -90 & 1.56 \\
\hline 7.0 & 20 & 5,674 & -90 & 1.56 \\
\hline 11.0 & 32 & $5 r a 6$ & 38 & 66 \\
\hline 10.5 & 30 & 5,720 & -38 & .00 \\
\hline 17.5 & 50 & 5,674 & -90 & 1.56 \\
\hline 46.5 & 135 & 5. 767 & +3 & .05 \\
\hline
\end{tabular}

CARbonate SOLUTION No. 2.-ALKalinity, 2,312 PARTS PER MILlion IN TERMS OF CALCIUM CARBONATE.

\begin{tabular}{|r|r|r|r|l|}
\hline 4.5 & 5 & 2,207 & -105 & 4.55 \\
10.0 & 12 & 2,383 & +71 & 3.1 \\
15.0 & $\begin{array}{r}18 \\
21.0\end{array}$ & 25 & & \\
19.0 & 2,384 & +72 & 3.1 \\
25.5 & .30 & & & \\
25.0 & 30 & 2,359 & +47 & 2.0 \\
51.0 & 60 & & & \\
50.5 & 59 & 2,328 & +14 & .61 \\
\hline
\end{tabular}

The figures of the above tables show that when a large number of tablets are used to determine alkalinity the results are more nearly correct than when a few are used. This is especially noticeable in the first entries in the two tables, where the small amount of the alkaline solution used requires only five tablets. The error in each of these cases is larger than is permissible even in field work. In the remainder of the tests, however, the variation is not sufficiently great to be appreciable, especially in the weaker carbonate solutions, where it is shown that the use of a larger nimber of tablets involves a minimum error. This suggests that in connection with the field determination of carbonates it is advisable, wherever waters of a low alkalinity are tested, to use a large arount of the water in order that a large number of tablets can. be used to neutralize the alkalinity, and thereby avoid the error arising from the variation which occurs in the single tablets. 
Measure 100 cubic centimeters of water to be tested into a glazed porcelain mortar (4 inches diameter). Add two drops methylorange indicator. Add $\mathrm{NaHSO}_{4}$ tablets till an acid reaction is reached. Then add some of the original water that is being tested, drop by drop, till an alkaline reaction is exactly reached. Measure the liquid in the mortar and to the amount of the reading add 1 cubic centimeter for the wetted interior of the dish. The following formula is convenient for use in making calculations of alkalinity:

$$
\frac{1,000 \mathrm{n} \mathrm{A}}{\mathrm{W}} \text { equals milligram per liter of } \mathrm{CaCO}_{3} \text {. }
$$

When $\mathrm{W}$ equals eubic centimeter of water used;

$n$ equals number tablets used;

A equals value of 1 tablet in milligrams of $\mathrm{CaCO}_{3}$.

Each consignment of tablets is marked with its value in equivalent of $\mathrm{CaCO}_{3}$.

NORMAL AND ACID CARBONATES.

It is nearly always of value to determine the proportion of normal and acid carbonates in a water, for it affords a fairly good index to the character of the base with which the carbon dioxide is united. It is a generally accepted idea that the carbonates of the alkalineearth metals are, when in solution in water, in the form of bicarbonates. For the general purposes of field work it mey be considered that all bicarbonates occurring in natural waters are alkaline-earth carbonates and may conveniently be calculated as $\mathrm{CaCO}_{3}$. All normal carbonates, on the other hand, must be alkali carbonates; conveniently calculated as $\mathrm{Na}_{2} \mathrm{CO}_{3}$. This generalization is not uniformly true, especially in certain classes of wester' 1 waters. It has been plainly shown, by the work of Messrs. Frank J*. Cameron and Lyman J. Briggs, of the Bureau of Soils, United States Department of Agriculture, that there is considerable complexity in the occurrence and equilibrium of carbonates and bicarbonates in waters. There are, however, few practical water problems oncurring outside of the alkali-desert regions in which the interpretation of bicarbonates as alkaline-earth carbonates and normal carbonates as alkali carbonates would lead to erroneous results. The fold men of the United States Geological Survey are therefore inst:ucted to report bicarbonates as $\mathrm{CaCO}_{3}$ and normal carbonates as $\mathrm{Na}_{2} \mathrm{CO}_{3}$, in the absence of data which will allow of other interpretations.

The method of determining carbonates and bicarbonates in aqueous $\left\{\begin{array}{l}\text { solution is discussed by Mr. Frank K. Cameron, chemist of the Bureau } \\ \text { of Soils, in Bulletin No. } 18 \text { of the United States Depertment of Agri- } \\ \text { culture, Bureau of Soils, pages 77-89. The method depends upon the }\end{array}\right.$ 
fact that while phenolphthalein reacts with the normal carbonates of the alkali and alkaline-earth metals and not with the bicarbonates, methyl orange reacts with either. The water under investigation is titráted with a standard solution of potassium acid sulphate, using phenolphthalein as an indicator, the first end point being the complete disappearance of the red color. Methyl orange is then added to the solution, and the titration is continued with the same standard until a pink acid reaction is obtained. The amount of standard solution used to reach the first end point is a meas'ure of the amount of normal carbonates, while the total amount used in securing both end points, less twice that for the first end poirt, is a measure of the bicarbonates.

The reaction taking place before and up to the total neutalization of the phenolphthalein is a conversion of carbonates into bicarbonates and can probably be expressed as follows:

$$
2 \mathrm{KHSO}_{4}+2 \mathrm{Na}_{2} \mathrm{CO}_{3}=\mathrm{Na}_{2} \mathrm{SO}_{4}+\mathrm{K}_{2} \mathrm{SO}_{4}+2 \mathrm{NaHCO}_{3}
$$

or

$$
2 \mathrm{KHSO}_{4}+2 \mathrm{MgCO}_{3}=\mathrm{MgSO}_{4}+\mathrm{K}_{2} \mathrm{SO}_{4}+\mathrm{Mg}\left(\mathrm{HCO}_{3}\right)_{2} \text {. }
$$

The neutralization of bicarbonates probably takes place in this manner:

or

$$
2 \mathrm{KHSO}_{4}+2 \mathrm{NaHCO}_{3}=\mathrm{Na}_{2} \mathrm{SO}_{4}+\mathrm{K}_{2} \mathrm{SO}_{4}+2 \mathrm{H}_{2} \mathrm{Q}+2 \mathrm{CO}_{2}
$$

$$
2 \mathrm{KHSO}_{4}+\mathrm{Mg}\left(\mathrm{HCO}_{3}\right)_{2}=\mathrm{MgSO}_{4}+\mathrm{K}_{2} \mathrm{SO}_{4}+2 \mathrm{H}_{2} \mathrm{O}+2 \mathrm{CO}_{2} \text {. }
$$

It is evident that when the end point with phenolphthalein has been reached there remains as a product of the first reaction, ir addition to the bicarbonates originally present, an amount of bicarbonates equal in reacting power to the reaction shown by the phenolphthalein. In other words, double the amount of potassium acid sulphate required to convert the carbonates to bicarbonates, and so destroy the color of the phenolphthalein, is necessary to completely neutralize the normal carbonates as indicated by methyl orange. This must be taken into consideration in computing the results from the titration.

Inasmuch as the reactions taking place when sodium acid sulphate is used must be similar to those with the use of potassium acid sulphate, there is no reason to believe that the tablets now in use in this division may not be substituted for the standard solution suggested by. Mr. Cameron. Experiments have been made to determine the accuracy of the results obtainable and are discussed in the following paragraphs.

An unknown amount of thoroughly fused Kahlbaum's sodium bicarbonate was dissolved in distilled water that had previousl to been boiled to drive out carbonic acid. Twenty-five cubic centimeters of 
[No. 151.

this solution, which should contain only sodium carbonate, was tested by adding phenolphthalein, triturating and dissolving standard tablets of sodium acid sulphate till decolorized, adding methyl orange, and continuing the trituration until the methyl-orange end point was reached. Another equal portion of the solution was tested by adding methyl orange alone and dissolving tablets until the end point was reached. The results in the two cases were as follows:

1. Necessary for phenolphthalein end point

Excess necessary for methyl-orange end point________________- 9 tablets.

2. Total necessary for methyl-orange end point

Two solutions were then made, one similar to the first, of sodium carbonate in boiled distilled water, the other of supposedly pure Kahlbaum's sodium bicarbonate in distilled water, also boiled. These were tested by solution of tablets, using first phenolphthalein and then methyl orange as an indicator, as in the first case.

Sodium carbonate solution 25 cubic centimeters.

Necessary for phenolphthalein end point 27 tablets.

Necessary excess for methyl-orange end point 27 tablets.

Sodium bicarbonate solution 2 - cubic sentimeters.

Necessary for phenolphthalein end point 15 tablets.

Necessary excess for methyl-orange end point 57 tablets.

It is evident that the solution of bicarbonate was impure, 30 tablets out of a total of 72 being required for the neutralization of the normal carbonate. A mixture of these two solutions was then made, as follows:

Sodium carbonate solution

Cubic centimeters.

Solution containing bicarbonate 100

Distilled water (boiled)

It is evident that the number of tablets required by this solution, if the method is reliable, will be equal to one-fourth of the sum of all the tablets used to neutralize the two original solutior s, 25 cubic centimeters being taken in each case. This should be true, not only of the whole determination, but of each part. Tests made of the mixture resulted as follows:

Necessary for phenolphthalein end point $10 \frac{1}{2}$ tablets.

Necessary excess for methyl-orange end point 21 tablets.

Inspection of these figures and comparison with those preceding indicate that, in so far as it is possible to judge under the conditions, the method is accurate and reliable.

To make the determination, measure a convenient quantity of the water to be tested into a porcelain mortar and add 4 drops of phenolphthalein ( 1 per cent). Triturate the standard $\mathrm{NaHSO}_{4}$ tablets in the mortar, one at a time, until the color disappears. Note the 
zumber of tablets and then add 4 drops of methyl orange ( 1 per cent). Continue the titration with the tablets until the orange color $\mathrm{cf}$ the solution changes to a faint pink. Then note the total numbar of tablets used in both titrations. The equivalent of the sodium acidsulphate tablets is usually given in terms of calcium carbonate. Therefore the amount of bicarbonates in the water may be calcu"ated directly from this valuation. In order to calculate the normal carbonates as $\mathrm{Na}_{2} \mathrm{CO}_{3}$, it will be necessary to multiply the valuation of the sodium-sulphate tablets given by 1.06 , the conversion factor of $\mathrm{TaCO}_{3}$ to $\mathrm{Na}_{2} \mathrm{CO}_{3}$.

For computation of the normal carbonates in parts per million, double the number of tablets used for the decolorization of phenolvhthalein, multiply by the equivalent of each tablet in milligrams $\mathrm{Na}_{2} \mathrm{CO}_{3}$. Then multiply this product by 1,000 and divide the whole by the number of cubic centimeters of the sample tested. To find bicarjonates in parts per million, subtract from the total number of tablets "ssed in the two titrations twice the number required for the phenolshthalein end point and multiply this difference by the equivalent of ach tablet in terms of calcium carbonate. Then multiply this prodict by 1,000 and divide by the number of cubic centimeters of water tested.

For the convenient expression of the above in formulas, assure the following symbols:

$\mathrm{A}=$ equivalent of $\mathrm{NaHSO}_{4}$ tablets in terms of milligrams of $\mathrm{C} \varepsilon \mathrm{CO}_{3}$. $\mathrm{B}=$ equivalent of $\mathrm{NaHSO}_{4}$ tablets in terms of milligrams of $\mathrm{Na}_{2} \mathrm{CO}_{3}$.

The conversion factor being 1.06 , we have

$$
\mathrm{A}=\frac{\mathrm{B}}{1.06} \text { or } \mathrm{B}=1.06 \mathrm{~A} \text {. }
$$

$\mathbf{n}=$ number of tablets used to reach first or phenolphthalein end point: $\gamma=$ number of tablets used to reach second or methyl-orange end point. $\mathrm{W}=$ amount in cubic centimeters of water tested.

Then for the determination of normal carbonates we have the formula

$$
\frac{2,000 \mathrm{nB}}{\mathrm{W}}
$$

ind for the determination of bicarbonates

$$
\frac{1,000(N-2 n) A}{W} \text {. }
$$

The results of the two above equations will be the expression of parts ver million.

\section{SULPHATES:}

Water generally contains either one or more of the sulphates of sodium, potassium, calcium, magnesium, and iron. If present in ninute amounts the effect of any or all of them is negligible, knt if 
they appear in large proportions they do damage in every branch of science or industry in which it is necessary to use vater. Calcium, magnesium, and iron sulphates damage boilers, textiles, soaps, malt liquors, paper, and many other manufactured prod ıcts, while they render water undesirable for domestic purposes. The sulphates of sodium and potassium are troublesome in boilers, and damage crops when water containing large amounts is used fo" irrigation. A knowledge of the amount of sulphates in a water is of great importance.

The determination of sulphates, as it is usually forformed in the laboratory, is a slow, laborious, and expensive process. A field method has, however, been devised by which the sulphates can be determined in a few minutes and with a degree of accuracy sufficient for all practical purposes. The determination involves the use of the Jackson turbidimeter, described on previous pages. In the fol lowing paragraphs the determination of sulphates is described by the originator of the method, Mr. Daniel D. Jackson:

\section{DETERMINATION BY TURBIDIMETER.}

Knowledge of the amount of sulphates in a water to be used for industrial purposes is especially important. The scale which is most trorblesome to remove from boilers is produced by the precipitation of sulphate of lime. If the amount of sulphate is considerable the determination of lime may be made by the turbidimeter with a fair degree of accuracy. The method is as follows:

To 100 cubic centimeters of water to be tested add 1 cubic centimeter of hydro( chloric acid (1-1) and 1 gram of solid barium-chloride crystals. If the amount of sulphate is low, 200 or 300 cubic centimeters of water must be treated in order to fill the longer tube employed. In this case add 1 cubic centimeter of acid and 1 gram of barium chloride for each 100 cubic centimeters of water taken.

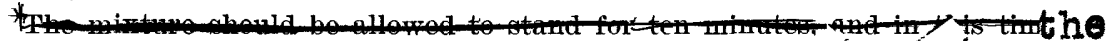

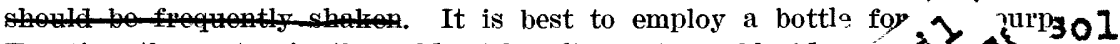
Treating the water in the cold with solid barium chloride
sulphate to be precipitated in a finely divided state, and $t y$ may then be read by either the candle or the electric two

In the lower part of the tube the end point is $\mathrm{ta}^{\mathbf{}}$ light disappears. This is a higher reading the cross disappears. Higher up in the tube ther ${ }^{\circ}$ end point is the disappearance of the sb is obtained, remove the glass tube and bottom of the meniscus in reading) tảble to obtain the parts per milv

The readings of these inst' by the amount of light us $\rho$ little or no error in $t r$ of different natura point is not to but to the $\mathrm{co}^{\circ} \mathrm{C}$ sion. ored $r$
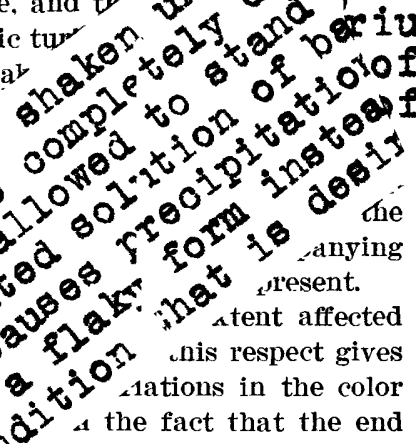
In using the electric turbidimeter, if the image becomes perceptibly dim the battery is replaced by a fresh one, but if the analyst is careful to keep the light. turned off except when actually making readings the batteries will last for a considerable period of time. Fresh electric bulbs and batteries may be obtained from the Howard Electric Novelty Company, 221-227 Canal street, New York City, or 183 Lake street, Chictgo. If any parts of the instrument are lost or broken they may be replaced by Baker \& Fox, 83 Schermerhorn street, Brooklyn, N. Y.

Table for converting readings in depths by the turbidimeter into parts per million or grains per gallon of sulphate.

\begin{tabular}{|c|c|c|c|c|c|}
\hline $\begin{array}{l}\text { Reading in } \\
\text { centime- } \\
\text { ters. }\end{array}$ & $\begin{array}{l}\text { Parts per } \\
\text { milliion, } \\
\mathrm{SO}_{3 .}\end{array}$ & $\begin{array}{c}\text { Grains per } \\
\text { United } \\
\text { States gal- } \\
\text { lon, } \text { SO }_{3 .}\end{array}$ & $\begin{array}{c}\text { Reading in } \\
\text { centime- } \\
\text { ters. }\end{array}$ & $\begin{array}{c}\text { Parts per } \\
\text { million, } \\
\mathrm{SO}_{3} .\end{array}$ & $\begin{array}{l}\text { Grains per } \\
\text { United } \\
\text { States gal- } \\
\text { lon, SO- }\end{array}$ \\
\hline 1.0 & 522 & 30.5 & 3.9 & 144 & 8.4 \\
\hline 1.1 & 478 & 28.0 & 4.0 & 140 & 8.2 \\
\hline 1.2 & 442 & 25.8 & 4.1 & 137 & 8.0 \\
\hline 1.3 & 410 & 24.0 & 4.2 & 133 & 7.8 \\
\hline 1.4 & 383 & 22.4 & 4.3 & 131 & 7.7 \\
\hline 1.5 & 359 & 21.0 & 4.4 & 128 & 7.5 \\
\hline 1.6 & 338 & 19.8 & 、 4.5 & 125 & 7.3 \\
\hline 1.7 & 319 & 18.6 & 4.6 & 122 & 7.1 \\
\hline 1.8 & 302 & 17.7 & 4.7 & 119 & 7.0 \\
\hline 1.9 & 287 & 16.8 & 4.8 & 117 & 6.8 \\
\hline 2.0 & 273 & 16.0 & 4.9 & 115 & 6.7 \\
\hline 2.1 & 261 & 15.3 & 5.0 & 113 & 6.6 \\
\hline 2.2 & 250 & 14.6 & 5.1 & 110 & 6.4 \\
\hline 2.3 & 239 & 14.0 & 5.2 & 108 & 6.3 \\
\hline 2.4 & 230 & 13.5 & 5.3 & 106 & 6.2 \\
\hline 2.5 & 221 & 12.9 & 5.4 & 104 & 6.0 \\
\hline 2.6 & 213 & 12.4 & 5.5 & 103 & 6.0 \\
\hline 2.7 & 205 & 12.0 & 5.6 & 101 & 5.9 \\
\hline 2.8 & 198 & 11.6 & 5.7 & 99 & 5.8 \\
\hline 2.9 & 191 & 11.2 & 5.8 & 97 & 5.7 \\
\hline 3.0 & 185 & 10.8 & 5.9 & 96 & 5.6 \\
\hline 3.1 & 179 & 10.5 & 6.0 & 94 & 5.5 \\
\hline 3.2 & 173 & 10.1 & 6.1 & 93 & 5.4 \\
\hline 3.3 & 168 & 9.8 & 6.2 & 91 & 5.3 \\
\hline 3.4 & 164 & 9.6 & 6.3 & 90 & 5.2 \\
\hline 3.5 & 159 & 9.3 & 6.4 & 88 & 5.1 \\
\hline 3.6 & 155 & 9.1 & 6.5 & 87 & 5.1 \\
\hline 3.7 & 151 & 8.8 & 6.6 & 86 & 5.0 \\
\hline 3.8 & 147 & 8.6 & 6.7 & 84 & 4.9 \\
\hline
\end{tabular}


Table for converting readings in depths by the turbidimeter into parts per million or grains per gallon of sulphate-Continued.

\begin{tabular}{|c|c|c|c|c|c|}
\hline $\begin{array}{l}\text { Reading in } \\
\text { centime- } \\
\text { ters. }\end{array}$ & $\begin{array}{c}\text { Parts per } \\
\text { million, } \\
\mathrm{SO}_{3} .\end{array}$ & $\begin{array}{l}\text { Grains per } \\
\text { United } \\
\text { States gal- } \\
\text { lon, } \mathrm{SO}_{3} .\end{array}$ & $\begin{array}{c}\text { Reading in } \\
\text { centime- } \\
\text { ters. }\end{array}$ & $\begin{array}{l}\text { Parts per } \\
\text { million, } \\
\mathrm{SO}_{3} .\end{array}$ & $\begin{array}{c}\text { Grains per } \\
\text { United } \\
\text { States gal- } \\
\text { lon, } \mathrm{SO}_{3} .\end{array}$ \\
\hline 6.8 & 83 & 4.9 & 12.4 & 46 & 2.7 \\
\hline 6.9 & 82 & 4.8 & 12.6 & 45 & 2.6 \\
\hline 7.0 & 81 & 4.8 & 12.8 & 44 & 2.6 \\
\hline 7.1 & 80 & 4.7 & 13.0 & 43 & 2.5 \\
\hline 7.2 & 79 & 4.7 & 13.5 & 42 & 2.5 \\
\hline 7.3 & 78 & 4.6 & 14.0 & 41 & 2.4 \\
\hline 7.4 & 77 & 4.5 & 14.5 & 39 & 2.3 \\
\hline 7.5 & 76 & 4.4 & 15.0 & 38 & 2.3 \\
\hline 7.6 & 75 & 4.4 & 15.5 & 37 & 2.2 \\
\hline 7.7 & 74 & 4.3 & 16.0 & 36 & 2.1 \\
\hline 7.8 & 73 & 4.3 & 16.5 & 35 & 2.0 \\
\hline 7.9 & 72 & 4.2 & 17.0 & 34 & 2.0 \\
\hline 8.0 & 71 & 4.2 & 17.5 & 33 & 1.9 \\
\hline 8.1 & 70 & 4.1 & 18.0 & 32 & 1.9 \\
\hline 8.2 & 69 & 4.0 & 18.5 & 31 & 1.8 \\
\hline 8.3 & 68 & 4.0 & 19.0 & 30 & 1.8 \\
\hline 8.5 & 67 & 3.9 & 20.0 & 29 & 1.7 \\
\hline 8.6 & 66 & 3.9 & 21.0 & 28 & 1.7 \\
\hline 8.7 & 65 & 3.8 & 22.0 & 27 & 1.6 \\
\hline 8.8 & 64 & 3.8 & 22.5 & 26 & 1.6 \\
\hline 9.0 & 63 & 3.7 & 23.0 & 25 & 1.5 \\
\hline 9.1 & 62 & 3.7 & 24.0 & 24 & 1.4 \\
\hline 9.3 & 61 & 3.6 & 25.0 & 23 & 1.3 \\
\hline 9.5 & 60 & 3.6 & 26.5 & 22 & 1.3 \\
\hline 9.7 & 59 & 3.5 & 28.0 & 21 & 1.2 \\
\hline 9.8 & 58 & 3.4 & 29.0 & 20 & 1.2 \\
\hline 10.0 & 57 & 3.3 & 31.0 & 19 & 1.1 \\
\hline 10.2 & 56 & 3.3 & 33.0 & 18 & 1.1 \\
\hline 10.4 & 55 & 3.2 & 35.0 & 17 & 1.0 \\
\hline 10.6 & 54 & 3.2 & 37.5 & 16 & 1.0 \\
\hline 10.8 & 53 & 3.1 & 40.0 & 15 & .9 \\
\hline 11.0 & 52 & 3.1 & 43.0 & 14 & .9 \\
\hline 11.2 & 51 & 3.0 & 46.5 & 13 & .8 \\
\hline 11.4 & 50 & 3.0 & 50.0 & - 12 & .7 \\
\hline 11.6 & 49 & 2.9 & 55.5 & 11 & .6 \\
\hline 11.8 & 48 & 2.8 & 62.0 & 10 & .6 \\
\hline 12.0 & 47 & 2.7 & 68.0 & 9 & .5 \\
\hline
\end{tabular}


1. The same care should be taken as in measuring turbidity to have the turbidimeter in good running order. 2. Always shake the solution until all the barium chloride is dissolved. Otherwise a flaky precipitate may be obtained. 3. Since the barium-sulphate precipitate is very heavy, the solution should be mixed frequently by pouring and shaking while readings are being made. 4 . Only sufficient hydrochloric acid should be added to make the water acid.

\section{- calciuar.*}

The determination of calcium is made by means of the turbidimeter, the method being similar to that described in the chapter on sulphates. It is the Iatest, and therefore the least known, of all the determinations here described. While the results which have been reached by this method appear to be satisfactory, no particular plan has yet been offered to determine certain necessary facts with reference to the behavior of precipitated calcium oxalate. The method depends upon the turbidity produced by the precipitation of calcium oxalate upon the addition of ammonium oxalate to the water under investigation. Whether or not the variations which occur in the character of this precipitate under different conditions are sufficient to affect appreciably the degree of turbidity produced is a matter which is yet to receive attention.

The test is made in the following manner: To 100 cubic centimeters of the water to be tested add a. few drops of ammonium hycroxide, $\mathrm{NH}_{4} \mathrm{OH}$. The amount added should be barely sufficient to impart to the water a perceptible ammoniacal odor. Then add crystals of ammonium oxalate. The amount of crystals to be added depends, of course, upon the amount of lime in the water. As this is yet undetermined, care should be taken to add an excess of ammonium oxalate. Mix thoroughly and allow the solution to stand for ten or fifteen minutes. Then determine the turbidity with the Jackson turbidimeter precisely as described in previous pages in the case of sulphates. and state the amount of calcium according to the table given below.

The treatment above described will precipitate materials othor than calcium, but they are usually in so small a proportion in natural waters that they do not often give trouble. The most frequent complication arises from the precipitation of magnesium on the addition of ammonia. If the precipitate is sufficient in amount to materially affect the degree of turbidity it should be filtered before the addition of ammonium oxalate.

*It has been found by two or three hundred field tests and by laboratory experimentation sinoe this Bulletin was published that this method for oaloium is not reliablo, the results frequently being as much as $59 \%$ from the correct ones. This trouble is due to vexiation in the size of the caloium oxalate orystals under different conditions of ooncentraticn, temp- 
The table given below for the determination of calcium is less satisfactory than that for sulphates, and it will probably be found that corrections must be made as future experience dictates.

Table for determining calcium with Jackson's turbicimeter.

\begin{tabular}{|c|c|c|c|c|c|c|c|}
\hline $\begin{array}{c}\text { Reading } \\
\text { in cen- } \\
\text { timeters. }\end{array}$ & $\begin{array}{c}\text { Parts per } \\
\text { million. }\end{array}$ & $\begin{array}{c}\text { Reading } \\
\text { in cen- } \\
\text { timeters. }\end{array}$ & $\begin{array}{c}\text { Parts per } \\
\text { million. }\end{array}$ & $\begin{array}{c}\text { Reading } \\
\text { in cen- } \\
\text { timeters. }\end{array}$ & $\begin{array}{c}\text { Parts per } \\
\text { million. }\end{array}$ & $\begin{array}{l}\text { Reaciing } \\
\text { in cen- } \\
\text { timeters. }\end{array}$ & $\begin{array}{l}\text { Parts per } \\
\text { million. }\end{array}$ \\
\hline 1.0 & 1,150 & 4.0 & 167 & 7.0 & 80 & 10.0 & 53 \\
\hline 1.1 & 1,000 & 4.1 & 162 & 7.1 & 78 & 10.2 & 52 \\
\hline 1.2 & 890 & 4.2 & 156 & 7.2 & 77 & 10.4 & 51 \\
\hline 1.3 & 795 & 4.3 & 151 & 7.3 & 76 & $1 \mathrm{C} .6$ & 50 \\
\hline 1.4 & 715 & 4.4 & 146 & 7.4 & 74 & $1 C .8$ & 49 \\
\hline 1.5 & 650 & 4.5 & 142 & 7.5 & 73 & 11.0 & 48 \\
\hline 1.6 & 595 & 4.6 & 137 & 7.6 & 72 & 11.2 & 47 \\
\hline 1.7 & 550 & 4.7 & 133 & 7.7 & 71 & 11.4 & 46 \\
\hline 1.8 & 505 & 4.8 & 130 & 7.8 & 70 & 11.7 & 45 \\
\hline 1.9 & 470 & 4.9 & 126 & 7.9 & 69 & 11.9 & 44 \\
\hline 2.0 & 435 & 5.0 & 123 & 8.0 & 68 & 12.2 & 43 \\
\hline 2.1 & 410 & 5.1 & 119 & 8.1 & 67 & 12.4 & 42 \\
\hline 2.2 & 380 & 5.2 & 116 & 8.2 & 66 & 12.7 & 41 \\
\hline 2.3 & 360 & 5.3 & 113 & 8.3 & 65 & 13.0 & 40 \\
\hline 2.4 & 340 & 5.4 & 110 & 8.4 & 64 & 13.3 & 39 \\
\hline 2.5 & 320 & 5.5 & 107 & $\cdot 8.5$ & 64 & 13.7 & 38 \\
\hline 2.6 & 305 & 5.6 & 105 & 8.6 & 63 & 14.0 & 37 \\
\hline 2.7 & 288 & 5.7 & 102 & 8.7 & 62 & 14.4 & 36 \\
\hline 2.8 & 274 & 5.8 & 100 & 8.8 & 61 & 14.8 & 35 \\
\hline 2.9 & 261 & 5.9 & 98 & 8.9 & 60 & 15.3 & 34 \\
\hline 3.0 & 248 & 6.0 & 96 & 9.0 & 60 & 15.7 & 33 \\
\hline 3.1 & 238 & 6.1 & 94 & 9.1 & 59 & 16.2 & 32 \\
\hline 3.2 & 228 & 6.2 & 92 & 9.2 & 58 & 16.7 & 31 \\
\hline 3.3 & 218 & 6.3 & 90 & 9.3 & 57 & 17.3 & 30 \\
\hline 3.4 & 209 & 6.4 & 88 & 9.4 & 57 & 17.9 & 29 \\
\hline 3.5 & 200 & 6.5 & 87 & 9.5 & 56 & 18.5 & 28 \\
\hline 3.6 & 194 & 6.6 & 85 & 9.6 & 55 & 19.2 & 27 \\
\hline 3.7 & 186 & 6.7 & 84 & 9.7 & 55 & 20.0 & 26 \\
\hline 3.8 & 179 & 6.8 & $8 \%$ & 9.8 & 54 & 21.7 & 24 \\
\hline 3.9 & 173 & 6.9 & 81 & 9.9 & 54 & 22.7 & 23 \\
\hline
\end{tabular}

INSTRUMENTS AND REAGENTS.

The field case (see Pl. IV) contains the instruments and reagents described below:

1. A Berkfeld army filter for removing suspended matter from water under investigation. The porous stone in this filter should 


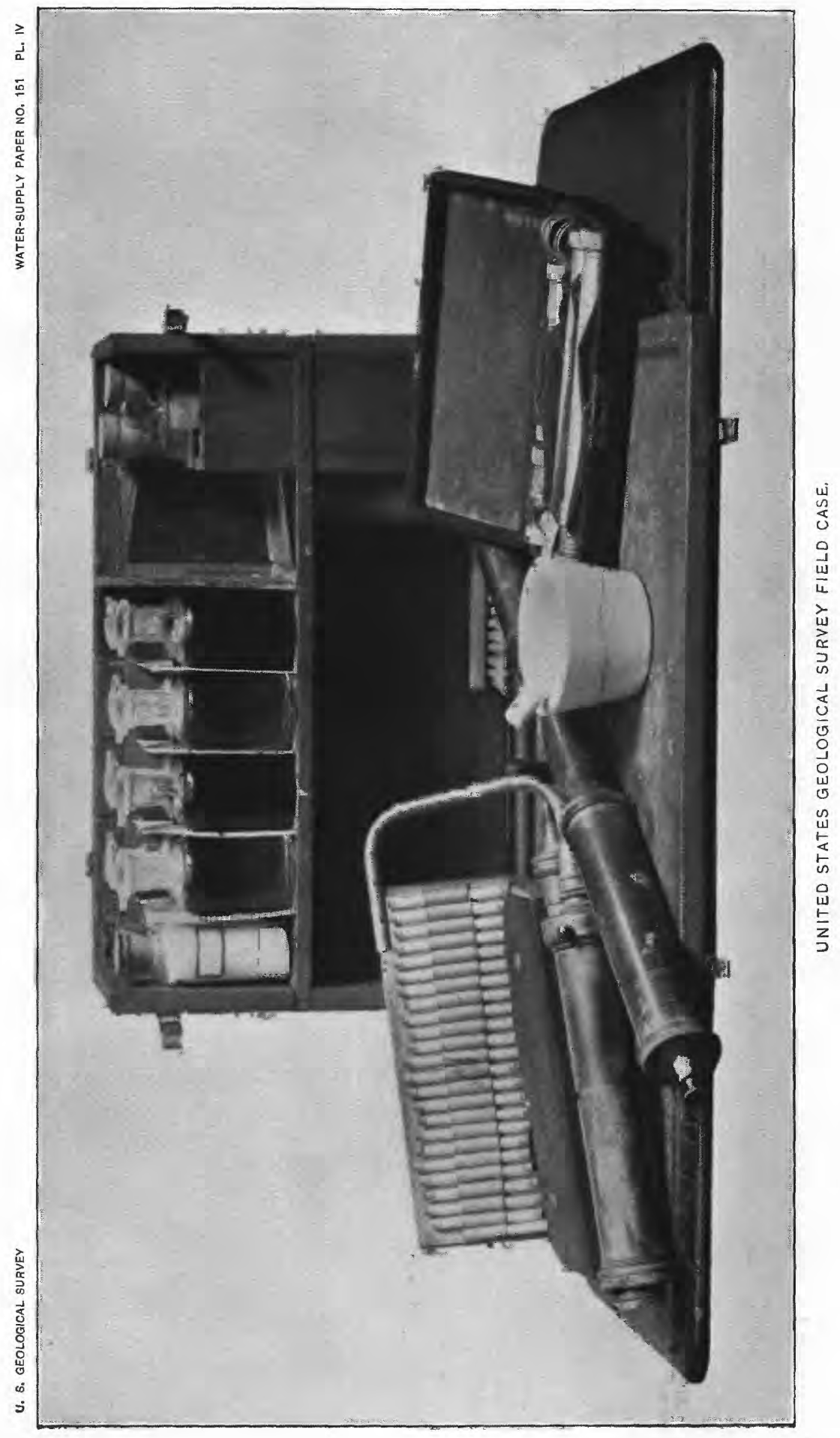


be removed from the tube frequently and thoroughly cleansed with the small stiff brush provided for this purpose. If it is desired to secure sterile water, or if the only water available is known to be polluted and a supply for drinking purposes is desired, the filter stone should be boiled or baked frequently. Watch the filter stone closely for cracks and imperfections. When water is pumped through the filter, care should be taken that the suction end does not rest on sand or mud; such materials, if drawn into the buckets of th pump, are troublesome and materially shorten the term of usefulness of the filter.

2. One or more leather cases containing tubes of reagent tablets. The equivalent of each tablet of the various reagents should be noted on a slip pasted upon the inside of the case.

The tablets are packed in tubes to prevent mechanical agitation. This is highly important, because if the tablets are loosely packed a loss of active chemical reagent is inevitable. Tablets which show signs of extraordinary wear should be rejected. In using a tube one of the cork stoppers should be removed and the tablets poured out as needed. When the end point is reached the cork should be replaced and the stoppers in the opposite end of the tube should be pushed through the lumen until the tablets remaining in the tube are projected against the opposite stopper, thus holding them serurely.

Sodium-oleate tablets are packed in unmarked transparent glass tubes. Two grades of silver-nitrate tablets are usually issued. The tubes containing tablets of the higher equivalent have a cross etched on the glass, while those with the lower equivalent are etched with a single transverse line. The sodium acid-sulphate tablets are packed in transparent glass tubes, upon each of which is etched the symbol $\mathrm{NaHSO}_{4}$.

3. One case containing four aluminum tubes for natural color and for iron determinations. There will also be provided brown-glass disks for the color determination or red-glass ones for the iron, or both. The equivalent of each disk in terms of parts per million is engraved on the aluminum rim.

4. One Jackson candle or electric turbidimeter with two graduated cylinders for same. An extra electric bulb, a ground-glass disk, a brass cross disk, a standard English candle, and a dry battery will be provided with each turbidimeter. The field observer should not use any dry battery which has been in his possession over sixty days, irrespective of the intensity of the light produced by it. Candles other than the standard English spern should not be used.

The candle turbidimeter should be used in preference to the electric whenever possible, as the former is the more steady instrument and insures uniformity of results. If, however, it is necessary to make 
determinations in exposed places when the wind is blowing, the electric turbidimeter must be ụsed, as the slightest flickering of the candle flame will introduce errors in the determinations. Whenever possible, water samples should be carried to a convenient shelter and assayed.

5. Seven special dropping bottles containing the following reagents: Concentrated nitric acid $\left(\mathrm{HNO}_{3}\right)$; concentrated hydrochloric acid $(\mathrm{HCl})$; concentrated anmonium hydroxide $\left(\mathrm{NH}_{4} \mathrm{OH}\right)$; two per cent solution of potassium sulphocyanide (KCNS) ; five per cent solution of potassium chromate $\left(\mathrm{K}_{2} \mathrm{CrO}_{4}\right)$; one per cent solution of phenolphthalein; one-tenth per cent solution of methyl orange.

Care should be taken to close the stoppers in these dropping bottles where they are packed in the cases.

6. Two salt-mouth bottles containing pure crystals of barium chloride and ammonium oxalate.

All bottles containing chemicals have etched labels, except the indicators, the colors and odors of. which are sufficiert for identification.

7. One heavily glazed porcelain mortar and pestle.

8. One round-bottom glass bottle, with glass pestle, for hardness determination.

9. One small horn spoon for handling crystals noted in section 6 .

10. One 5 c. c. pipette in case for general use in measuring small amounts of liquid.

11. One centigrade thermometer in brass case.

12. One loose-leaf notebook. This notebook is made up of printed cards, with every alternate leaf a blank.

* Instead of carrying concentrated hydrochlori acid in the case it is advisable to carry 1-1 ao The concentrated acid corrodes the inside of the case badiy and by its fumes contaminates the pot sium chromate indicator used in the chlorine det mination. This is not so likely to happen if di ted acid is carried. 


\section{IN D EX.}

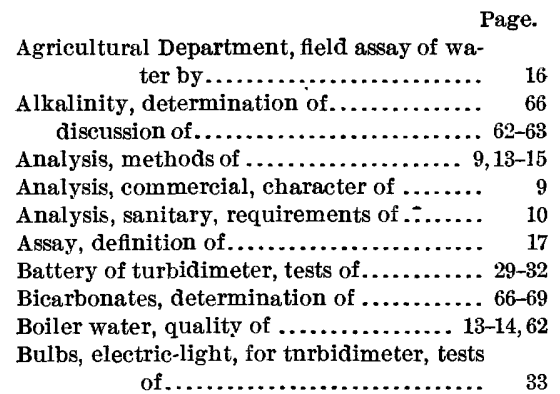

Calcium, determination of ............... 73-74

Calcium carbonate, effect of ............ 62-63

Candle turbidimeter, description of....... 27

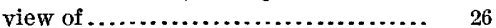

Carbonates, determination of ........... 63-69 Chemicals, list of, in Survey outfit ........ 74-76

Chlorine, determination of, in field .... 48, 50-56 determination of, in laboratory ....... 47-50 occurrence of....................... 47-49

Chlorine maps, construction and use of.... 50

Clarke, F. W., on water analysis .......... 14

Color of water, definition of............. 41-42 determination of . ..................44-46 - tubes and disks for, plate show-

$$
\text { ing }
$$
standards of

Conservatism, abuse of. 46

Crenothrix, growth of.................. 45

Electric turbidimeter, description of...... 27-28 view of $\ldots \ldots \ldots \ldots \ldots \ldots \ldots \ldots \ldots \ldots \ldots .28$

Filtration, determination of turbidity by.. $\quad 19$ Fuller, George W., on nitrogen determination.......................11-13

Geological Survey, field case of, description of.................... 16-17, 74-76 field case of, view of.

tablet case, description of .

Gila River, A rizona, turbidity of ........ 50

Glass plate for turbidimeter, tests of ........ 33

Hardening constituents, classes of ......... 62-63

Hardness, permanent, definition of ........ 62 determination of . . ................ 70-74

Hardness, temporary, definition of......... 62 determination of ................... 63-69

Hardness, total, definition of............. 56-61 determination of . . . . . . . . . . . . .

Hazen, Allen, turbidity rod of .

23

Hypothetical combinations, unreliability

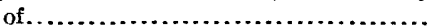

Incrusting constituents, determination of, accuracy of................. 13-14

Instruments, list of, in Survey outfit ...... . 74-76
Page.

Iron in water, determination of..........45-47 effects of ............................ 45

Isochlors, determination of ............. 50

Jackson, D. D., on chlorides ............. 47-50

on sulphates....................... $70-78$

on turbidity ........................ $\quad 22$

Jackson's turbidimeters, description of ..... 26-28

tests of ............................ 29-41

views of $\ldots \ldots \ldots \ldots \ldots \ldots \ldots \ldots \ldots \ldots . .26,28$

Macomb, 1ll., well at, water of, analyses of. 14

Massachusetts, water survey in ........... 15

Nitrites, determination of, futility $o^{\text {f }}$, in sanitary analysis ............. 11-13

Ohio, water survey in ................... 15

Oxygen, relation of nitrites and .......... 13

Platinum-cobalt method of color determi-

nation ..................... 42-43

modification of, in field ............... 43-44

use of................................ 44-45

Reagents, list of, in Survey outfit ......... 74-76

Richards, Ellen H., field assay outfit of .... 16

Sewage, analysis of, interpretation of..... 11-13

Silica, standard solution of, preparation of. 33-34

Silver-nitrate tablets, manufacture and use

of.................... 50-51,55-56

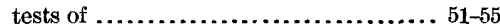

Soap test for hardness, use of............. 56

Sodium acid sulphate tablets, tests of ..... 63-65 use of.............................. 66

Sodium carbonate, effect of ............. 62-63

Sodium-oleate tablets, tests of............ 57-61 use of .............................. 57,61

Sulphates, determination of............. 70-73

Tablet case, description of ............... $\quad 75$

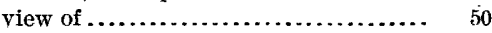

Turbidimeters, Jackson's, description of ... 26-28

tests of ........................... $29-41$

use of....................... 27-28, 70-71

views of $\ldots \ldots \ldots \ldots \ldots \ldots \ldots \ldots \ldots \ldots \ldots \ldots \ldots \ldots \ldots \ldots \ldots, 26$

Turbidity, curves of, figures showing ...... 38,39

definition of ........................ 18

determination of, methods of ......... 18-41

Geological Survey rod for determina-

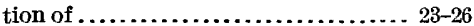

relation of volume of suspended matter and ........................ 19-20

relation of weight of suspended matter and ...................... 20-22 standard of . ................... 22-23,33-40

Turbidity coefficient, definition of ......... 19-20

Water, analysis of, interpretations of ..... 13-15

methods of ....................... $9-10$

Water surveys, chemical, slowness of ...... 15-16

Water surveys, field, speed of ............ 16

Weston, R. S., on turbidity.............. 19-20

Whipple, G. C., on turbidity scale ....... 22-23 


\section{PUBLICATIONS OF UNITED STATES GEOLOGICAL SURVEY.}

[Water-Supply Paper No. 151.]

The serial publications of the United States Geological Survey consist of (1) Annual Reports, (2) Monographs, (3) Professional Papers, (4) Bulletins, (5) Mireral Resources, (6) Water-Supply and Irrigation Papers, (7) Topographic Atlas of United States-folios and separate sheets thereof, (8) Geologic Atlas of United States-folios thereof. The classes numbered 2,7 , and 8 are sold at cost of publication; the others are distributed free. A circular giving complete lists may be had on application.

Most of the above publications may be obtained or consulted in the follow:ng ways:

1. A limited number are delivered to the Director of the Survey, from wl om they may be obtained, free of charge (except classes 2,7 , and 8 ), on application.

2. A certain number are allotted to every member of Congress, from wl om they may be obtained, free of charge, on application.

3. Other copies are deposited with the Superintendent of Documents, Washington, D. C., from whom they may be had at practically cost.

4. Copies of all Government publications are furnished to the principal public libraries in the large cities throughout the United States, where they may be consulted by those interested.

The Professional Papers, Bulletins, and Water-Supply Papers treat of a variety of subjects, and the total number issued is large. They have therefore been classified into the following series: A, Economic geology; B, Descriptive geology; C, Systematic geology and paleontology; D, Petrography and mineralogy; E, Chemistry and physics; F, Geography; G, Miscellaneous; H, Forestry; I, Irrigation; J, Water storage; K, Pumping water; L, Quality of water; M, General hydrographic investigations; N, Water power; O, Underground waters; P, Hydrographic progress reports. This paper is the eleventh in Series $\mathrm{L}$, the complete list of which follows. ( $\mathrm{PP}=$ Professional Paper; $\mathrm{B}=$ Bulletin; $\mathrm{WS}=$ Water-Supply Paper.)

\section{SERIES L-QUAIITY OF WATER.}

WS 3. Sewage irrigation, by G. W. Rafter. 1897. 100 pp., 4 pls. (Out of stock.)

WS 22. Sewage irrigation, Pt. II, by G. W. Rafter. 1899. 100 pp., 7 pls. (Out of stock.)

WS 72. Sewage pollution near New York City, by M. O. Leighton. 1902 . 75 pp., 8 pls.

WS 76. Flow of rivers near New York City, by H. A. Pressey. 1903. 108 pp, 13 pls.

WS 79. Normal and polluted waters in northeastern United States, by M. O. Leighton. 1903.192 pp., 15 pls.

WS 103. Review of the laws forbilding pollution of inland waters in the United States, by E. B. Goodell. 1904. $120 \mathrm{pp}$.

WS 108. Quality of water in the Susquehanna River drainage basin, by M. o. Leighton, with an introductory chapter on physiographic features, by G. B. Hollister. 1904.76 pr., 4 pls.

WS 113. Strawboard and oil wastes, by R. L. Sackett and Isaiah Bowman. 1905. 52 pp., 4 pls.

WS 121. Preliminary report on the pollution of Lake Champlain, by M. O. Leighton. 1905. 119 pp., 13 pls.

WS 144. The normal distribution of chlorine in the natural waters of New York and New England, by D. D. Jackson. 1905 . 31 pp., 5 pls.

WS 151. Field assay of water, by M. O. Leighton. 1905.77 pp., 4 pls.

Correspondence should be addressed to

\section{The Director,}

United States Ghological Survey, WASHINGTOIT. D. C.

OCTOBER, 1905. 


\section{LIBRARY CATALOGUE SLIPS.}

[Mount each slip upon a separate card, placing the subject at the top of the second slip. The name of the series should not be repeated on the series card, but the additional numbers should be added, as received, to the first entry.]

Leighton, Marshall O[ra] $1874-$

. . Field assay of water, by Marshall O. Leighton. Washington, Gov't print. off., I905.

77 , iii p. illus., IV pl., diagrs. $23^{\mathrm{cm}}$. (U. S. Geological survey. Watersupply and irrigation paper no. 151)

Subject series: I, Quality of water, 11.

1. Water-analysis.

\section{Leighton, Marshall O [ra] I874-}

. . Field assay of water, by Marshall O. Leighton. Washington, Gov't print. off., I905.

77, iii p. illus., IV pl., diagrs. $23^{\mathrm{cm}}$. (U. S. Geological survey. Watersupply and irrigation paper no. 151)

Subject series: L; Quality of water, 11.

1. Water-analysis:

U. S. Geological survey.

Water-supply and irrigation papers.

no. I5I. Leighton, M. O. Field assay of water. 1905.

\footnotetext{
U. S. Dept. of the Interior.
see also
U. S. Geological survey.

U. S. Dept. of the Interi
see also
U. S. Geological survey.

IRR $151-05-6$ 


\section{Corrections.}

RID-MLF

Page 46, Iine 36: In place of the words "and allowed to stand 10 minutes, " read and comparison made imediately.

Page 61, Estimation of Hardness: If the total hardness of the water exceeds 150 parts per million, this method has the same inaccuracies as the ordinary laboratory mothod in which a solution of soap is used.

Page 70, line 30: In place of "The mixtume should be allowed to stand for 10 minutes and in this time it should be frequently shaken," read The mixture should be shaken until the barium onlorIde crystals are completely disolved, for it the mixture is allowed to stand without shaking the concentrated solution of barium ch oride in the bottom causes precipitation of the barium 8ulphate In a Ilaky lorm Instead of the semIcolloldal condition that 18 desired.

Page 73, Calolum: It has been found by 2 or 3 hundre Ilold tests and by laboratory experimentation since this Bulletin was publishod that this method for calcium is not reliable, the results frequentiy being as much as $50 \%$ from the correct one This trouble is due to variation in the size of the calcium oxalate crystals under diforent conditions of concentration, temperature and the presence of other salts.

Page 76, line 6:Instead of carrying conoentrated hydrochloric aoid in the case it is advisable to carry 1-1 acid. The concentrated acld corrodes the inside of the case badly ano by its fumes contaminates the potassium chrorate indisator used in the chlorine determinaticn. This is not so $11 \mathrm{kely}$ to happen if diluted acjd is used.

It is preferable to make determinations with the turbidimeter in the dark, or at any rate, not in direct sunlight, because the outside light affects the eye, so that lower readings than the correct ones are obtained. The batteries in the electric turbidimeter will last with moderate use from 30 to 60 days in a moderately humid olimate. In arid regions, they dry up so fast that it is preferable thou $h$ not so converient to use the candle turbi- 